\title{
Synthesis, Structures and Reactions of Aluminum(I) and Aluminum(III) Compounds
}

\author{
Dissertation \\ zur Erlangung des Doktorgrades \\ der Mathematisch-Naturwissenschaftlichen Fakultäten \\ der Georg-August-Universität zu Göttingen
}

vorgelegt von

Ying Peng

aus Ji'an

(China)

Göttingen 2004 


\section{7}

Referent:

Korreferent:

Tag der mündlichen Prüfung: $\quad$ 03.11.2004
Prof. Dr. Dr. h.c. mult. H. W. Roesky Prof. Dr. J. Magull 
Dedicated to my parents and my husband for their love and affection 


\section{Acknowledgement}

The work described in this doctoral thesis has been carried out under the guidance and supervision of Professor Dr. Dr. h. c. mult. H. W. Roesky at the Institut für Anorganische Chemie der Georg-August-Universität in Göttingen between December 2000 and October 2004.

My sincere thanks and gratitude are to

\section{Professor Dr. Dr. h. c. mult. H. W. Roesky}

for his constant guidance, motivation, suggestions, and discussions throughout this work.

I thank Professor J. Magull, D. Vidovic, H.-G. Schmidt, Dr. M. Noltemeyer, V. Jancik, Dr. R. Herbst-Irmer for their help in the X-ray crystal structure investigations and their friendliness. I thank W. Zolke, J. Schöne, Dr. G. Elter (NMR investigations), Dr. D. Böhler, T. Schuchardt, A. Rehsein (Mass spectral measurements), M. Hesse, H.-J. Feine (IR spectral measurements), J. Schimkowiak, M. Schlote, and the staff of the Analytical Laboratories for their timely support during this research work.

I thank all my colleagues in our research group for the good and motivating work atmosphere. I would like to express my special thanks to Dr. Y. Ding, Dr. C. Cui, Dr. H. Hao and Dr. G. Bai for their help in the initial stages of my work, and H. Zhu, Dr. J. Rong, Dr. A. Ganapathi, S. Shravan Kumar, J. Chai, Dr. J. Li, T. Blunck, Dr. C. He, Z. Yang, Dr. S. Bhandari, Dr. D. Neculai, Dr. A. M. Neculai, Dr. N. D. Reddy, L. W. Pineda, S. Singh, H.-J. Ahn, Dr. A. Stasch, Dr. M. Schiefer, Dr. M. Gorol, Dr. J. Prust, Dr. H. Hohmeister, Dr. J. Janssen, and U. Nehete for their friendly support. The help rendered by Dr. M. Witt during the writing of this thesis is gratefully acknowledged.

I am grateful to my former supervisor Prof. S. Lu at the Fujian Institute of Research on the Structure of Matter at Chinese Academy of Sciences from whom I learnt my early lessons of research.

I thank my husband Dr. H. Fan for his aid of theoretical calculations, support and encouragement which helped me to accomplish this work. I also thank my parents, brother and sister, and relatives for their moral support during this work. 


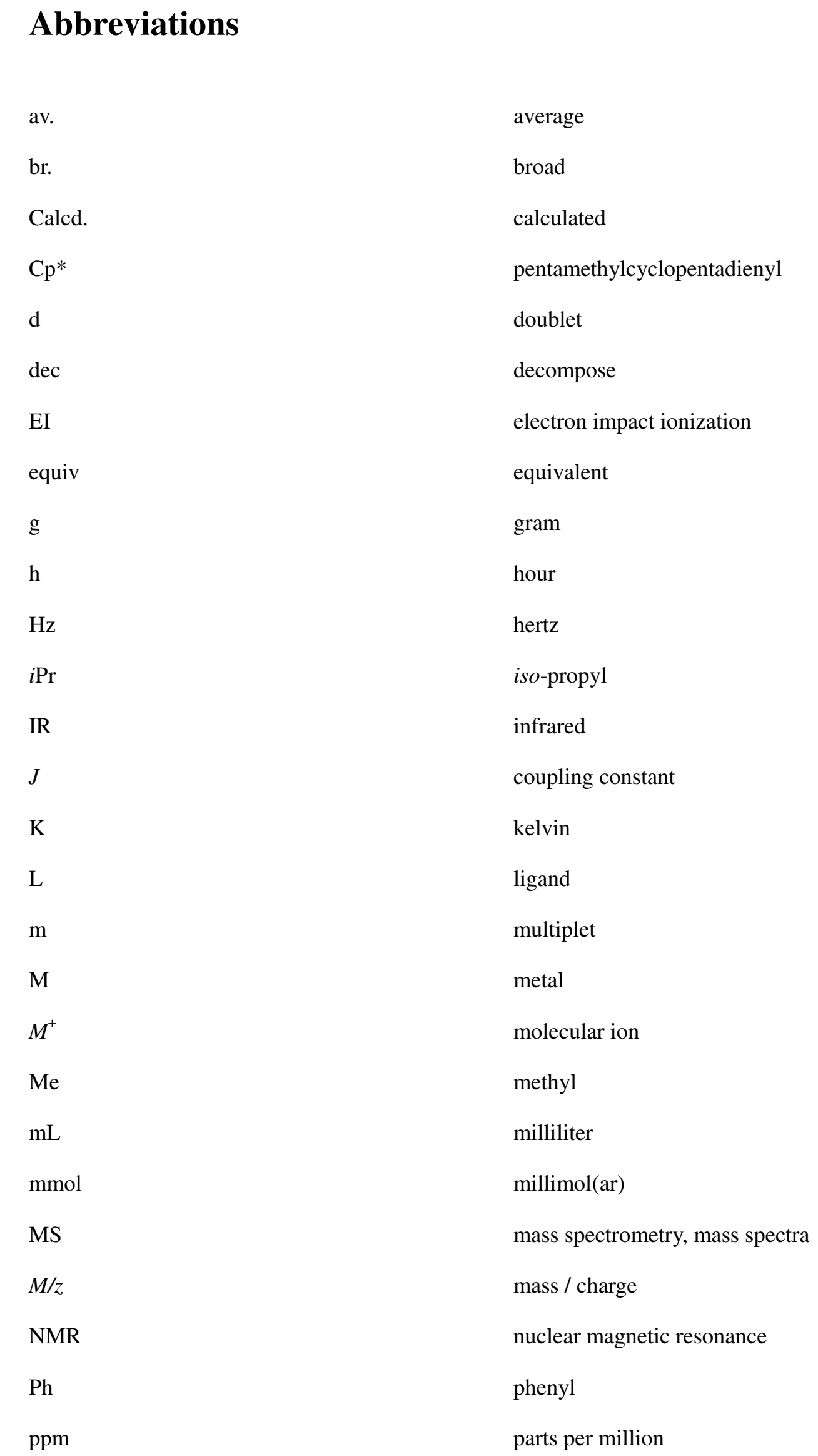


$\mathrm{R}$

S

sept.

$\mathrm{t}$

Tert.

THF

Z

$\delta$

$\lambda$

$\mu$

V organic substituent

singlet

septet

triplet

tertiary

tetrahydrofuran

number of molecules in the unit cell

chemical shift

wavelength

bridging

wave number 


\section{Table of Contents}

\section{Introduction}

1.1. Organometallic compounds with salicylaldiminato ligand ……....................... 2

1.2. Hydrolysis of organoaluminum compounds ……......................................... 3

1.3. Heteroatom-containing organoaluminum cage compounds …......................... 5

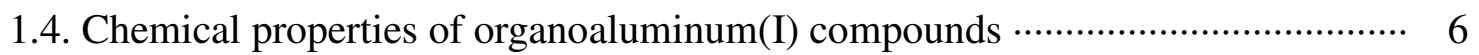

1.5. Scope and aims of this dissertation ……….............................................. 9

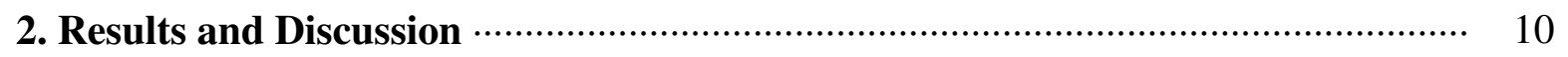

2.1. Aluminum monohydride and chalcogenides bearing a bidentate [N,O] ligand $\cdots \quad 10$

2.1.1. Preparation of bidentate salicylaldimine [3- $t \mathrm{Bu}-5-\mathrm{Me}-2-\mathrm{OH}-\mathrm{C}_{6} \mathrm{H}_{2}-$

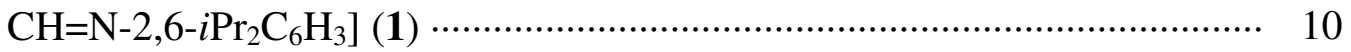

2.1.2. Preparation of aluminum monohydride (3- $t \mathrm{Bu}-5-\mathrm{Me}-2-\mathrm{O}-\mathrm{C}_{6} \mathrm{H}_{2} \mathrm{CH}_{2}$

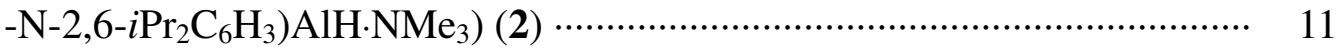

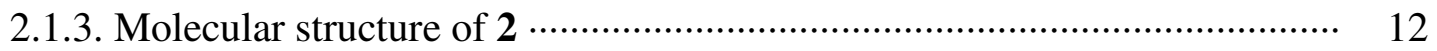

2.1.4. Preparation of chalcogenide derivatives [(3- $t \mathrm{Bu}-5-\mathrm{Me}-2-\mathrm{O}-\mathrm{C}_{6} \mathrm{H}_{2}$

$\left.\left.\mathrm{CH}_{2}-\mathrm{NH}-2,6-i \mathrm{Pr}_{2} \mathrm{C}_{6} \mathrm{H}_{3}\right) \mathrm{Al}(\mu-\mathrm{E})\right]_{2}[\mathrm{E}=\mathrm{S}(\mathbf{3}), \mathrm{Se}(\mathbf{4})] \cdots \cdots \cdots \cdots \cdots \cdots \cdots \cdots \cdots \cdots \cdots \cdots \cdots \cdots \cdots \cdots \cdots \cdots \cdots \cdots \cdots \cdots$

2.1.5. X-ray crystallographic analyses of compounds 3 and 4 …....................... 15

2.2. Hydrolysis of aluminum hydrides ………............................................... 19

2.2.1. Reactions of 5 and tert-butylisocyanate …......................................... 19

2.2.2. Preparation of alumoxane hydroxide $\mathrm{LAl}(\mathrm{OH}) \mathrm{OAlL}(\mathrm{OCH}=\mathrm{N}-t \mathrm{Bu})(\mathbf{8}) \cdots \cdot 20$

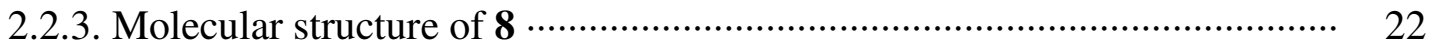

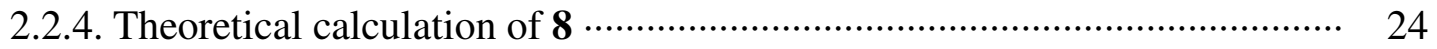

2.3. Synthesis and reactions of Al-N and Al-C-N clusters ……............................ 26

2.3.1. Preparation and reactions of unusual heptameric aluminum imides 9 and

10

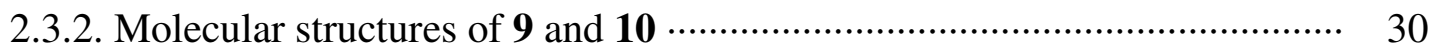

2.3.3. Preparation and X-ray structural analysis of 11 ...................................... 37

2.4. Reactions of monomeric organoaluminum(I) compounds ….......................... 40 
2.4.1. Preparation and structural analysis of $\left[\mathrm{HC}(\mathrm{CPhNAr})_{2}\right] \mathrm{AlMe}_{2}(\mathrm{Ar}=$ 2,6-i $\left.i \mathrm{Pr}_{2} \mathrm{C}_{6} \mathrm{H}_{3}\right)(\mathbf{1 3})$

2.4.2. Preparation of $\left[\mathrm{HC}(\mathrm{CMeNAr})_{2}\right]_{2} \mathrm{Al}_{2} \mathrm{P}_{4}\left(\mathrm{Ar}=2,6-\mathrm{Pr}_{2} \mathrm{C}_{6} \mathrm{H}_{3}\right)(\mathbf{1 4})$ with a

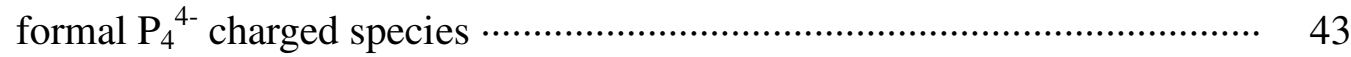

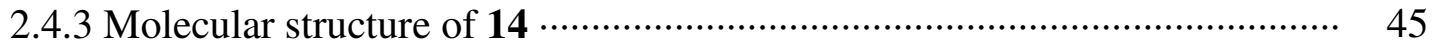

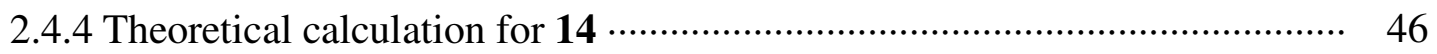

2.4.5. Preparation of a bimetallic derivative of the sulfur crown $S_{8}$ :

$\mathrm{LAl}\left(\mu-\mathrm{S}_{3}\right)_{2} \mathrm{AlL}\left(\mathrm{L}=\mathrm{HC}(\mathrm{CMeNAr})_{2}, \mathrm{Ar}=2,6-i \mathrm{Pr}_{2} \mathrm{C}_{6} \mathrm{H}_{3}\right)(\mathbf{1 5}) \ldots \ldots \ldots \ldots \ldots \ldots \ldots . .48$

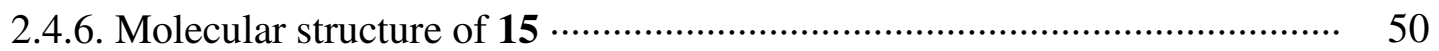

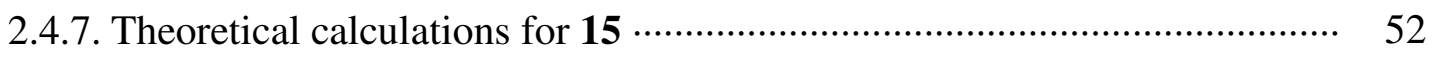

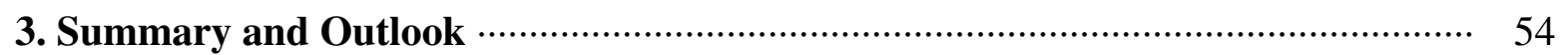

3.1 Summary

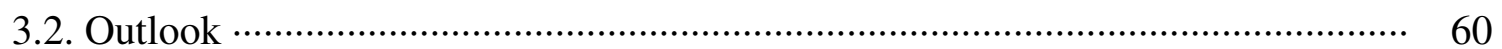

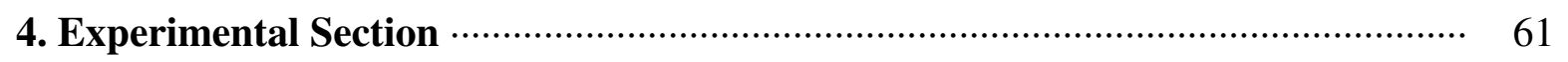

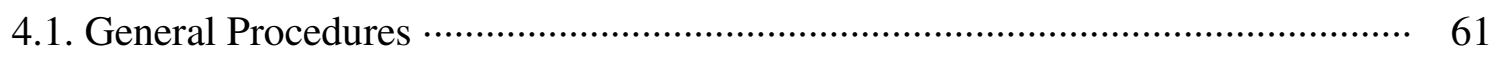

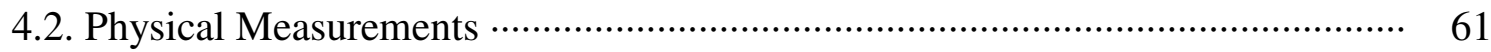

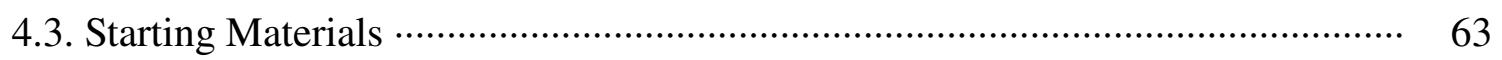

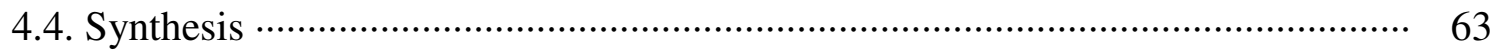

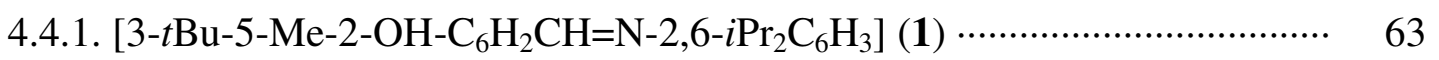

4.4.2. [3- $\left.t \mathrm{Bu}-5-\mathrm{Me}-2-\mathrm{O}-\mathrm{C}_{6} \mathrm{H}_{2} \mathrm{CH}_{2}-\mathrm{N}-2,6-i \mathrm{Pr}_{2} \mathrm{C}_{6} \mathrm{H}_{3}\right] \mathrm{AlH}\left(\mathrm{NMe}_{3}\right)(2) \ldots \ldots \ldots \ldots \ldots \ldots . . . . .64$

4.4.3. [(3- $\left.\left.t \mathrm{Bu}-5-\mathrm{Me}-2-\mathrm{O}-\mathrm{C}_{6} \mathrm{H}_{2} \mathrm{CH}_{2}-\mathrm{NH}-2,6-i \mathrm{Pr}_{2} \mathrm{C}_{6} \mathrm{H}_{3}\right) \mathrm{Al}(\mu-\mathrm{S})\right]_{2}(3) \cdots \cdots \cdots \cdots \cdots \cdots \cdots \cdots$

4.4.4. [(3- $\left.\left.t \mathrm{Bu}-5-\mathrm{Me}-2-\mathrm{O}-\mathrm{C}_{6} \mathrm{H}_{2} \mathrm{CH}_{2}-\mathrm{NH}-2,6-i \mathrm{Pr}_{2} \mathrm{C}_{6} \mathrm{H}_{3}\right) \mathrm{Al}(\mu-\mathrm{Se})\right]_{2}(4) \ldots \ldots \ldots \ldots \ldots \ldots . . . . . .65$

4.4.5. $\mathrm{LAlH}(\mathrm{OCH}=\mathrm{N}-t \mathrm{Bu})\left(\mathrm{L}=\mathrm{HC}(\mathrm{CMeNAr})_{2}, \mathrm{Ar}=2,6-i \mathrm{Pr}_{2} \mathrm{C}_{6} \mathrm{H}_{3}\right)(\mathbf{6}) \ldots \ldots \ldots \ldots . .65$

4.4.6. $\mathrm{LAl}(\mathrm{OCH}=\mathrm{N}-t \mathrm{Bu})_{2}\left(\mathrm{~L}=\mathrm{HC}(\mathrm{CMeNAr})_{2}, \mathrm{Ar}=2,6-i \mathrm{Pr}_{2} \mathrm{C}_{6} \mathrm{H}_{3}\right)(7) \ldots \ldots \ldots \ldots \ldots . .66$

4.4.7. $\mathrm{LAl}(\mathrm{OH}) \mathrm{OAlL}(\mathrm{OCH}=\mathrm{N}-t \mathrm{Bu})\left(\mathrm{L}=\mathrm{HC}(\mathrm{CMeNAr})_{2}, \mathrm{Ar}=2,6-\right.$

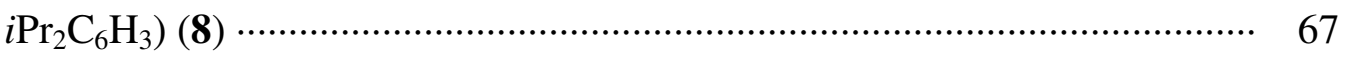

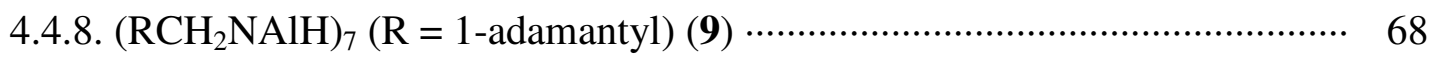

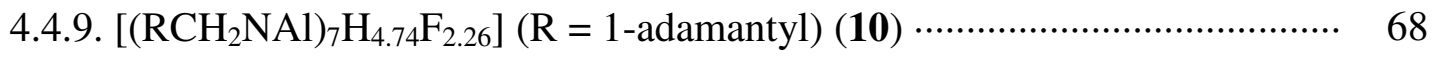

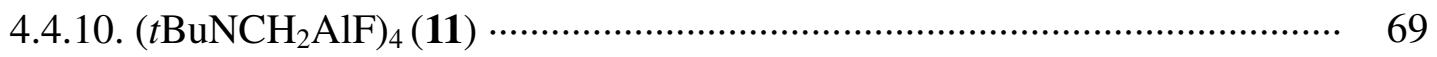




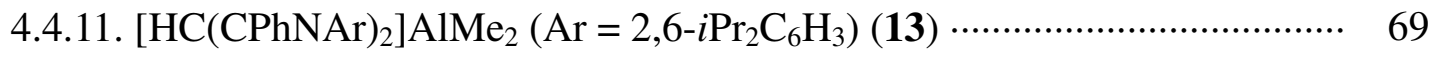

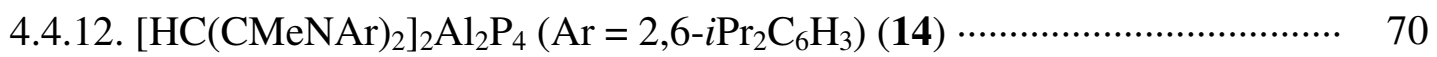

4.4.13. $\mathrm{LAl}\left(\mu-\mathrm{S}_{3}\right)_{2} \mathrm{AlL}\left(\mathrm{L}=\mathrm{HC}(\mathrm{CMeNAr})_{2}, \mathrm{Ar}=2,6-i \mathrm{Pr}_{2} \mathrm{C}_{6} \mathrm{H}_{3}\right)(\mathbf{1 5}) \cdots \cdots \cdots \cdots \cdots \cdots . . . . \cdots$

5. Handling and Disposal of Solvents and Residual Waste ……............................... 72

6. Crystal Data and Refinement Details ……........................................................... 74

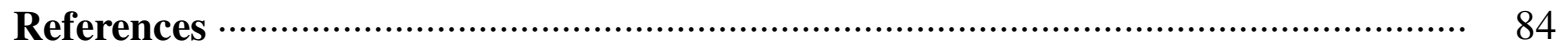




\section{Introduction}

Aluminum derives its name from alum, a double sulphate, $\mathrm{KAl}\left(\mathrm{SO}_{4}\right)_{2} \cdot 12 \mathrm{H}_{2} \mathrm{O}$ which has been used medicinally as an astrigent since Classical Greek and Roman times. Aluminum is a grayish white metal and the most abundant metal in the lithosphere. As an extremely reactive metal aluminum rapidly obtains a stable surface oxide layer on exposure to air and moisture, thus it is found mostly in its oxidized and complexed forms. The high abundance of aluminum has resulted in a multitude of applications for the element and its compounds. It is the major constituent of many common minerals, including feldspars and micas. Moreover, aluminum plays an important role as a part of alloys.

In 1859, W. Hallwachs and A. Schafarik reported the first organoaluminum compound $\mathrm{Et}_{3} \mathrm{Al}_{2} \mathrm{I}_{3}$ from the reaction of elemental $\mathrm{Al}$ and EtI. ${ }^{1 \mathrm{a}}$ Although known as a highly reactive species for more than a century it was only since 1950 that organoaluminum compounds have gained interest. This development was triggered by the pioneering work of K. Ziegler et al. for the discovery of low pressure polymerisation of olefins with organoaluminum/transition metal catalysts. ${ }^{1 \mathrm{~b}, 1 \mathrm{c}}$ Since then organoaluminum complexes generated considerable attention due to their increasing role in polymerisation chemistry, e.g. in cationic, ${ }^{2 a, 2 b}$ anionic $^{2 c-2 e}$ and ring-opening polymerisation, ${ }^{2 \mathrm{f}}$ and as cocatalyts/activators in transition metal-catalysed olefin polymerisation. ${ }^{2 \mathrm{~g}}$ In addition, neutral aluminum alkyls have long been known to promote the oligomerisation of ethylene to yield $\alpha$-olefins at elevated temperature and pressure. ${ }^{2 \mathrm{~h}}$ More recently, cationic aluminum alkyls have shown to polymerise ethylene under mild conditions. 


\subsection{Organometallic compounds with salicylaldiminato ligand}

In recent years there has been considerable and growing interest in the coordination chemistry of bulky bi- and tridentate ligands, in part because these ligands can be used to provide protective shielding for catalytically active metal centers. This protection strategy is the one which we employed in aluminum chemistry to get some unusual compounds. The salicylaldiminato ligand framework has a long history as an ancillary ligand system in coordination and organometallic chemistry. It is readily accessible and shows good solubility in common organic solvents. Moreover, salicylaldiminato ligands have played an important role in a range of olefin polymerisation catalyst systems. ${ }^{3}$ The alkyl or aryl groups on the aldimine nitrogen and the phenoxide ring show the diversity of such ligands with flexible coordination abilities. The common coordination mode is bidentate, and tridentate with pendant arm on the aldimine nitrogen atom.
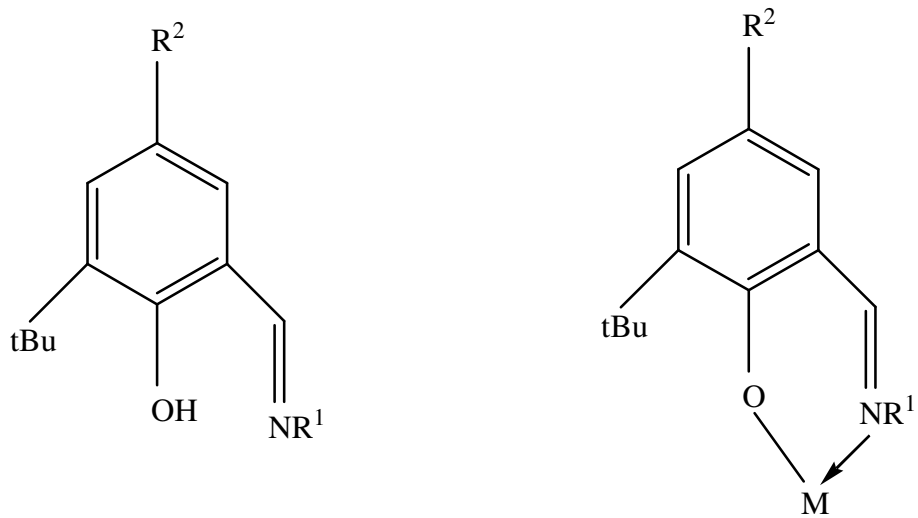

$\mathrm{R}^{1}=2,6-\mathrm{Me}_{2} \mathrm{C}_{6} \mathrm{H}_{3}, 2,6-i \mathrm{Pr}_{2} \mathrm{C}_{6} \mathrm{H}_{3}, 3,5-\left(\mathrm{CF}_{3}\right)_{2} \mathrm{C}_{6} \mathrm{H}_{3}, 4-\left(\mathrm{NO}_{2}\right) \mathrm{C}_{6} \mathrm{H}_{4}, 4-\mathrm{ClC}_{6} \mathrm{H}_{4}$, 1-naphthyl, $t \mathrm{Bu}$,

$\mathrm{C}_{6} \mathrm{H}_{5}, \mathrm{C}_{6} \mathrm{~F}_{5} ; \quad \mathrm{R}^{2}=t \mathrm{Bu}, \mathrm{H} ; \quad \mathrm{M}=$ metal 

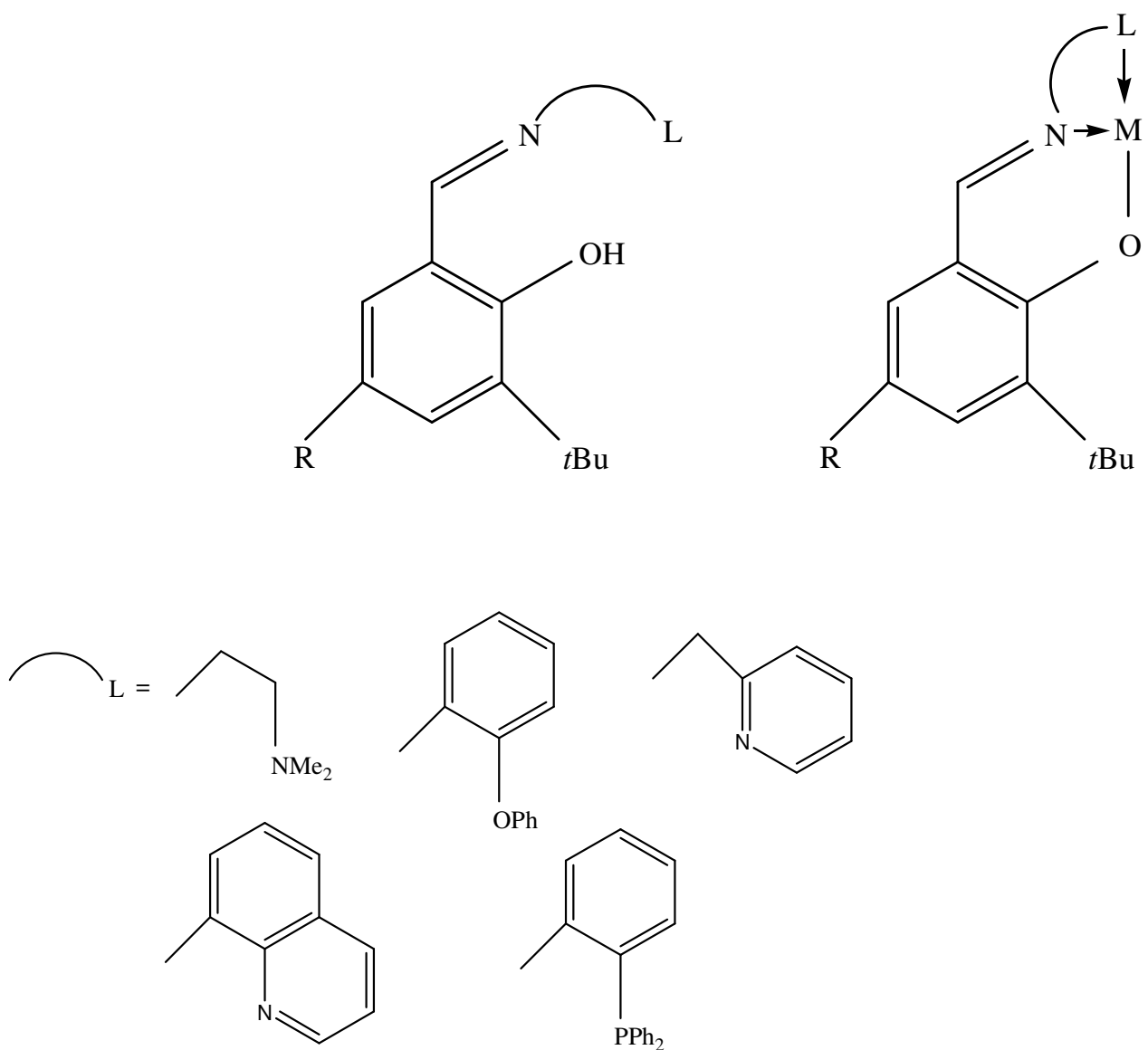<smiles>Cc1ccccc1Oc1ccccc1</smiles><smiles>CCc1ccccn1</smiles>

$\mathrm{R}=t \mathrm{Bu}, \mathrm{H}$

It is extensively employed in both early and late transition metals. ${ }^{3 a, 3 c, 4}$ This type of ligand was introduced to aluminum chemistry mainly to prepare alkyl aluminum complexes ${ }^{5}$ and their cationic derivatives by reactions with $\mathrm{AlR}_{2} \mathrm{X}(\mathrm{R}=$ alkyl group, $\mathrm{X}=$ alkyl group or $\mathrm{Cl})$, which can be used as ethylene polymerisation catalysts. ${ }^{5 \mathrm{~d}}$ To the best of our knowledge, there have been no reports of aluminum hydride species stabilised by Schiff base [N,O] chelate ligands.

\subsection{Hydrolysis of organoaluminum compounds}

In 1980 the investigation by Sinn and Kaminsky et al. that methylaluminoxane (MAO) is 
a highly active cocatalyst in ethylene and propylene polymerisation by group 4 metallocenes, ${ }^{6}$ has promoted the studies on the structural determination of aluminoxane to exemplify its role in the polymerisation reactions. Although the role of MAO seems clear, ${ }^{6 c-6 e}$ the molecular structure of the active aluminoxane species is an open question. Aluminoxanes, containing the $\mathrm{Al}-\mathrm{O}-\mathrm{Al}$ unit, are generally prepared by the controlled hydrolysis of aluminum alkyls or aryls with water or reactive oxygen-containing species such as $\mathrm{CO}_{2}, \mathrm{RCONR}_{2}, \mathrm{MeCO}_{2} \mathrm{H}$ and $\mathrm{Me}_{2} \mathrm{SO} .^{7-9,11}$ To obtain the related aluminoxanes, controlled amounts of water have to be introduced into a solution of $\mathrm{R}_{3} \mathrm{Al}$ at low temperatures. Aluminoxanes easily associate to yield di-, tri-, tetra-, and oligoaluminoxanes. ${ }^{9 b, 9 c, 40 a}$ These properties of aluminoxanes make the preparation of a particular aluminoxane in a crystalline form and the determination of their crystal structures difficult. However, reactions with organoaluminum hydrides have been only investigated in a few cases. ${ }^{10}$ Recent studies demonstrated two effective methods for the hydrolysis of aluminum compounds. ${ }^{12-13}$ In a liquid ammonia/toluene two-phase system the first terminal aluminum dihydroxide $\mathrm{LAl}(\mathrm{OH})_{2}\left(\mathrm{~L}=\mathrm{HC}(\mathrm{CMeNAr})_{2}, \mathrm{Ar}=2,6-i \mathrm{Pr}_{2} \mathrm{C}_{6} \mathrm{H}_{3}\right)^{12 \mathrm{a}}$ was obtained by the reaction of $\mathrm{LAlI}_{2}$ with $\mathrm{KOH}$ containing water and $\mathrm{KH}$. In the same system a dinuclear aluminoxane ${ }^{12 b}$ containing a terminal hydroxide and six-membered aluminoxane was obtained.

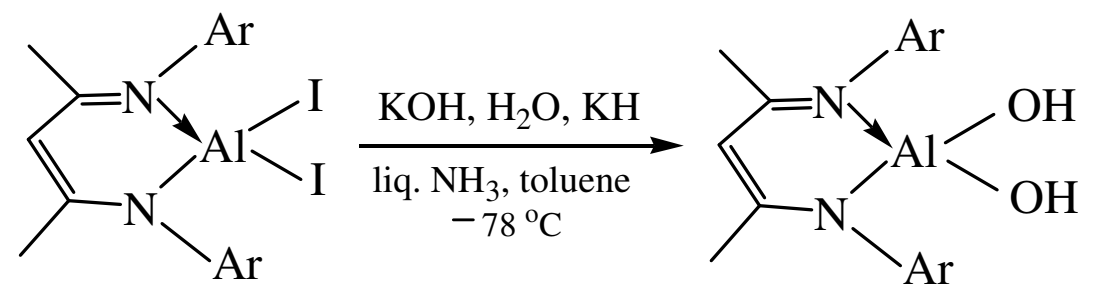



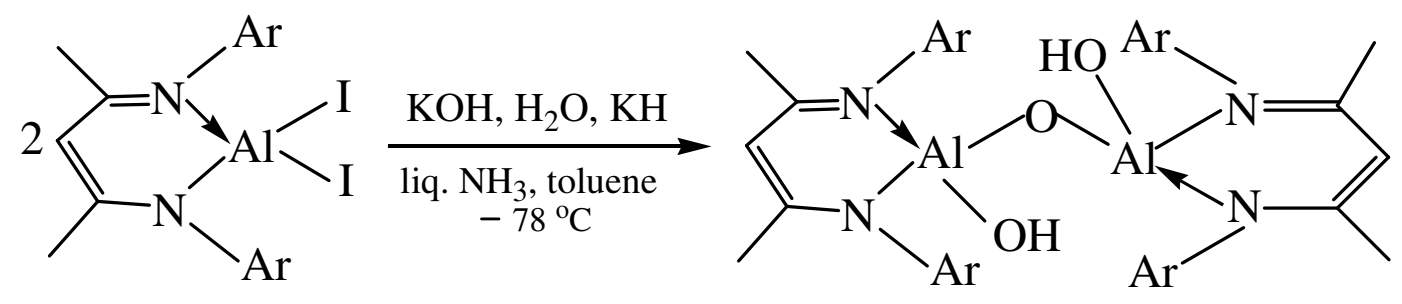

$\mathrm{Ar}=2,6-i \mathrm{Pr}_{2} \mathrm{C}_{6} \mathrm{H}_{3}$

Another method is the reaction of water with organoaluminum dichlorides and an N-heterocyclic carbene is used as $\mathrm{HCl}$ acceptor. ${ }^{13}$ This method is also effective in the hydrolysis of germanium chloride. ${ }^{14}$

$\mathrm{LAlCl}_{2} \frac{2 \mathrm{Ct}, 2 \mathrm{H}_{2} \mathrm{O}}{-2 \mathrm{Ct} \cdot \mathrm{HCl}} \mathrm{LAl}(\mathrm{OH})_{2}$

$\mathrm{L}=\mathrm{HC}(\mathrm{CMeNAr})_{2}, \mathrm{Ar}=2,6-i \mathrm{Pr}_{2} \mathrm{C}_{6} \mathrm{H}_{3} ; \mathrm{Ct}=1,3-t \mathrm{Bu}_{2}$ imidazole-2-ylidene

In numerous studies several low aggregated aluminoxanes containing bridging $\mathrm{OH}$ groups have been described. ${ }^{9 c, 15}$ However, the synthesis and isolation of aluminum compounds with terminal hydroxides are rarely known.

\subsection{Heteroatom-containing organoaluminum cage compounds}

Much attention was paid recently to oligomeric and polyhedral compounds of aluminum containing Al-N and Al-C cores. Heteroatom-containing organoaluminum cage compounds are potential precursor for the chemical vapor deposition of aluminum nitride. ${ }^{16}$ Moreover, their application in catalysis, ${ }^{17}$ as reducing agents, and as synthetic intermediates ${ }^{18}$ have attracted much interest. $\mathrm{AlH}_{3} \cdot \mathrm{NMe}_{3}$ is an effective precursor to prepare low aggregated organoaluminum hydrides. ${ }^{10 b, 19}$ When it is used to react with compounds containing C-N and 
$\mathrm{C}-\mathrm{C}$ multiple bonds, structural interesting $\mathrm{Al}-\mathrm{N}$ and $\mathrm{Al}-\mathrm{C}$ clusters containing reactive $\mathrm{Al}-\mathrm{H}$ bonds were obtained. ${ }^{20}$ There have been some reports on the formation of aluminum imides from reactions 1-3.

$$
\begin{aligned}
& \mathrm{AlH}_{3} \cdot \mathrm{NMe}_{3}+\mathrm{RNH}_{2} \longrightarrow 1 / \mathrm{n}(\mathrm{RNAlH})_{\mathrm{n}}+2 \mathrm{H}_{2}+\mathrm{NMe}_{3} \\
& \mathrm{LiAlH}_{4}+\mathrm{RNH}_{2} \cdot \mathrm{HCl} \longrightarrow 1 / \mathrm{n}(\mathrm{RNAlH})_{\mathrm{n}}+3 \mathrm{H}_{2}+\mathrm{LiCl} \\
& \mathrm{AlH}_{3} \cdot \mathrm{NMe}_{3}+\mathrm{RCN} \longrightarrow 1 / \mathrm{n}\left(\mathrm{RCH}_{2} \mathrm{NAlH}\right)_{\mathrm{n}}
\end{aligned}
$$

The degree of Al-N association is predominantly dependent on three factors:

(a) Steric bulk of the alkyl group $\mathrm{R}$ on the amine,

(b) The organic substituents coordinating to aluminum atoms,

(c) The reaction conditions.

A few crystal structures of aluminum imides $(n=4,6$ or 8$)$ containing hydridic hydrogen bound to aluminum atoms have been obtained. ${ }^{21,22}$ However, compounds of composition $(\mathrm{RNAlH})_{7}$ with $\mathrm{Al}-\mathrm{H}$ bonds are not known. The reaction of heteroalkyne with an excess of $\mathrm{AlH}_{3} \cdot \mathrm{NMe}_{3}$ results in the formation of a carbaaminoalane with an $\mathrm{Al}_{4} \mathrm{C}_{4} \mathrm{~N}_{4}$ skeleton. ${ }^{20 \mathrm{a}}$ The hydrides on the aluminum atoms of these aluminum imides and carbaaminoalane are highly reactive and readily replaceable by nucleophilic reagents while the core of the cluster seems to be rather stable.

\subsection{Chemical properties of organoaluminum(I) compounds}

Aluminum is known to have a rich chemistry in its trivalent state. ${ }^{23}$ Compared with the fascinating variety of the borane structures or the vast field of the subhalides of indium and 
thallium, the chemistry of subvalent aluminum compounds are less studied especially for the organoaluminum(I) compounds. Aluminum(I) species have been often postulated as intermediates in photochemical and free radical reactions of organoaluminum(III) reagents. ${ }^{1 \mathrm{c}}$ In 1991 Schnöckel et al. reported the first stable organoaluminum(I) compound $(\mathrm{Cp} * \mathrm{Al})_{4}{ }^{24}$ which readily dissociates into the more reactive monomer $\left(\mathrm{Cp}^{*} \mathrm{Al}\right)^{25}$ in the gas phase or in solution at higher temperatures. There are some reviews ${ }^{26,27}$ about the reactivity of the tetramer $\left(\mathrm{Cp}^{*} \mathrm{Al}\right)_{4}$. For example, $(\mathrm{Cp} * \mathrm{Al})_{4}$ can be oxidised with the elements $\mathrm{P}^{28} \mathrm{Se}$ and $\mathrm{Te}^{29}$ to afford interesting products.

$6 \mathrm{Cp}^{*} \mathrm{Al}+\mathrm{P}_{4} \underset{25^{\circ} \mathrm{C}}{\stackrel{\text { toluene }}{\longrightarrow}}\left(\mathrm{Cp}^{*} \mathrm{Al}\right)_{6} \mathrm{P}_{4}$
$4 \mathrm{Cp}^{*} \mathrm{Al}+4 \mathrm{E} \underset{2{ }^{\circ} \mathrm{C}}{\stackrel{\text { toluene }}{\longrightarrow}}\left(\mathrm{Cp}^{*} \mathrm{Al}\right)_{4} \mathrm{E}_{4}$

$\mathrm{E}=\mathrm{Se}, \mathrm{Te}$

When $(\mathrm{Cp} * \mathrm{Al})_{4}$ is reacted with $\mathrm{Me}_{3} \mathrm{SiN}_{3}$, a dimeric iminoalane is obtained. ${ }^{30}$

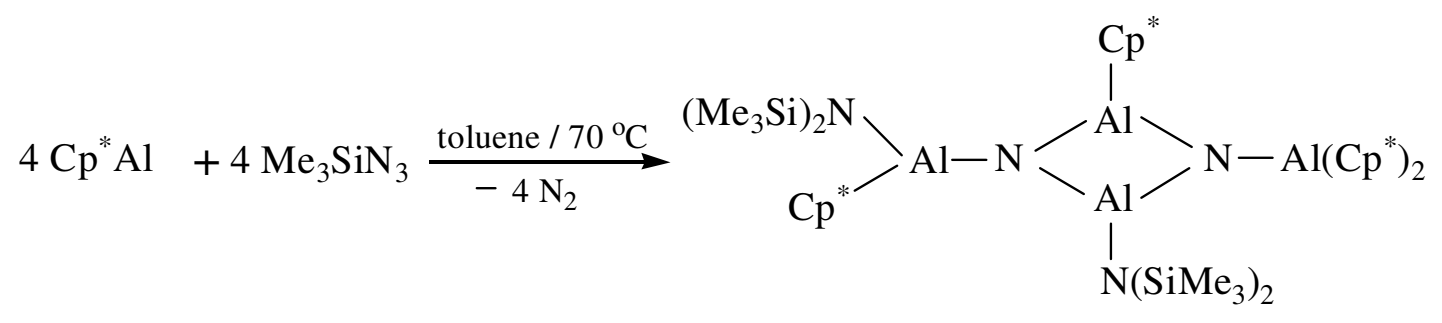

By exploring the bulky $\beta$-diketiminato ligand $\mathrm{L}$, the first stable monomeric $\mathrm{Al}^{\mathrm{I}}$ compound $\mathrm{LAl}^{\mathrm{I}}\left(\mathrm{L}=\mathrm{HC}(\mathrm{CMeNAr})_{2}, \mathrm{Ar}=2,6-i \mathrm{Pr}_{2} \mathrm{C}_{6} \mathrm{H}_{3}\right)$ was reported. ${ }^{31}$ Compared to $(\mathrm{Cp} * \mathrm{Al})_{4}, \mathrm{LAl}^{\mathrm{I}}$ is more active and shows a completely different chemical behaviour. When treated with $\mathrm{Me}_{3} \mathrm{SiN}_{3}$, a cyclic aluminum-containing tetrazole was formed. ${ }^{32}$ 


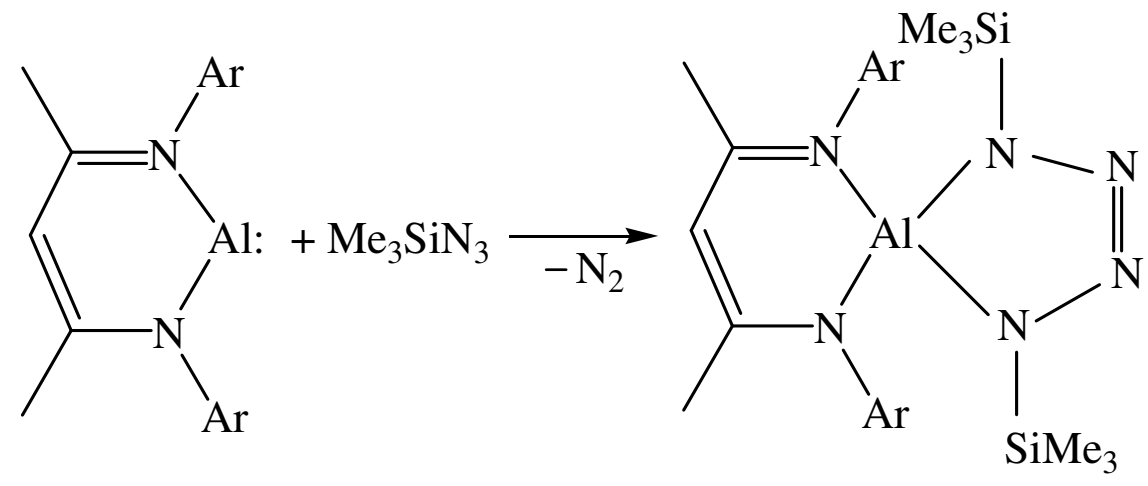

$\mathrm{Ar}=2,6-i \mathrm{Pr}_{2} \mathrm{C}_{6} \mathrm{H}_{3}$

More examples of reactions with $\mathrm{LAl}^{\mathrm{I}}$ are listed below: ${ }^{33}$

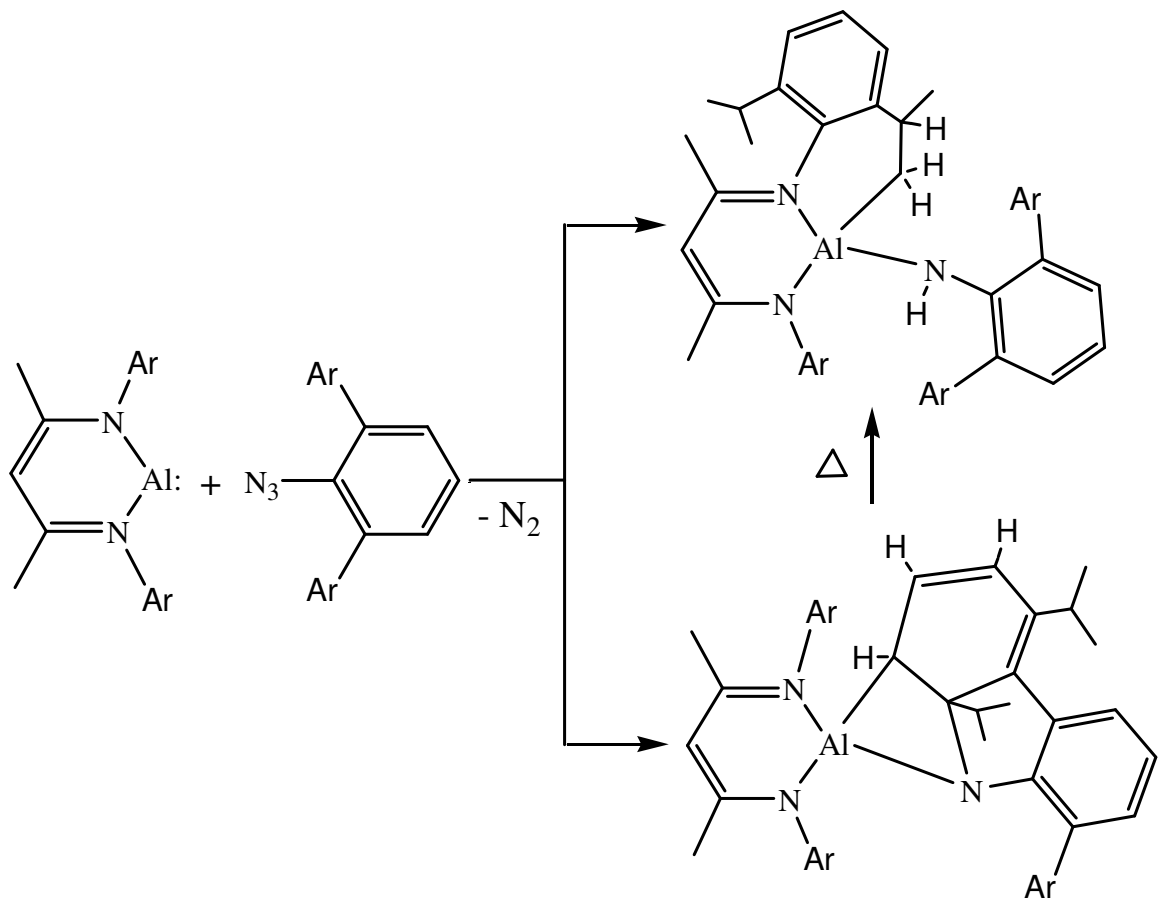

$\mathrm{Ar}=2,6-i \mathrm{Pr}_{2} \mathrm{C}_{6} \mathrm{H}_{3}$

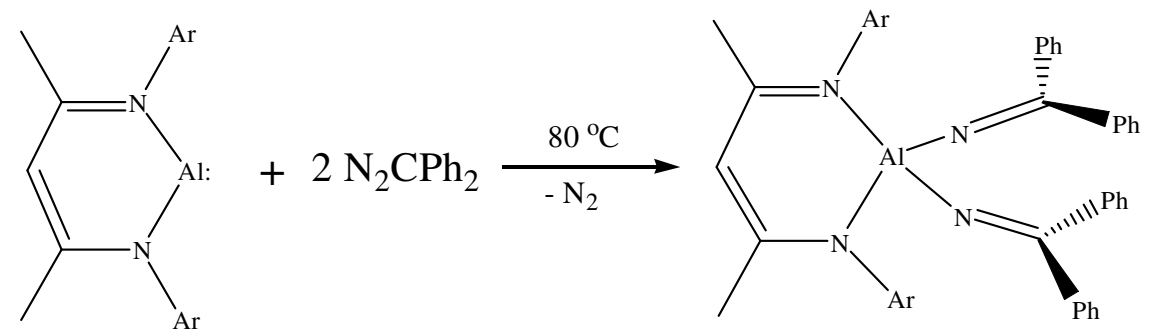

$\mathrm{Ar}=2,6-i \mathrm{Pr}_{2} \mathrm{C}_{6} \mathrm{H}_{3}$ 


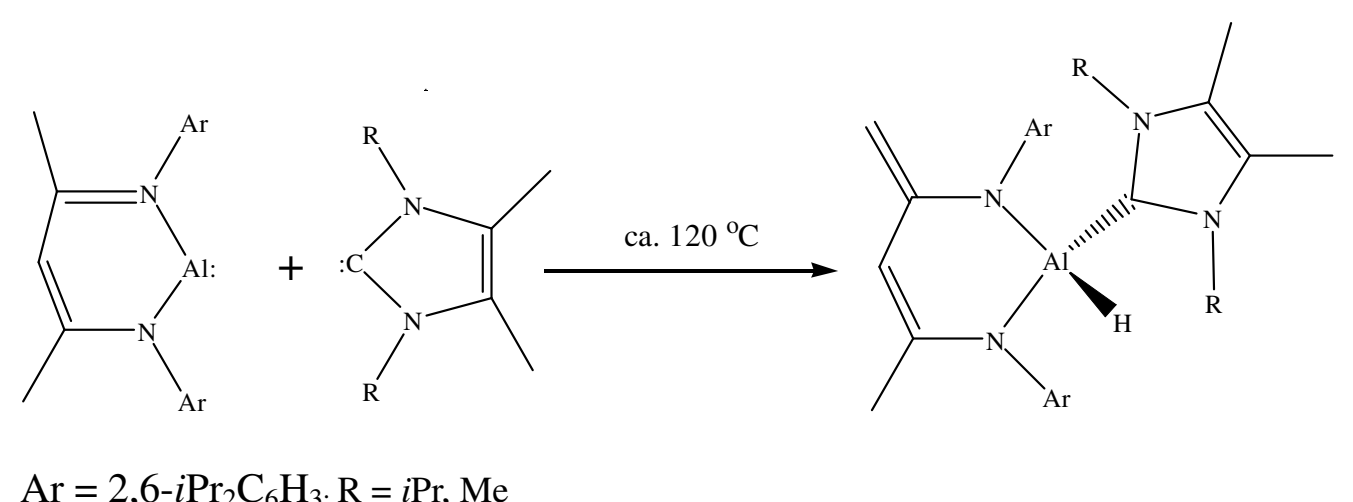

$\mathrm{Ar}=2,6-i \mathrm{Pr}_{2} \mathrm{C}_{6} \mathrm{H}_{3} ; \mathrm{R}=i \mathrm{Pr}, \mathrm{Me}$

In this thesis some more reactions will be reported to enrich the $\mathrm{LAl}^{\mathrm{I}}$ chemistry.

\subsection{Scope and aims of this dissertation}

As discussed above, organoaluminum compounds have been widely investigated as cocatalysts, reagents as well as precursor for inorganic materials such as ceramics, semidonductors, zeolites. The bulky ligand is very important to synthesise lowaggregated and low-valent aluminum species.

The objectives of the present work are:

(1) Studies of aluminum compounds stabilised by the bidentate salicylaldiminato ligand.

(2) Preparation of terminal hydroxide containing dinuclear aluminoxane.

(3) Synthesis of heptameric aluminum imide and surface fluorination products of the $\mathrm{Al}_{7} \mathrm{~N}_{7}$ and $\mathrm{Al}_{4} \mathrm{C}_{4} \mathrm{~N}_{4}$ cores.

(4) Examination of the reactivities of monomeric organoaluminum(I) compounds. 


\section{Results and Discussion}

\subsection{Aluminum monohydride and chalcogenides bearing a bidentate $[\mathrm{N}, \mathrm{O}]$ ligand}

Salicylaldiminato ligands are extensively used in transition metal complexes, ${ }^{3 a, 3 c, 4}$ and there are some reports on the aluminum chemistry by exploring this kind of ligands. ${ }^{5}$ No example is known for an aluminum hydride bearing this type of ligand. Heavier group 13 element chalcogenides have been widely studied due to their important applications in chemical vapour deposition (CVD) and catalysis, ${ }^{34}$ and organoaluminum hydrides of low aggregation have proved to be effective reagents for preparing chalcogenide compounds with elemental chalcogens or organochalcogenides, ${ }^{35}$ such as $\mathrm{LAl}(\mathrm{SeH})_{2}, \mathrm{LAl}(\mathrm{SeH}) \mathrm{Se}(\mathrm{SeH}) \mathrm{AlL}(\mathrm{L}$ $\left.=\mathrm{HC}(\mathrm{CMeNAr})_{2}, \quad \mathrm{Ar}=2,6-i \operatorname{Pr}_{2} \mathrm{C}_{6} \mathrm{H}_{3}\right),{ }^{19 \mathrm{a}} \mathrm{LAl}(\mathrm{SH})_{2} \quad\left(\mathrm{~L}=\mathrm{HC}(\mathrm{CMeNAr})_{2}, \quad \mathrm{Ar}=\right.$ 2,6-i $\left.\operatorname{Pr}_{2} \mathrm{C}_{6} \mathrm{H}_{3}\right),{ }^{36} \mathrm{Al}_{4} \mathrm{Se}_{5}(\mathrm{H})_{2}\left(\mathrm{NMe}_{3}\right)_{4} \cdot{ }^{35 \mathrm{~d}}$ As an extension of this type of reaction, we explored a bidentate salicylaldimine [3- $t \mathrm{Bu}-5-\mathrm{Me}-2-\mathrm{OH}-\mathrm{C}_{6} \mathrm{H}_{2} \mathrm{CH}=\mathrm{N}-2,6-i \mathrm{Pr}_{2} \mathrm{C}_{6} \mathrm{H}_{3}$ ] $(\mathbf{1})^{37}$ to react with $\mathrm{AlH}_{3} \cdot \mathrm{NMe}_{3}$ to afford an aluminum monohydride (3- $t \mathrm{Bu}-5-\mathrm{Me}-2-\mathrm{O}-$ $\left.\mathrm{C}_{6} \mathrm{H}_{2} \mathrm{CH}_{2}-\mathrm{N}-2,6-i \mathrm{Pr}_{2} \mathrm{C}_{6} \mathrm{H}_{3}\right) \mathrm{AlH} \cdot \mathrm{NMe}_{3}$ (2) under elimination of hydrogen together with hydrogen migration from the metal to the ligand backbone. We also described its chalcogenide derivatives $\left[\left(3-t \mathrm{Bu}-5-\mathrm{Me}-2-(\mathrm{O}) \mathrm{C}_{6} \mathrm{H}_{2} \mathrm{CH}_{2}-\mathrm{NH}-2,6-i \mathrm{Pr}_{2} \mathrm{C}_{6} \mathrm{H}_{3}\right) \mathrm{Al}(\mu-\mathrm{E})\right]_{2} \quad[\mathrm{E}=\mathrm{S}$ (3), Se (4)] from the reaction of 2 with sulphur and selenium, and the possible reaction mechanism was discussed as well.

\subsubsection{Preparation of bidentate salicylaldimine $\left[3-t \mathrm{Bu}-5-\mathrm{Me}-2-\mathrm{OH}-\mathrm{C}_{6} \mathrm{H}_{2} \mathrm{CH}=\mathrm{N}\right.$ -} 2,6-i $\left.\mathrm{Pr}_{2} \mathrm{C}_{6} \mathrm{H}_{3}\right](\mathbf{1})$ 
The bidentate salicylaldimine $\mathbf{1}$ was obtained as a yellow crystalline solid in good yield (90\%) by condensation of 4-methyl-6-tertbutylsalicylaldehyde with 2,6-diisopropylaniline in refluxing ethanol in the presence of catalytic amounts of formic acid. Spectroscopic data are consistent with the composition of $\mathbf{1}$ shown in Scheme 1 and satisfactory elemental analysis were obtained. The EI mass spectrum of $\mathbf{1}$ exhibits an intense peak for the molecular ion. The IR absorptions at $3400 \mathrm{~cm}^{-1}$ and $1620 \mathrm{~cm}^{-1}$ show the existence of $\mathrm{O}-\mathrm{H}$ and $\mathrm{CH}=\mathrm{N}$ stretches respectively, and resonances at $\delta 8.03(\mathrm{CH}=\mathrm{N})$ and $13.89(-\mathrm{OH})$ in the ${ }^{1} \mathrm{H}$ NMR spectrum also support the presence of these groups in $\mathbf{1}^{5 \mathrm{a}}$

\subsubsection{Preparation of aluminum monohydride (3- $t \mathrm{Bu}-5-\mathrm{Me}-2-\mathrm{O}-\mathrm{C}_{6} \mathrm{H}_{2} \mathrm{CH}_{2}-\mathrm{N}-2,6$} $\left.-i \mathrm{Pr}_{2} \mathrm{C}_{6} \mathrm{H}_{3}\right) \mathrm{AlH} \cdot \mathrm{NMe}_{3}(2)$

Reaction of 1 with a small excess of $\mathrm{AlH}_{3} \cdot \mathrm{NMe}_{3}{ }^{38}$ in toluene at $0{ }^{\circ} \mathrm{C}$ or alternatively under refluxing conditions in toluene afforded the aluminum monohydride (3- $\left.t \mathrm{Bu}-5-\mathrm{Me}-2-\mathrm{O}-\mathrm{C}_{6} \mathrm{H}_{2} \mathrm{CH}_{2}-\mathrm{N}-2,6-i \mathrm{Pr}_{2} \mathrm{C}_{6} \mathrm{H}_{3}\right) \mathrm{Al} \cdot \mathrm{H}\left(\mathrm{NMe}_{3}\right)$ (2) in good yield under elimination of hydrogen. (Scheme 1). Furthermore, hydrogen migration from the aluminum atom to the

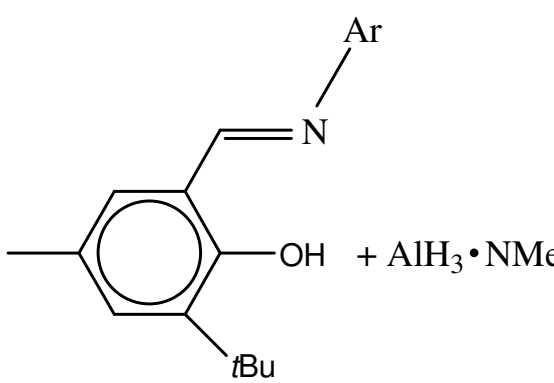

1

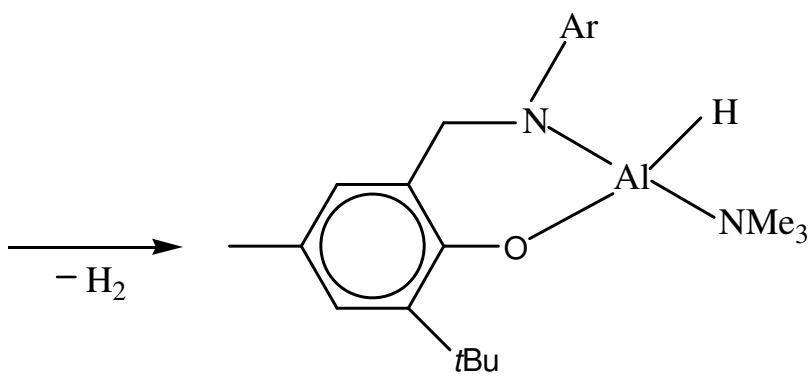

2

$\mathrm{Ar}=2,6-i \mathrm{Pr}_{2} \mathrm{C}_{6} \mathrm{H}_{3}$

\section{Scheme 1}


ligand backbone occurred at the $\mathrm{CH}=\mathrm{N}$ double bond to give the $\mathrm{CH}_{2} \mathrm{~N}$ species. A migration reaction of a methyl group was not observed when $\mathrm{AlMe}_{3}$ was used instead, and the $\mathrm{CH}=\mathrm{N}$ double bond was retained in the bidentate salicylaldiminato ligand. ${ }^{5 \mathrm{a}-5 \mathrm{c}} \mathrm{We}$ assume that this is due to the higher reactivity of $\mathrm{AlH}_{3} \cdot \mathrm{NMe}_{3}$ compared to that of $\mathrm{AlMe}_{3}$. However, a methyl group migration was noted in the reaction of the tridentate salicylaldimine $\left[3,5-t \mathrm{Bu}_{2}-2-\mathrm{OH}-\mathrm{C}_{6} \mathrm{H}_{2} \mathrm{CH}=\mathrm{NR}\right]\left(\mathrm{R}=8-\mathrm{C}_{9} \mathrm{H}_{6} \mathrm{~N}\right.$ (quinoline) with $\mathrm{AlMe}_{3}$ at $110{ }^{\circ} \mathrm{C} .{ }^{5 \mathrm{e}}$ Moreover, we believe that both the 2,6-i $\mathrm{Pr}_{2} \mathrm{C}_{6} \mathrm{H}_{3}$ group on the aldimine nitrogen and the bulky ortho $t \mathrm{Bu}$ group on the phenoxide ring of $\mathbf{1}$ prevent the dimerization of $\mathbf{2}$. Compound $\mathbf{2}$ is well soluble in common organic solvents, such as toluene, benzene- $\mathrm{d}_{6}$, hexane and pentane. The broad IR band at $1837 \mathrm{~cm}^{-1}$ can be assigned to the Al-H stretching frequency. ${ }^{39}$ Absorptions for the $\mathrm{CH}=\mathrm{N}$ double bond and the $\mathrm{O}-\mathrm{H}$ group are absent in the IR of 2.

\subsubsection{Molecular structure of 2}

Compound 2 crystallises in the monoclinic space group $P 2_{1} / c$ with one molecule of toluene in the unit cell. The structure of $\mathbf{2}$ shows a distorted tetrahedral aluminum centre (Figure 1). Selected bond lengths and angles for $\mathbf{2}$ are listed in Table 1. The terminal Al-H bond length $(1.479(2) \AA)$ is similar to that of $\left[\mathrm{ArN}\left(\mathrm{CH}_{2}\right)_{3} \mathrm{NAr}\right] \mathrm{AlHNMe} 3\left(\mathrm{Ar}=2,6-i \mathrm{Pr}_{2} \mathrm{C}_{6} \mathrm{H}_{3}\right)$ $(1.52 \AA)^{35 a}$. The Al-N(1) bond distance $(1.799(1) \AA)$ is much shorter than those of $\left(3,5-t \mathrm{Bu}_{2}-2-\mathrm{O}-\mathrm{C}_{6} \mathrm{H}_{2} \mathrm{CH}=\mathrm{NR}\right) \mathrm{AlMe}_{2}\left(\mathrm{R}=2,6-\mathrm{Me}_{2} \mathrm{C}_{6} \mathrm{H}_{3}\right.$ or $\left.2,6-i \mathrm{Pr}_{2} \mathrm{C}_{6} \mathrm{H}_{3}\right)(1.972(3), 1.972(3) \AA)$ bearing the unchanged bidentate salicylaldiminato ligands. ${ }^{5 a}$ The $\mathrm{Al}-\mathrm{N}(2)$ bond length (2.000(1) $\AA$ ) in 2 is comparable to those of $\left[\mathrm{ArN}\left(\mathrm{CH}_{2}\right)_{3} \mathrm{NAr}\right] \mathrm{AlRNMe}\left(\mathrm{Ar}=2,6-i \mathrm{Pr}_{2} \mathrm{C}_{6} \mathrm{H}_{3}, \mathrm{R}\right.$ $=\mathrm{H}, \mathrm{F})(2.024(2), 2.000(2) \AA) .{ }^{35 \mathrm{a}}$ The reason for the shorter Al-N(1) is due to the covalent 
bond character, while all the other Al-N bonds mentioned above are coordinating bonds. The Al-O distance $(1.741(1) \AA)$ is a little shorter than those of $\left(3,5-t \mathrm{Bu}_{2}-2-\mathrm{O}-\mathrm{C}_{6} \mathrm{H}_{2} \mathrm{CH}=\mathrm{NR}\right) \mathrm{AlMe}$ $\left(\mathrm{R}=2,6-\mathrm{Me}_{2} \mathrm{C}_{6} \mathrm{H}_{3}\right.$ or $\left.2,6-i \mathrm{Pr}_{2} \mathrm{C}_{6} \mathrm{H}_{3}\right)(1.755(3), 1.773(3) \AA)^{5} .{ }^{5 a}$ Compared to the corresponding retained $\mathrm{CH}=\mathrm{N}$ double bond in $\left(3,5-t \mathrm{Bu}_{2}-2-\mathrm{O}-\mathrm{C}_{6} \mathrm{H}_{2} \mathrm{CH}=\mathrm{NR}\right) \mathrm{AlMe}_{2}\left(\mathrm{R}=2,6-\mathrm{Me}_{2} \mathrm{C}_{6} \mathrm{H}_{3}\right.$ or 2,6-i $\left.\mathrm{Pr}_{2} \mathrm{C}_{6} \mathrm{H}_{3}\right)\left(1.285(5), 1.300(5) \AA{ }^{5},{ }^{5 \mathrm{a}}\right.$ the $\mathrm{N}(1)-\mathrm{C}(24)$ bond length $(1.478(2) \AA)$ in 2 shows a typical $\mathrm{C}-\mathrm{N}$ single bond character. In 1 the two phenyl rings are coplanar because they are conjugated through the $\mathrm{CH}=\mathrm{N}$ double bond. However in 2, as the result of the hydrogen migration the conjugation is broken and the two planes become nearly vertical for steric reasons. $\mathrm{O}(1)-\mathrm{Al}(1)-\mathrm{N}(1)-\mathrm{C}(24)$ is nearly coplanar and the same is observed for $\mathrm{C}(24)-\mathrm{C}(14)-\mathrm{C}(13)-\mathrm{O}(1)$. The angle between the two planes is about $40^{\circ}$ and may be due to the steric effects.

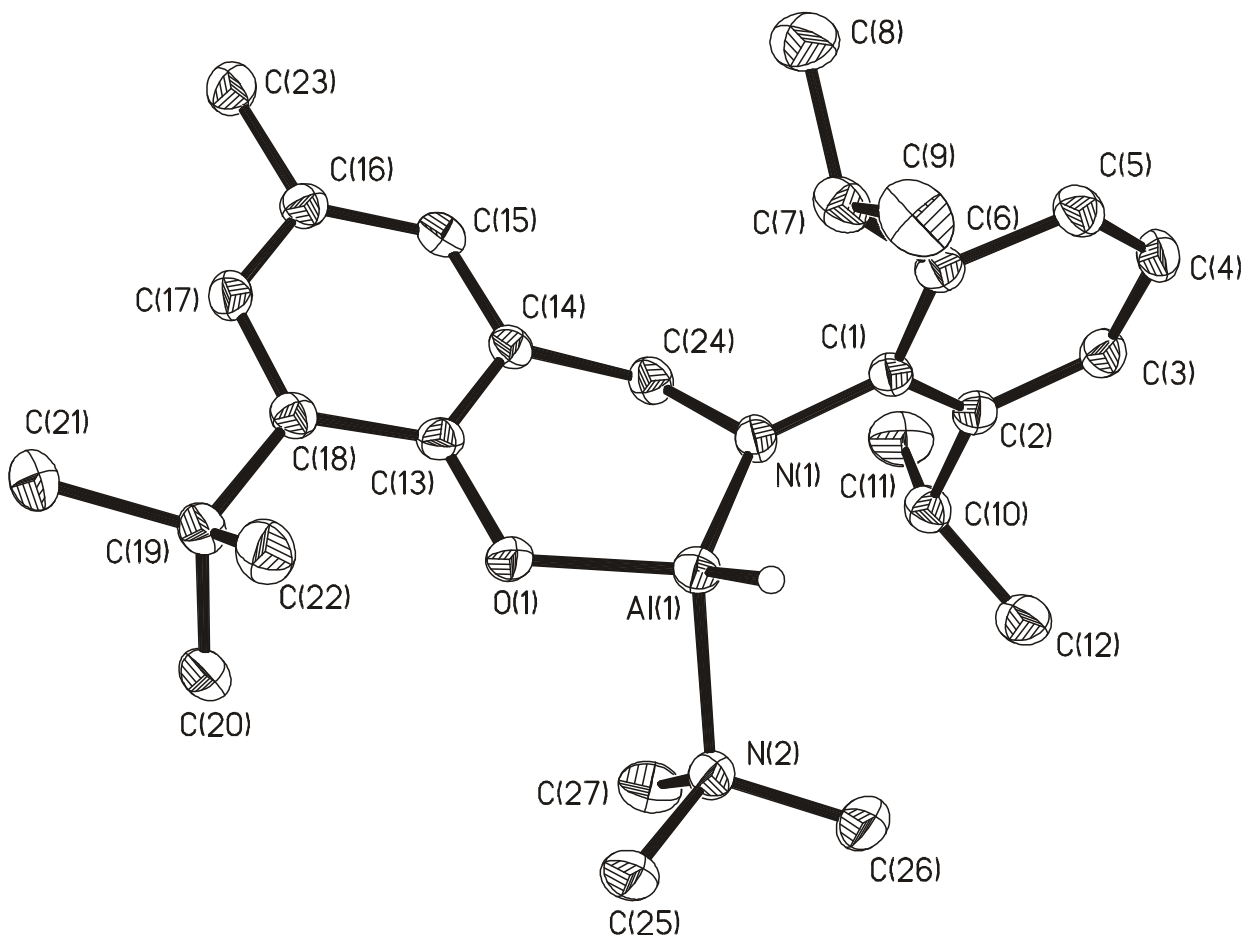

Figure 1. The molecular structure of $\mathbf{2}$. The solvent molecule and the hydrogen atoms are omitted for clarity except for the Al-H hydrogen atom. 
Table 1. Selected bond lengths $(\AA)$ and angles $\left(^{\circ}\right)$ for 2 .

\begin{tabular}{llll}
\hline $\mathrm{Al}(1)-\mathrm{O}(1)$ & $1.741(1)$ & $\mathrm{N}(1)-\mathrm{Al}(1)-\mathrm{N}(2)$ & $117.07(6)$ \\
$\mathrm{Al}(1)-\mathrm{N}(1)$ & $1.799(1)$ & $\mathrm{H}(1)-\mathrm{Al}(1)-\mathrm{O}(1)$ & $121.2(6)$ \\
$\mathrm{Al}(1)-\mathrm{N}(2)$ & $2.000(1)$ & $\mathrm{H}(1)-\mathrm{Al}(1)-\mathrm{N}(1)$ & $118.9(6)$ \\
$\mathrm{Al}(1)-\mathrm{H}(1)$ & $1.479(2)$ & $\mathrm{H}(1)-\mathrm{Al}(1)-\mathrm{N}(2)$ & $100.3(6)$ \\
$\mathrm{N}(1)-\mathrm{C}(24)$ & $1.478(2)$ & $\mathrm{C}(24)-\mathrm{N}(1)-\mathrm{Al}(1)$ & $117.19(9)$ \\
$\mathrm{C}(14)-\mathrm{C}(24)$ & $1.521(2)$ & $\mathrm{N}(1)-\mathrm{C}(24)-\mathrm{C}(14)$ & $115.63(1)$ \\
$\mathrm{C}(14)-\mathrm{C}(13)$ & $1.405(2)$ & $\mathrm{C}(13)-\mathrm{C}(14)-\mathrm{C}(24)$ & $121.56(13)$ \\
$\mathrm{O}(1)-\mathrm{C}(13)$ & $1.3649(18)$ & $\mathrm{O}(1)-\mathrm{C}(13)-\mathrm{C}(14)$ & $119.58(13)$ \\
$\mathrm{O}(1)-\mathrm{Al}(1)-\mathrm{N}(1)$ & $102.32(6)$ & $\mathrm{C}(13)-\mathrm{O}(1)-\mathrm{Al}(1)$ & $124.49(9)$ \\
$\mathrm{O}(1)-\mathrm{Al}(1)-\mathrm{N}(2)$ & $95.45(5)$ & & \\
\hline
\end{tabular}

2.1.4. Preparation of the chalcogenide derivatives $\left[\left(3-t \mathrm{Bu}-5-\mathrm{Me}-2-\mathrm{O}-\mathrm{C}_{6} \mathrm{H}_{2} \mathrm{CH}_{2}-\mathrm{NH}-2,6\right.\right.$ $\left.\left.-i \operatorname{Pr}_{2} \mathrm{C}_{6} \mathrm{H}_{3}\right) \mathrm{Al}(\mu-\mathrm{E})\right]_{2}[\mathrm{E}=\mathrm{S}(3), \mathrm{Se}(4)]$

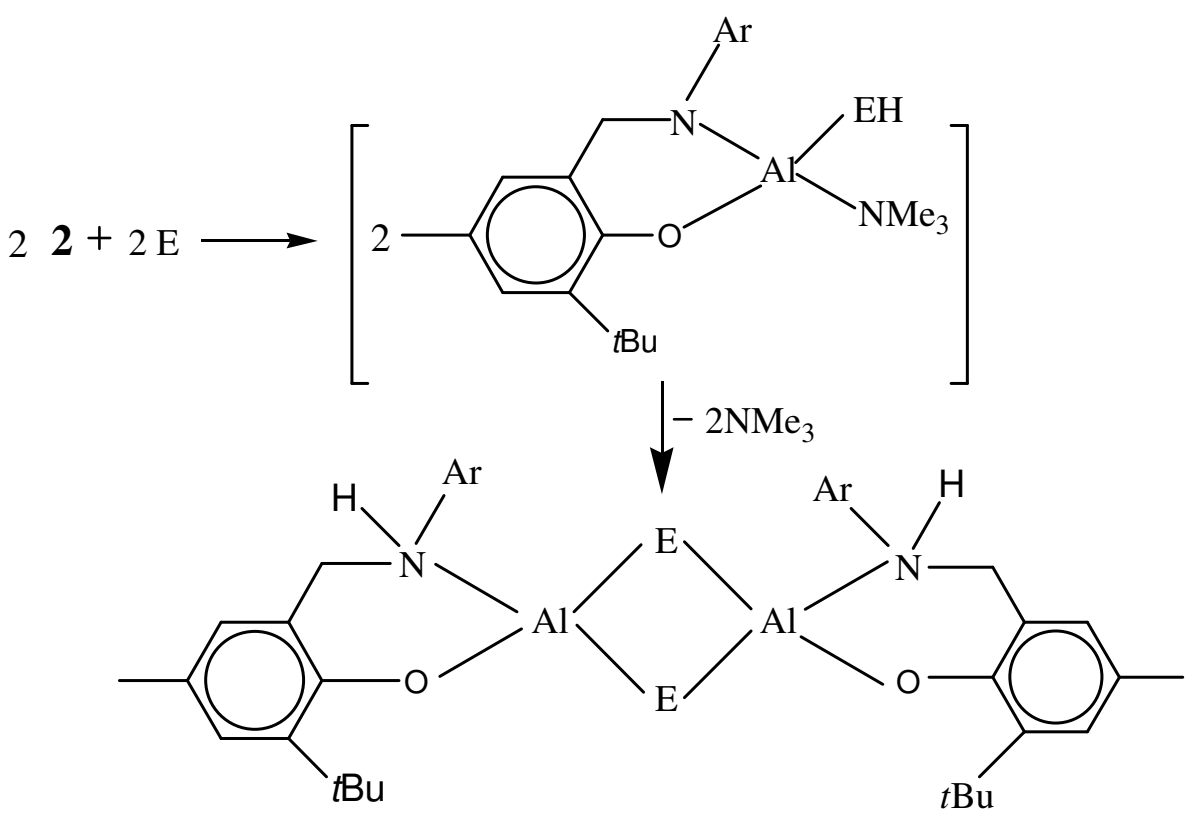

3, 4

$\mathrm{E}=\mathrm{S}(\mathbf{3}), \mathrm{Se}(\mathbf{4}) ; \mathrm{Ar}=2,6-i \mathrm{Pr}_{2} \mathrm{C}_{6} \mathrm{H}_{3}$

Scheme 2 
Treatment of 2 with elemental sulphur and selenium in toluene yielded the dimeric aluminum chalcogenides $\left[\left(3-t \mathrm{Bu}-5-\mathrm{Me}-2-\mathrm{O}-\mathrm{C}_{6} \mathrm{H}_{2} \mathrm{CH}_{2}-\mathrm{NH}-2,6-i \mathrm{Pr}_{2} \mathrm{C}_{6} \mathrm{H}_{3}\right) \mathrm{Al}(\mu-\mathrm{E})\right]_{2}[\mathrm{E}=\mathrm{S}(3)$, Se (4)] bearing the hydrogenated bidentate salicylaldiminato ligand (Scheme 2). Compounds 3 and $\mathbf{4}$ are air and moisture sensitive, soluble in toluene, and only sparingly soluble in benzene. They were characterised by IR, NMR and EI mass spectrometry as well as elemental analysis. No bands for the $\mathrm{CH}=\mathrm{N}$ stretches were found in the IR spectra. We assume that the formation of $\mathbf{3}$ and $\mathbf{4}$ might proceed through the reactive intermediate [(3- $\left.\left.t \mathrm{Bu}-5-\mathrm{Me}-2-\mathrm{O}-\mathrm{C}_{6} \mathrm{H}_{2} \mathrm{CH}_{2}-\mathrm{N}-2,6-i \mathrm{Pr}_{2} \mathrm{C}_{6} \mathrm{H}_{3}\right) \mathrm{Al}(\mathrm{EH})\left(\mathrm{NMe}_{3}\right)\right](\mathrm{E}=\mathrm{S}, \mathrm{Se})$ (Scheme 2). The conversion of $\mathrm{Al}-\mathrm{H}$ to $\mathrm{Al}-\mathrm{EH}$ was observed in compounds stabilized by the bulky $\beta$-diketiminato ligand. $^{19 a, 36}$ The intermediate then dimerises to [(3- $\left.\left.t \mathrm{Bu}-5-\mathrm{Me}-2-\mathrm{O}-\mathrm{C}_{6} \mathrm{H}_{2} \mathrm{CH}_{2}-\mathrm{N}-2,6-i \mathrm{Pr}_{2} \mathrm{C}_{6} \mathrm{H}_{3}\right) \mathrm{Al}(\mu-\mathrm{EH})\right]_{2}$ with elimination of $\mathrm{NMe}_{3}$. Under heating the unstable $\left[\left(3-t \mathrm{Bu}-5-\mathrm{Me}-2-\mathrm{O}-\mathrm{C}_{6} \mathrm{H}_{2} \mathrm{CH}_{2}-\mathrm{N}-2,6-i \mathrm{Pr}_{2} \mathrm{C}_{6} \mathrm{H}_{3}\right) \mathrm{Al}(\mu-\mathrm{EH})\right]_{2}$ is converted to the stable products $\mathbf{3}$ and $\mathbf{4}$ with hydrogen migration from $\mu$-EH to nitrogen. The absorption bands at 3175 and $3220 \mathrm{~cm}^{-1}$ assigned to the $\mathrm{NH}$ stretching frequencies in the IR spectrum of 3 and 4 respectively support the proposed hydrogen migration. The protons of the NH groups are also localised in the molecular structures by X-ray analysis and ${ }^{1} \mathrm{H}$ NMR spectroscopy $(\delta$ $1.52 \mathrm{ppm} 3 ; \delta 1.88 \mathrm{ppm} \mathrm{4)}$. A comparable migration phenomenon was observed in previous reactions. ${ }^{35 \mathrm{a}}$ Both compounds decompose without melting at temperatures above $110{ }^{\circ} \mathrm{C}$.

\subsubsection{X-ray crystallographic analysis of compounds 3 and 4}

The molecular structures of compounds $\mathbf{3}$ and $\mathbf{4}$ are shown in Figures 2 and 3 respectively. Selected bond distances and angles are listed in Tables 2 and 3 respectively. 
Compounds 3 and $\mathbf{4}$ crystallise in the triclinic space group $P \overline{1}$ with two molecules of toluene. The molecular structures of $\mathbf{3}$ and $\mathbf{4}$ are similar, both of them are in $D_{2 d}$ symmetry, and have a dimeric structure featuring a planar four-membered ring with a central $\mathrm{Al}_{2} \mathrm{E}_{2}$ core. The $\mathrm{Al}-\mathrm{N}$ bond lengths (2.005(1) $\AA$ for 3; 2.009(2) A for 4) are much longer than that in 2 (1.799(1) $\AA$ ), however they are comparable to those in $\left(3,5-t \mathrm{Bu}_{2}-2-\mathrm{O}-\mathrm{C}_{6} \mathrm{H}_{2} \mathrm{CH}=\mathrm{NR}\right) \mathrm{AlMe}_{2} \quad(\mathrm{R}=$ 2,6- $\mathrm{Me}_{2} \mathrm{C}_{6} \mathrm{H}_{3}$ or 2,6- $\left.i \mathrm{Pr}_{2} \mathrm{C}_{6} \mathrm{H}_{3}\right)$ (1.972(3), 1.972(3) $\AA$ ) bearing the unchanged bidentate salicylaldiminato ligand. ${ }^{5 \mathrm{a}}$ The reason is the same as discussed above: here the Al-N bond is a coordinating one. The Al-O distances (1.750(1) $\AA$ for 3 ; 1.749(2) $\AA$ for 4) are comparable to

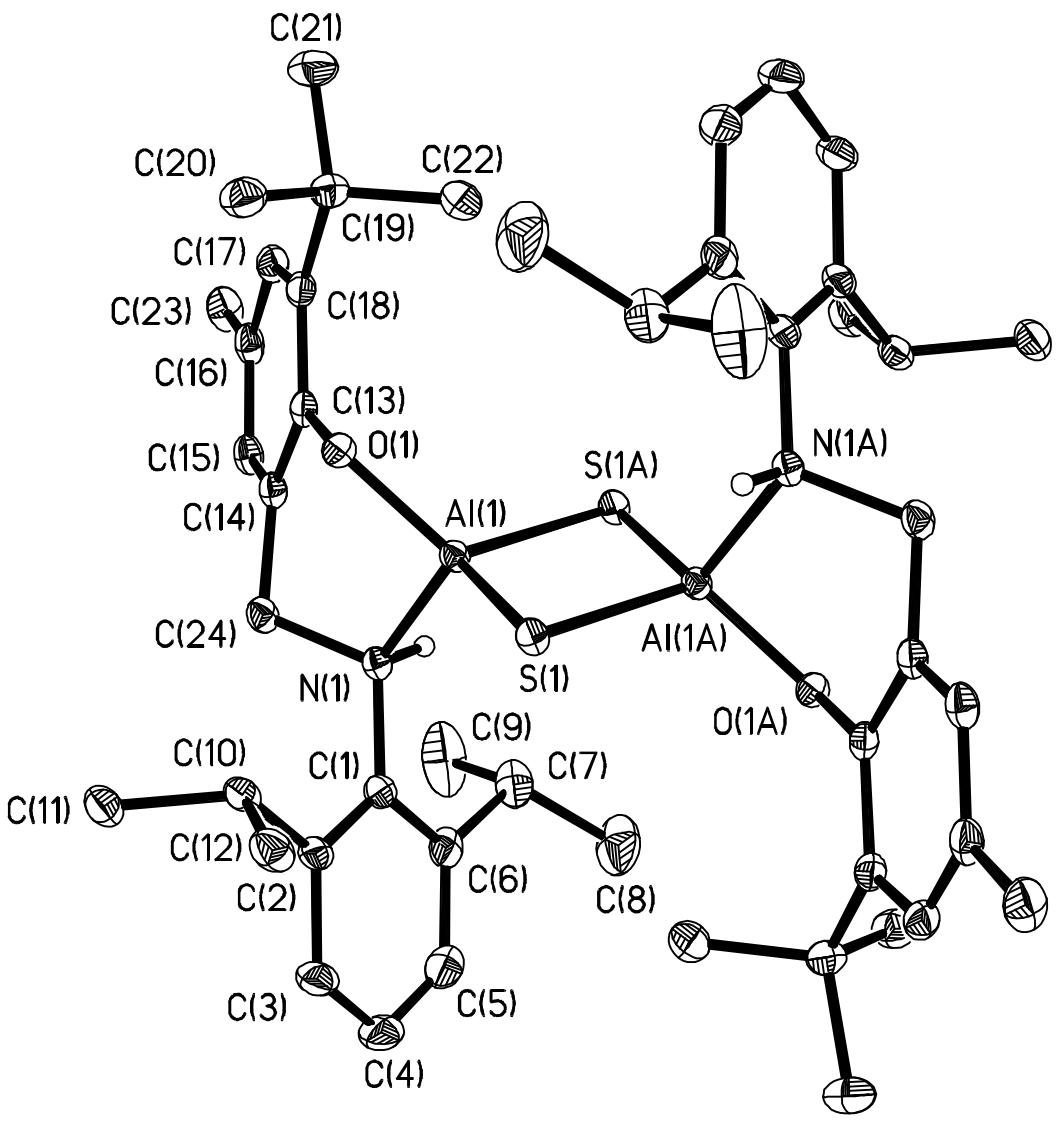

Figure 2. The molecular structure of $\mathbf{3}$. Solvent molecules and the hydrogen atoms are omitted for clarity except for the $\mathrm{N}-\mathrm{H}$ hydrogen atoms. 
that in 2 (1.741(1) $\AA$ ). The N-C bond lengths (1.510(2) $\AA$ for 3; 1.511(3) $\AA$ for 4) have single bond character like that of 2 . The Al-E distances (2.185(2), 2.232(2) $\AA$ for 3; 2.314(1), 2.366(1) $\AA$ for 4) are analogous to those of similar $\mathrm{Al}_{2} \mathrm{E}_{2}$ species. ${ }^{35}$ The $\mathrm{E}(1)-\mathrm{Al}-\mathrm{E}(1 \mathrm{~A})$ angles $\left(102.47(3)^{\mathrm{o}} \mathrm{E}=\mathrm{S} \mathrm{3} ; 104.50(3)^{\mathrm{o}} \mathrm{E}=\mathrm{Se} 4\right)$ are in the range of those reported. ${ }^{35 \mathrm{~b}}$ It is obvious that the slight difference of the Al-E distances is due to the covalent radii of the chalcogen atoms, as the covalent radii of $\mathrm{S}$ and Se differ by about $0.15 \AA(1.02 \AA$ for $\mathrm{S}$ and $1.17 \AA$ for $\mathrm{Se}){ }^{35 \mathrm{c}}$

Table 2. Selected bond lengths $(\AA)$ and angles $\left(^{\circ}\right)$ for 3 .

\begin{tabular}{llll}
\hline $\mathrm{S}(1)-\mathrm{Al}(1)$ & $2.185(2)$ & $\mathrm{O}(1)-\mathrm{Al}(1)-\mathrm{S}(1)$ & $119.92(4)$ \\
$\mathrm{S}(1)-\mathrm{Al}(1 \mathrm{~A})$ & $2.232(2)$ & $\mathrm{N}(1)-\mathrm{Al}(1)-\mathrm{S}(1)$ & $118.01(5)$ \\
$\mathrm{O}(1)-\mathrm{Al}(1)$ & $1.750(1)$ & $\mathrm{O}(1)-\mathrm{Al}(1)-\mathrm{S}(1 \mathrm{~A})$ & $117.74(4)$ \\
$\mathrm{Al}(1)-\mathrm{N}(1)$ & $2.005(1)$ & $\mathrm{N}(1)-\mathrm{Al}(1)-\mathrm{S}(1 \mathrm{~A})$ & $100.86(5)$ \\
$\mathrm{N}(1)-\mathrm{C}(24)$ & $1.510(2)$ & $\mathrm{S}(1)-\mathrm{Al}(1)-\mathrm{S}(1 \mathrm{~A})$ & $102.47(3)$ \\
$\mathrm{C}(14)-\mathrm{C}(24)$ & $1.500(2)$ & $\mathrm{C}(24)-\mathrm{N}(1)-\mathrm{Al}(1)$ & $110.60(10)$ \\
$\mathrm{C}(13)-\mathrm{C}(14)$ & $1.403(2)$ & $\mathrm{C}(1)-\mathrm{N}(1)-\mathrm{Al}(1)$ & $122.85(10)$ \\
$\mathrm{O}(1)-\mathrm{C}(13)$ & $1.3719(19)$ & $\mathrm{C}(14)-\mathrm{C}(24)-\mathrm{N}(1)$ & $111.15(1)$ \\
$\mathrm{N}(1)-\mathrm{C}(1)$ & $1.470(2)$ & $\mathrm{C}(13)-\mathrm{C}(14)-\mathrm{C}(24)$ & $118.72(14)$ \\
$\mathrm{Al}(1)-\mathrm{S}(1)-\mathrm{Al}(1 \mathrm{~A})$ & $77.53(3)$ & $\mathrm{O}(1)-\mathrm{C}(13)-\mathrm{C}(14)$ & $117.65(14)$ \\
$\mathrm{O}(1)-\mathrm{Al}(1)-\mathrm{N}(1)$ & $96.99(5)$ & $\mathrm{C}(13)-\mathrm{O}(1)-\mathrm{Al}(1)$ & $115.85(9)$ \\
\hline
\end{tabular}




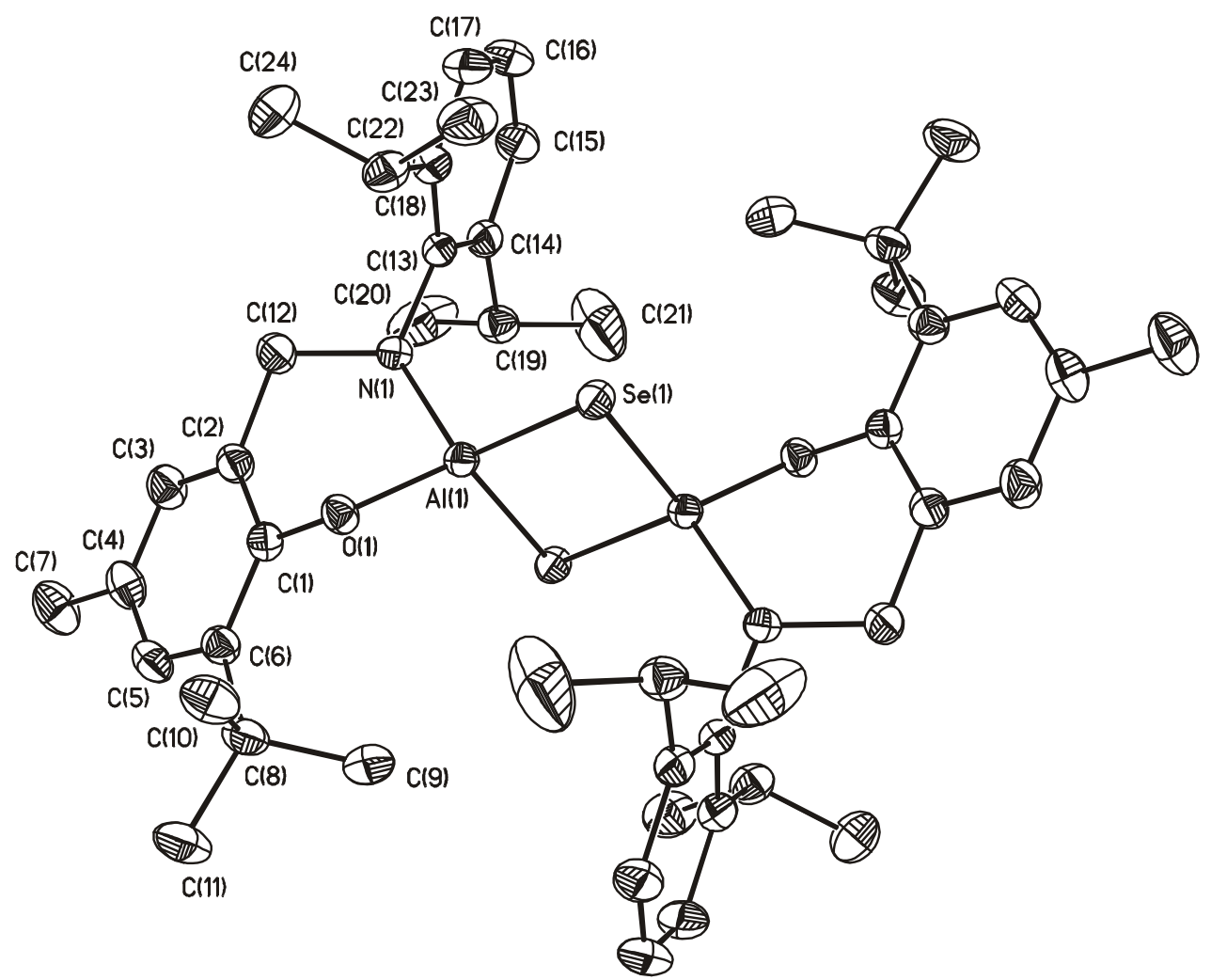

Figure 3. The molecular structure of $\mathbf{4}$. Solvent molecules and hydrogen atoms including the

$\mathrm{N}-\mathrm{H}$ hydrogen atoms are omitted for clarity.

Table 3. Selected bond lengths $(\AA)$ and angles $\left(^{\circ}\right)$ for 4 .

\begin{tabular}{llll}
\hline $\mathrm{Se}(1)-\mathrm{Al}(1)$ & $2.314(1)$ & $\mathrm{N}(1)-\mathrm{Al}(1)-\mathrm{Se}(1)$ & $118.48(7)$ \\
$\mathrm{Se}(1)-\mathrm{Al}(1 \mathrm{~A})$ & $2.366(1)$ & $\mathrm{O}(1)-\mathrm{Al}(1)-\mathrm{Se}(1 \mathrm{~A})$ & $116.08(6)$ \\
$\mathrm{Al}(1)-\mathrm{O}(1)$ & $1.749(2)$ & $\mathrm{N}(1)-\mathrm{Al}(1)-\mathrm{Se}(1 \mathrm{~A}$ & $102.25(7)$ \\
$\mathrm{Al}(1)-\mathrm{N}(1)$ & $2.009(2)$ & $\mathrm{Al}(1)-\mathrm{Se}(1)-\mathrm{Al}(1 \mathrm{~A})$ & $75.50(3)$ \\
$\mathrm{N}(1)-\mathrm{C}(12)$ & $1.511(3)$ & $\mathrm{Se}(1)-\mathrm{Al}(1)-\mathrm{Se}(1 \mathrm{~A})$ & $104.50(3)$ \\
$\mathrm{C}(2)-\mathrm{C}(12)$ & $150.2(3)$ & $\mathrm{C}(12)-\mathrm{N}(1)-\mathrm{Al}(1)$ & $111.09(15)$ \\
$\mathrm{C}(1)-\mathrm{C}(2)$ & $140.0(3)$ & $\mathrm{C}(2)-\mathrm{C}(12)-\mathrm{N}(1)$ & $110.7(2)$ \\
$\mathrm{O}(1)-\mathrm{C}(1)$ & $136.6(3)$ & $\mathrm{C}(1)-\mathrm{C}(2)-\mathrm{C}(12)$ & $118.9(2)$ \\
$\mathrm{N}(1)-\mathrm{C}(13)$ & $147.1(3)$ & $\mathrm{O}(1)-\mathrm{C}(1)-\mathrm{C}(2)$ & $117.9(2)$ \\
$\mathrm{O}(1)-\mathrm{Al}(1)-\mathrm{Se}(1)$ & $118.45(6)$ & $\mathrm{C}(1)-\mathrm{O}(1)-\mathrm{Al}(1)$ & $117.78(14)$ \\
$\mathrm{O}(1)-\mathrm{Al}(1)-\mathrm{N}(1)$ & $96.43(8)$ & $\mathrm{C}(13)-\mathrm{N}(1)-\mathrm{Al}(1)$ & $123.51(15)$ \\
\hline
\end{tabular}




\subsection{Hydrolysis of aluminum hydrides}

Despite of a number of publications concerning organoaluminoxanes, no synthesis of organoaluminoxane hydroxides from aluminum hydrides and water were reported. Herein we report the synthesis of the first aluminoxane hydroxide $\mathrm{LAl}(\mathrm{OH}) \mathrm{OAlL}(\mathrm{OCH}=\mathrm{N}-t \mathrm{Bu})(\mathbf{8})(\mathrm{L}=$ $\left.\mathrm{HC}(\mathrm{CMeNAr})_{2}, \mathrm{Ar}=2,6-i \mathrm{Pr}_{2} \mathrm{C}_{6} \mathrm{H}_{3}\right)$ by the reaction of the aluminum dihydride $\mathrm{LAlH}_{2}(\mathbf{5})^{19 \mathrm{a}}$ and tert-butylisocyanate in the presence of trace amounts of water and from $\mathbf{5}$ and $\mathrm{LAlH}(\mathrm{OCH}=\mathrm{N}-t \mathrm{Bu})(\mathbf{6})$ with water respectively.

\subsubsection{Reactions of 5 with tert-butylisocyanate}

The reaction of excess $\mathrm{LAlH}_{2}(\mathbf{5})$ with tert-butylisocyanate in refluxing toluene followed by removal of the solvent resulted in a mixture of the products 5 and $\mathbf{6}$, interaction between $\mathbf{5}$ and 6 has not been observed during the NMR investigations. When the reaction was carried out in a 1:1 ratio between $\mathbf{5}$ and tert-butylisocyanate, the nucleophilic addition product $\mathrm{LAlH}(\mathrm{OCH}=\mathrm{N}-t \mathrm{Bu})(\mathbf{6}$, Scheme 3) was isolated. The analytical and spectroscopic data correspond with the formula of 6 . The band at $1868 \mathrm{~cm}^{-1}$ in the IR spectrum indicates the presence of an Al-H bond. ${ }^{10 \mathrm{~b}}$ The most intense peak in the EI mass spectrum of $\mathbf{6}$ appears at $m / z 544(M-\mathrm{H})^{+}$, and the peak at $\mathrm{m} / z 545(38 \%)$ is assigned to the molecular ion $M^{+}$. Compound 5 reacts with 2 or more equiv. of tert-butylisocyanate to afford the product $\mathrm{LAl}(\mathrm{OCH}=\mathrm{N}-t \mathrm{Bu})_{2}(\mathbf{7}$, Scheme 3$)$. Compound 7 was characterised by NMR and EI-MS, IR spectra, and elemental analysis, which are consistent with the composition depicted in Scheme 3. Al-H absorptions are absent in the IR spectrum. 
<smiles>CC(C)(C)N=CO[AlH]I</smiles>

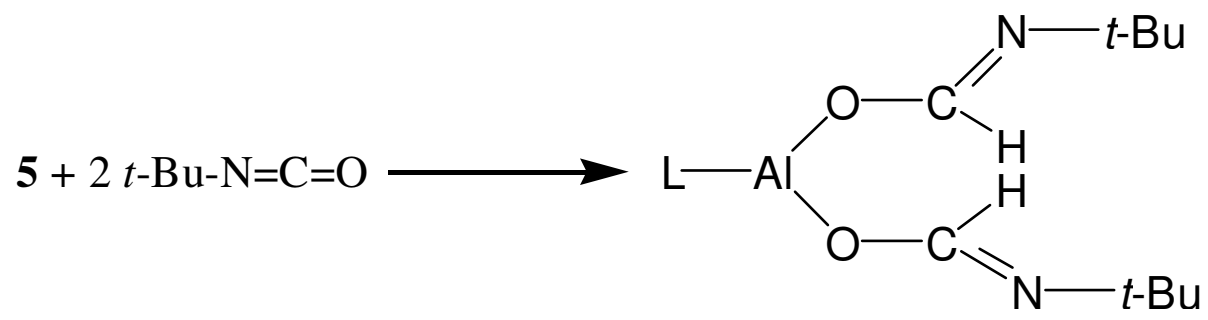

7

$\mathrm{L}=\mathrm{HC}(\mathrm{CMeNAr})_{2}, \mathrm{Ar}=2,6-i \mathrm{Pr}_{2} \mathrm{C}_{6} \mathrm{H}_{3}$

\section{Scheme 3}

\subsubsection{Preparation of aluminoxane hydroxide $\mathrm{LAI}(\mathrm{OH}) \mathrm{OAIL}(\mathrm{OCH}=\mathrm{N}-t \mathrm{Bu})(8)$}

The crude mixture of $\mathbf{5}$ and $\mathbf{6}$ was dissolved in pentane, and the resulting filtrate reacted with water when it was stored at $0{ }^{\circ} \mathrm{C}$ to obtain $\mathbf{8}$ as colorless crystals in low yield (Scheme 4). Compound $\mathbf{8}$ is soluble in common organic solvents such as pentane, hexane, toluene etc. The presence of the Al-OH bond was confirmed by IR $\left(v_{\mathrm{OH}} 3458 \mathrm{~cm}^{-1}\right)$ and ${ }^{1} \mathrm{H} \mathrm{NMR}\left(\delta_{\mathrm{H}}-0.30\right.$ ppm in $\mathrm{C}_{6} \mathrm{D}_{6}$ ). The resonance signal is in the range of that reported for the compound $\left.\left(\mathrm{Mes}_{3} \mathrm{Ga} \cdot \mathrm{OHLi}\right) \cdot 3 \mathrm{THF}\left(\delta_{\mathrm{H}}-0.56 \mathrm{ppm} \text { in THF-d }\right)_{8}\right){ }^{40 \mathrm{a}}$ Treatment of a mixture of 5 and $\mathbf{6}(1: 1$ molar ratio) with 2 equiv. of water in THF also led to 8 (Scheme 4a), an excess of water resulted in the decomposition of $\mathbf{8}$. A proposed mechanism for the formation of $\mathbf{8}$ is shown in Scheme $4 \mathrm{~b}$. In this reaction aluminumdihydroxide ${ }^{12 a}$ was obtained as an intermediate in the first step. Compound $\mathbf{6}$ can react cleanly with 1 equiv. of water, and the two products mixed 
together to yield $\mathbf{8}$ by elimination of water. $\mathbf{8}$ can also be prepared from $\mathbf{6}$ without adding compound 5 from the reaction between 6 and water in a 2:3 molar ratio. We believe that the coordination of the $\mathrm{OCH}=\mathrm{N}-t \mathrm{Bu}$ group and the bulky L ligand to the $\mathrm{Al}$ centre is essential for stabilising the $\mathrm{L}-\mathrm{Al}$ bond and the terminal reactive $\mathrm{OH}$ group of $\mathbf{8}$.

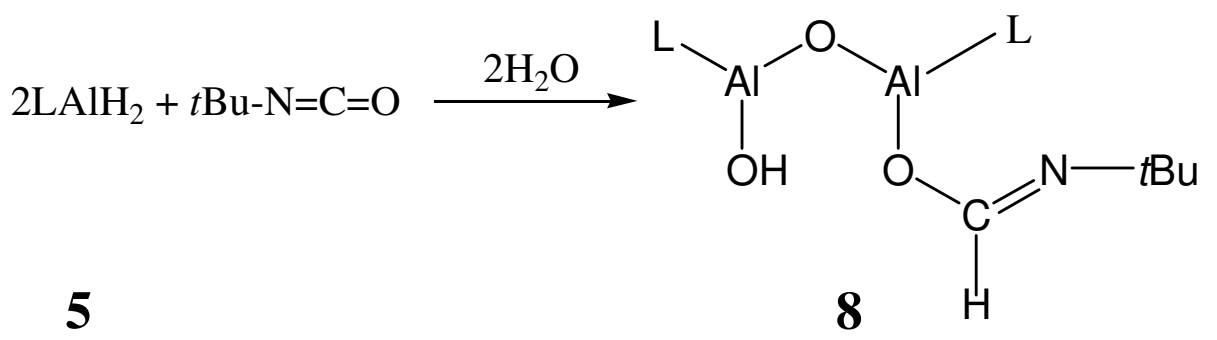

$$
5+6+2 \mathrm{H}_{2} \mathrm{O} \longrightarrow \mathbf{8}
$$

$\mathrm{L}=\mathrm{HC}(\mathrm{CMeNAr})_{2}, \mathrm{Ar}=2,6-i \mathrm{Pr}_{2} \mathrm{C}_{6} \mathrm{H}_{3}$

\section{Scheme 4a}<smiles>O[Al](O)[IH]C[Pb]</smiles>

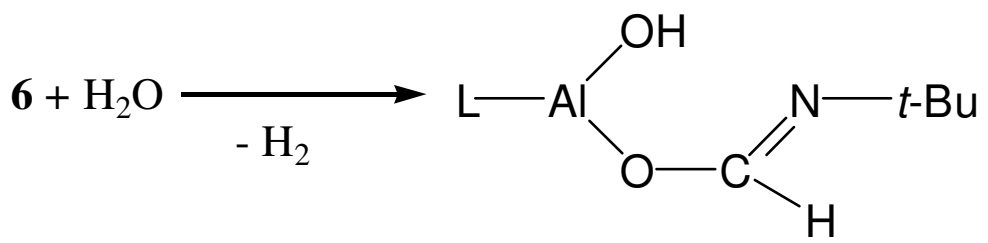<smiles>O[Al](O)C=N[Ga]O[Al](O)I</smiles>

$\mathrm{L}=\mathrm{HC}(\mathrm{CMeNAr})_{2}, \mathrm{Ar}=2,6-i \mathrm{Pr}_{2} \mathrm{C}_{6} \mathrm{H}_{3}$

\section{Scheme 4b}




\subsubsection{Molecular structure of 8}

Compound 8 crystallises in the monoclinic space group $P 2{ }_{1} / c$ with one molecule of pentane. As shown in Figure 4, 8 contains a bent $\mathrm{Al}-(\mu-\mathrm{O})-\mathrm{Al}$ unit with two tetrahedral distorted $\mathrm{Al}$ centres. $\mathrm{Al}(1)$ is surrounded by one terminal $\mathrm{OH}$ group, one bridging oxygen atom and two nitrogen atoms of the $\mathrm{L}$ ligand. The coordination sphere of $\mathrm{Al}(2)$ is completed by two nitrogen atoms of the ligand, one bridging oxygen atom, and one oxygen atom of the tert-butylisocyanate moiety. The selected bond lengths and angles are listed in Table 4. The

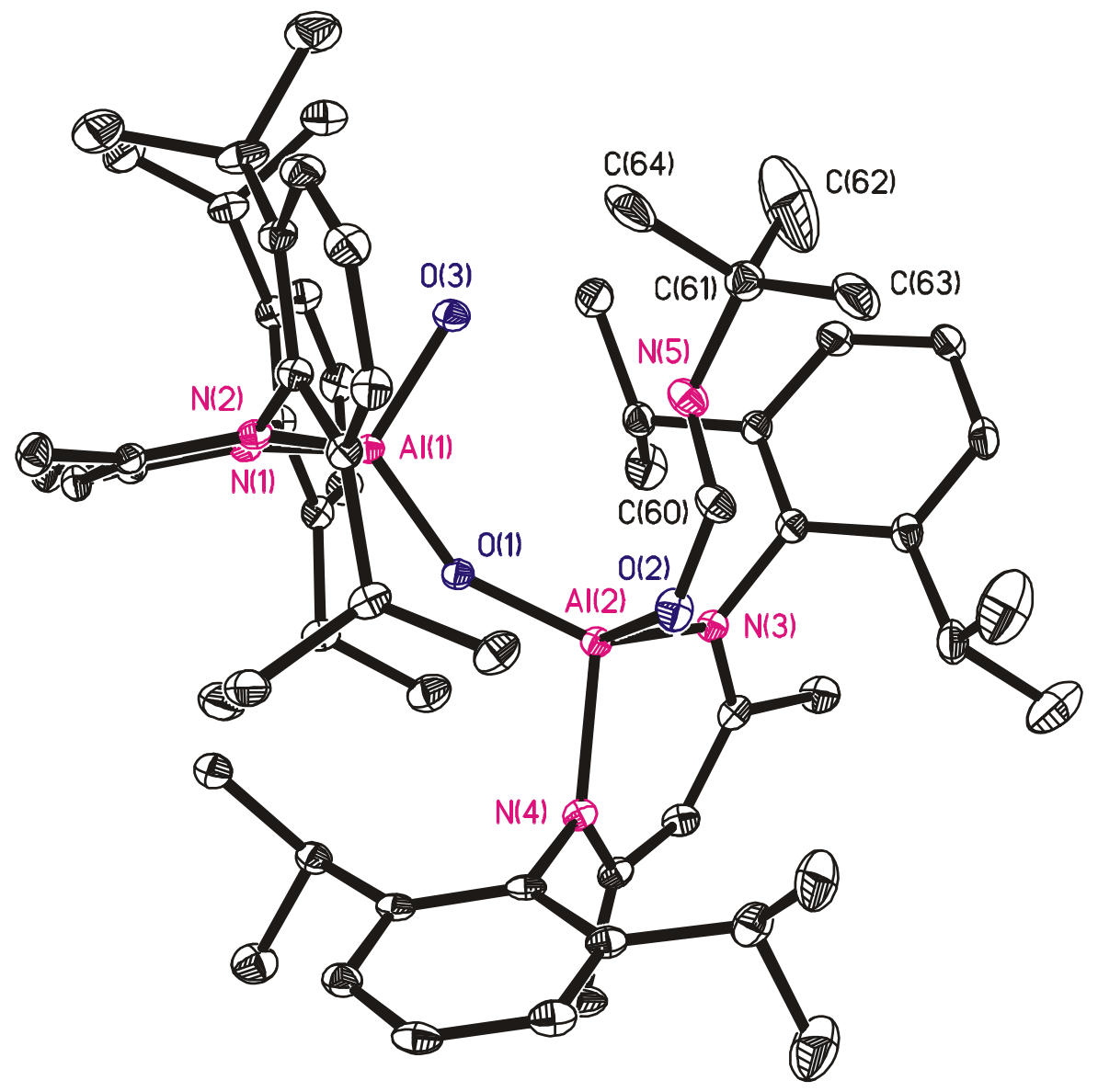

Figure 4. The crystal structure of $\mathbf{8}$. The hydrogen atoms of the $\mathrm{C}-\mathrm{H}$ bonds are omitted for clarity. 
Table 4. Selected bond lengths $(\AA)$ and angles $\left(^{\circ}\right)$ for 8 .

\begin{tabular}{llll}
\hline $\mathrm{Al}(1)-\mathrm{O}(1)$ & $1.699(2)$ & $\mathrm{O}(1)-\mathrm{Al}(1)-\mathrm{N}(2)$ & $119.83(9)$ \\
$\mathrm{Al}(1)-\mathrm{O}(3)$ & $1.727(2)$ & $\mathrm{O}(1)-\mathrm{Al}(1)-\mathrm{N}(1)$ & $111.34(9)$ \\
$\mathrm{Al}(1)-\mathrm{N}(2)$ & $1.926(2)$ & $\mathrm{O}(3)-\mathrm{Al}(1)-\mathrm{N}(1)$ & $109.57(10)$ \\
$\mathrm{Al}(1)-\mathrm{N}(1)$ & $1.932(2)$ & $\mathrm{N}(2)-\mathrm{Al}(1)-\mathrm{N}(1)$ & $94.94(10)$ \\
$\mathrm{Al}(2)-\mathrm{O}(1)$ & $1.706(2)$ & $\mathrm{O}(3)-\mathrm{Al}(1)-\mathrm{N}(2)$ & $107.33(9)$ \\
$\mathrm{Al}(2)-\mathrm{O}(2)$ & $1.739(2)$ & $\mathrm{O}(1)-\mathrm{Al}(2)-\mathrm{O}(2)$ & $114.38(9)$ \\
$\mathrm{Al}(2)-\mathrm{N}(3)$ & $1.930(2)$ & $\mathrm{O}(2)-\mathrm{Al}(2)-\mathrm{N}(3)$ & $106.18(10)$ \\
$\mathrm{Al}(2)-\mathrm{N}(4)$ & $1.911(2)$ & $\mathrm{O}(1)-\mathrm{Al}(2)-\mathrm{N}(4)$ & $110.11(10)$ \\
$\mathrm{O}(2)-\mathrm{C}(60)$ & $1.313(5)$ & $\mathrm{Al}(1)-\mathrm{O}(1)-\mathrm{Al}(2)$ & $147.85(10)$ \\
$\mathrm{C}(60)-\mathrm{N}(5)$ & $1.223(7)$ & $\mathrm{C}(60)-\mathrm{O}(2)-\mathrm{Al}(2)$ & $134.3(3)$ \\
$\mathrm{O}(3) \cdots \mathrm{N}(5)$ & $3.175(5)$ & $\mathrm{N}(5)-\mathrm{C}(60)-\mathrm{O}(2)$ & $123.7(5)$ \\
$\mathrm{O}(1)-\mathrm{Al}(1)-\mathrm{O}(3)$ & $112.35(9)$ & $\mathrm{C}(60)-\mathrm{N}(5)-\mathrm{C}(61)$ & $118.8(5)$ \\
\hline
\end{tabular}

dihedral angles are $30.20(24)^{\circ}$ for $\mathrm{O}(3)-\mathrm{Al}(1)-\mathrm{O}(1)-\mathrm{Al}(2)$ and $37.90(24)^{\circ}$ for $\mathrm{O}(2)-\mathrm{Al}(2)-\mathrm{O}(1)-\mathrm{Al}(1)$. The distance between $\mathrm{O}(3)$ and $\mathrm{N}(5)$ is $3.175(5) \AA$, which is only a little longer than the sum of their van der Waals radii, $3.07 \AA$ ( $\mathrm{N}$ is $1.55 \AA$ and $\mathrm{O}$ is $1.52 \AA) .{ }^{40 \mathrm{~b}}$ The $\mathrm{Al}(1)-\mathrm{OH}$ bond length $(1.727(2) \AA)$ is comparable to those in $\mathrm{LAl}(\mathrm{OH})_{2}(1.6947(15)$ and $1.7107(16) \AA),{ }^{12 \mathrm{a}}$ and significantly shorter than those of $\mathrm{Al}-(\mu-\mathrm{OH})$ and $\mathrm{Al}-\left(\mu_{3}-\mathrm{OH}\right)$ bonds in $\left[(t \mathrm{Bu})_{2} \mathrm{Al}(\mu-\mathrm{OH})\right]_{3} \quad(1.848 \quad \AA),{ }^{9 \mathrm{c}} \quad$ and $\quad\left[\mathrm{Al}_{5}(t \mathrm{Bu})_{5}\left(\mu_{3}-\mathrm{O}\right)_{2}\left(\mu_{3}-\mathrm{OH}\right)_{2}(\mu-\mathrm{OH})_{2}\left(\mu-\mathrm{O}_{2} \mathrm{CPh}\right)_{2}\right]$ (Al- $(\mu-\mathrm{OH}) 1.820(3)$ to $1.828(3) \AA$; $\mathrm{Al}-\left(\mu_{3}-\mathrm{OH}\right) 1.914(5)$ to $\left.2.086(4) \AA\right) .{ }^{41}$ The $\mathrm{Al}-(\mu-\mathrm{O})$ bond length of $8(1.703 \AA)$ is similar to those of the compounds $\left[(t \mathrm{Bu})_{2} \mathrm{Al}(\mathrm{py})_{2}\right]_{2}(\mu-\mathrm{O})(1.710 \AA)^{9 \mathrm{c}}$ and $\left[\left\{(t \mathrm{Bu})_{2} \mathrm{Al}\left(\mathrm{NH}(\mathrm{Me}) \mathrm{CH}_{2} \mathrm{CH}_{2} \mathrm{NMe}_{2}\right)\right\}_{2}(\mu-\mathrm{O})\right](1.690(7) \text { and 1.714(7) } \AA)^{42}$ The $\mathrm{Al}(2)-\mathrm{O}(2)$ bond length $(1.739(2) \AA)$ in $\mathbf{8}$ is slightly longer than those of the Al-OH (1.727(2) $\AA$ ) and 
Al- $(\mu-\mathrm{O})(1.703 \AA)$. The Al-N bond lengths (from 1.912(2) to 1.931(2) $\AA$, av. $1.925 \AA$ ) are within the range of those previously observed ( $\mathrm{LAlMe}_{2}$ av. $\left.1.922 \AA\right) .{ }^{43}$

\subsubsection{Theoretical calculation of 8}

A broad band at $3458 \mathrm{~cm}^{-1}$ was observed in the IR spectrum of $\mathbf{8}$, assigned to the $\mathrm{OH}$ stretch. ${ }^{12 \mathrm{a}}$ Therefore, we believe that there is an intra- or intermolecular hydrogen bond in the solid state structure of $\mathbf{8}$. However, we cannot find the proton position in the X-ray structural analysis of 8. Theoretical calculations, based on the DFT method RI-BP86/SV $(\mathrm{P})^{44}$ within Turbomole, ${ }^{45}$ were carried out to verify the existence of the $\mathrm{H}$ atom and investigate its character. The four $\mathrm{CHMe}_{2}$ groups which are far away from $\mathrm{O}(3)$ were replaced by $\mathrm{H}$ during the calculation in order to reduce the computer time. The full geometry optimisation was carried out for both compound $\mathbf{8}$ with $\mathrm{H}$ and without the $\mathrm{H}$ atom. The calculations proved the existence of the $\mathrm{H}$ atom in compound 8: with $\mathrm{H}$ in the optimised geometry the distance of $\mathrm{O}(3) \cdots \mathrm{N}(5)$ is $2.93 \AA$ and close to that of the X-ray structure $(3.175(5) \AA$ ), while without $\mathrm{H}$ the optimised $\mathrm{O}(3) \cdots \mathrm{N}(5)$ distance is $5.87 \AA$. Also the structure of compound $\mathbf{8}$ with the $\mathrm{H}$ atom is more similar to that of the X-ray structure (mean deviation for all Al bonds: $0.02 \AA$, bond angles: $3.3^{\circ}$ ) than without $\mathrm{H}$ (mean deviation for all $\mathrm{Al}$ bond lengths: $0.05 \AA$, bond angles: $5.7^{\circ}$.

The calculated result shows that there is a strong $\mathrm{O}-\mathrm{H} \cdots \mathrm{N}$ hydrogen bond ${ }^{46}$ between the $\mathrm{OH}$ group and the $\mathrm{N}$ atom of the $\mathrm{O}-\mathrm{CH}=\mathrm{N}-\mathrm{t}$ Bu moiety $(\mathrm{H}-\mathrm{O} 1.00 \AA, \mathrm{H} \cdots \mathrm{N} 1.93 \AA$, O-H $\cdots \mathrm{N}$ $172.6^{\circ}, \mathrm{H}-\mathrm{O}-\mathrm{Al} 110.1^{\circ}$ ) in agreement with the IR spectrum of $\mathbf{8}$. Furthermore, as shown in Figure 5, the formation of the intramolecular $\mathrm{O}-\mathrm{H} \cdots \mathrm{N}$ hydrogen bond leads to good shielding 
of the $\mathrm{OH}$ group from the bulky $t \mathrm{Bu}$ group, and the $\mathrm{O}-\mathrm{CH}=\mathrm{N}-t \mathrm{Bu}$ moiety will be far away from $\mathrm{O}(3)$ if the $\mathrm{H}$ atom is not present (as mentioned above in this case $\mathrm{r}(\mathrm{O}(3) \cdots \mathrm{N}(5))=5.87$ $\AA$ ). This shielding together with the bulky L ligand on the $\mathrm{Al}$ atom protects the $\mathrm{OH}$ group from attack by another Lewis acidic Al center. Obviously that is the reason why the binuclear terminal hydroxide-containing $\mathbf{8}$ does not aggregate to larger clusters.
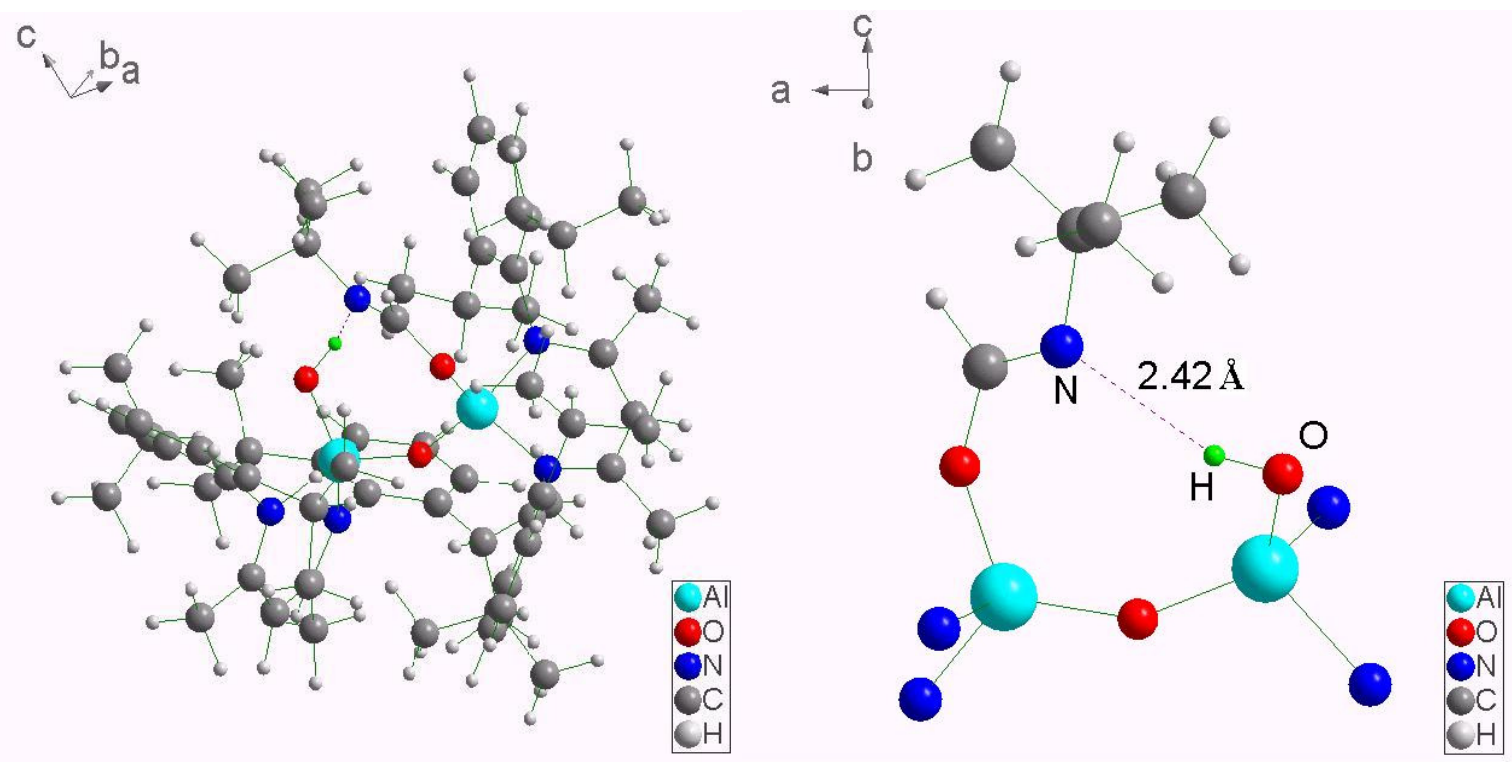

Figure 5. The intramolecular hydrogen bond in compound $\mathbf{8}$. The position of the $\mathrm{H}$ atom (green) was obtained by AM1 geometry optimisation. Left: The position of $\mathrm{H}(\mathrm{O})$ in the whole molecule. Right: the local region of the intramolecular hydrogen bond.

In summary, we describe a new method for the synthesis of an aluminoxane hydroxide by the direct hydrolysis of aluminum hydrides with water. The intramolecular hydrogen bond and the bulky L ligand on the $\mathrm{Al}$ atom stabilise the reactive terminal $\mathrm{OH}$ group in $\mathbf{8 . 8}$ should react with other less bulky organometallic compounds in solution, which provides the 
possibility for the synthesis of aluminum containing homo- or heteroorganometallic compounds and their application for the polymerization of olefins.

\subsection{Synthesis and reactions of $\mathrm{Al}-\mathrm{N}$ and $\mathrm{Al}-\mathrm{C}-\mathrm{N}$ clusters}

Compounds containing Al-N bonds have attracted much attention due to their application in catalysis, ${ }^{17}$ as synthetic intermediates, ${ }^{18}$ and as potential precursor for the chemical vapour deposition of aluminum nitride. ${ }^{16} \mathrm{Al}-\mathrm{N}$ rings and clusters have been reviewed recently. ${ }^{47} \mathrm{In}$ 1973, J. D. Smith et al. reported the first heptameric aluminum imide (MeAlNMe $)_{7}$ structurally characterised by X-ray diffraction methods which was obtained from the thermal decomposition of the adduct $\mathrm{Me}_{3} \mathrm{Al} \cdot \mathrm{NH}_{2} \mathrm{Me}$ in toluene at $215^{\circ} \mathrm{C} .{ }^{48-49}$ However, neither yields nor further reactivity have been reported. Additionally, the preparation, NMR spectra and the mass spectrum of $(\text { EtAlNMe })_{\mathrm{n}}$ were mentioned, ${ }^{49-50}$ and based on these limited data alone it was thought to be an octamer, its unambiguous geometry has never been reported. The degree of oligomerisation of these thermal decomposition products is dependent on the temperature of thermolysis and the substituents on nitrogen. ${ }^{51}$ To the best of our knowledge no other heptameric aluminum imide has been structurally characterized. More attention was paid to organoaluminum fluorides due to the potential importance ${ }^{52 a}$ of these compounds as models for certain catalytic reactions. Pioneering work on organoaluminum fluorides has been achieved by $\mathrm{K}$. Ziegler et al. who reported the reactions of $\mathrm{NaF}$ with $\mathrm{Et}_{3} \mathrm{Al}$ and $\mathrm{Me}_{2} \mathrm{AlCl}$ to yield $\mathrm{Na}^{+}$salts of anionic fluoride species $\left(\mathrm{Et}_{3} \mathrm{AlF}\right)^{-},\left[\left(\mathrm{Et}_{3} \mathrm{Al}\right)_{2}(\mu-\mathrm{F})\right]^{-}$and $\left(\mathrm{Me}_{2} \mathrm{AlF}_{2}\right)^{-}$ respectively in $1955 .{ }^{5 \mathrm{~b}}$ Reviews on organoaluminum fluorides have been published by $\mathrm{J}$. Weidlein $^{52 \mathrm{c}}$ and by H. W. Roesky et al. ${ }^{52 \mathrm{~d}}$ Several compounds containing both terminal and 
bridging $\mathrm{Al}-\mathrm{F}$ bonds ${ }^{53-55}$ or only bridging $\mathrm{Al}-\mathrm{F}-\mathrm{Al}$ bonds ${ }^{56}$ are known, and some others with

Al-F-M $(\mathrm{M}=\mathrm{Li}, \mathrm{Na}, \mathrm{K}, \mathrm{Ti}, \mathrm{Zr})^{57}$ building units are also reported. The number of compounds having only terminal Al-F bonds is limited. ${ }^{58-60}$ However, no chemistry of aggregates containing only terminal Al-F bonds is known so far. Herein we report an efficient synthetic route involving the reaction of $\mathrm{RCN}\left(\mathrm{R}=1\right.$-adamantyl) with an excess of $\mathrm{AlH}_{3} \cdot \mathrm{NMe}_{3}$ in boiling toluene to form the first $\left(\mathrm{RCH}_{2} \mathrm{NAlH}\right)_{7}$ (9) compound containing $\mathrm{Al}-\mathrm{H}$ bonds, and the fluorination of the $\mathrm{Al}_{7} \mathrm{~N}_{7}$ and $\mathrm{Al}_{4} \mathrm{C}_{4} \mathrm{~N}_{4}$ species to get the first two aggregates $\left(\mathrm{RCH}_{2} \mathrm{NAl}\right)_{7} \mathrm{~F}_{2.26} \mathrm{H}_{4.74}(\mathbf{1 0})$ and $\left(t \mathrm{BuNCH}_{2} \mathrm{AlF}\right)_{4}(\mathbf{1 1})$ containing only terminal Al-F bonds.

\subsubsection{Preparation and reactions of the novel heptameric aluminum imides 9 and 10}

The reaction between $\mathrm{RCN}$ and 1.5 equiv. of $\mathrm{AlH}_{3} \cdot \mathrm{NMe}_{3}$ in boiling toluene resulted in the formation of compound 9 , while 9 reacted with 7 equiv. of $\mathrm{Me}_{3} \mathrm{SnF}$ in refluxing toluene to afford compound $\mathbf{1 0}$ (Scheme 5). For the synthesis of $\mathbf{9}$ we followed the procedure for the preparation of hexameric aluminum imides $\left(\mathrm{RCH}_{2} \mathrm{NAlH}\right)_{6}$ with various $\mathrm{R}$ groups $(\mathrm{R}=\mathrm{Ph}$, $\left.p-\mathrm{MeC}_{6} \mathrm{H}_{4}, p-\mathrm{CF}_{3} \mathrm{C}_{6} \mathrm{H}_{4}\right){ }^{20 \mathrm{~b}}$

The IR spectrum of compound 9 shows strong bands in the region from 1851 to 1916 $\mathrm{cm}^{-1}$ due to Al-H stretching frequencies, ${ }^{61}$ and just a weak band at $1895 \mathrm{~cm}^{-1}$ attributed to the non-substituted $\mathrm{Al}-\mathrm{H}$ bond in $\mathbf{1 0}$ is present. In the ${ }^{27} \mathrm{Al}$ NMR spectra of $\mathbf{9}$ and $\mathbf{1 0}$ no resonances were detected due to the quadrupole moment of aluminum. In the case of the hexameric aluminum imides $\left(\mathrm{RCH}_{2} \mathrm{NAlH}\right)_{6}\left(\mathrm{R}=\mathrm{Ph}, p-\mathrm{MeC}_{6} \mathrm{H}_{4}, p-\mathrm{CF}_{3} \mathrm{C}_{6} \mathrm{H}_{4}\right),{ }^{20 \mathrm{~b}}$ there is only one resonance in the ${ }^{1} \mathrm{H}$ NMR spectrum at about 4.2 ppm for the $\mathrm{CH}_{2}$ group connecting the $\mathrm{R}$ group and nitrogen atom, whereas in compounds $\mathbf{9}$ and $\mathbf{1 0}$ there are 3 and 6 singlets 
respectively ranging from 2.76 to $3.08 \mathrm{ppm}$ due to the environmentally different arranged hydrogen atoms. The increase of singlets for the $\mathrm{CH}_{2}$ group going from $\mathbf{9}$ to $\mathbf{1 0}$ is due to the partially fluorinated $\mathrm{Al}-\mathrm{H}$ groups resulting in a more differentiated environment.

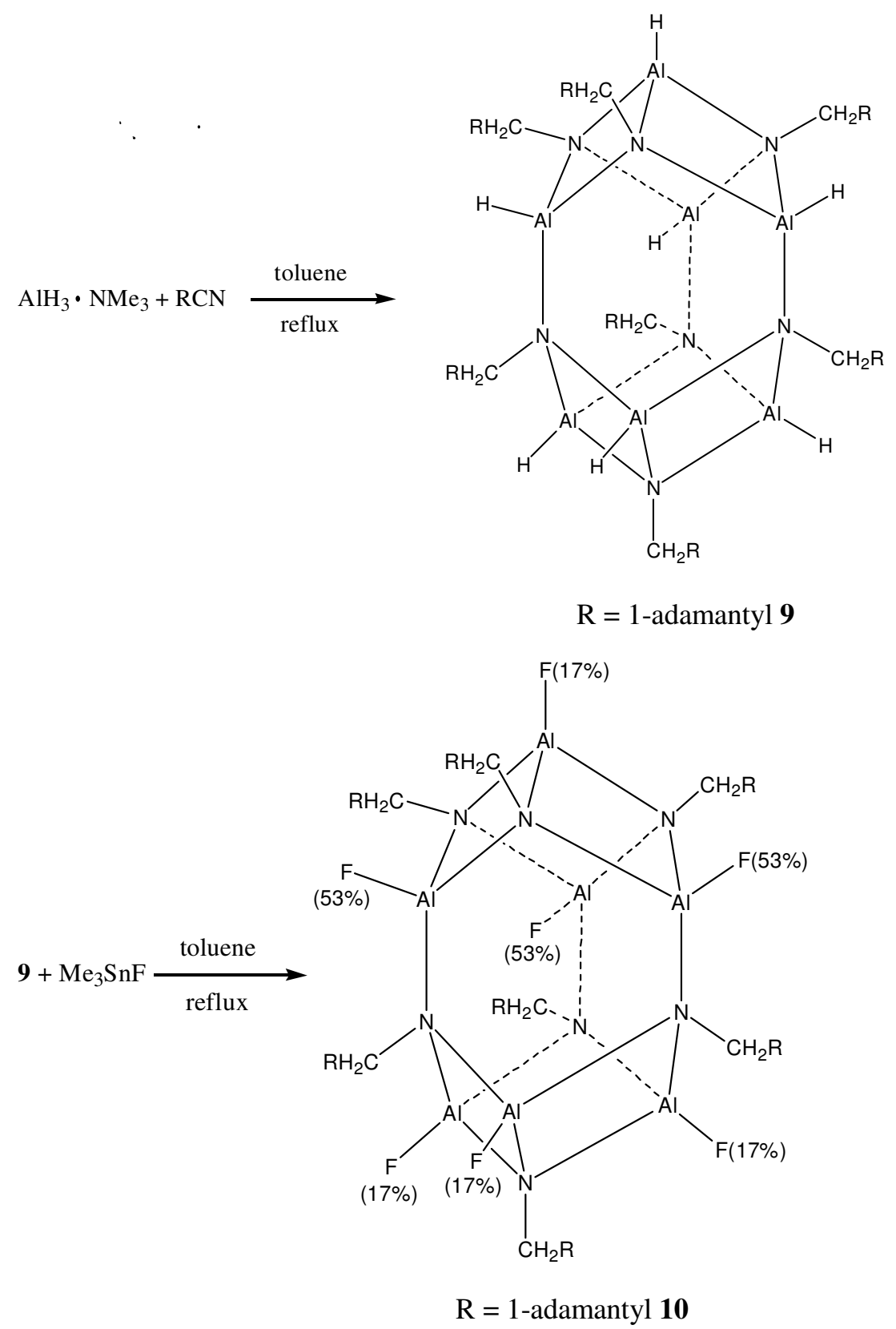

\section{Scheme 5}

Compound 10 was prepared from 9 using $\mathrm{Me}_{3} \mathrm{SnF}$ as a fluorinating agent (Scheme 5). 
This metathesis reaction resulted in the formation of $\mathrm{Me}_{3} \mathrm{SnH}$. Compound $\mathbf{1 0}$ is a partially fluorinated derivative. In order to obtain a complete fluorination product, we used $\mathrm{Me}_{3} \mathrm{SnF}$ in excess (molar ratio 1:8) in refluxing toluene or alternatively tried the reaction at room temperature in $\mathrm{CH}_{2} \mathrm{Cl}_{2}$. In both cases the IR spectra contained no $\mathrm{Al}-\mathrm{H}$ stretching frequencies. However, a complex mixture of products (as seen from ${ }^{1} \mathrm{H}$ and ${ }^{19} \mathrm{~F}$ NMR spectra) was formed. It is noteworthy that an excess of $\mathrm{Me}_{3} \mathrm{SnF}$ or other attempts to achieve a higher degree of fluorination of $\mathbf{1 0}$ leads to the destruction of the core structure. We also examined the reactions of 9 with $\mathrm{Me}_{3} \mathrm{SiCl}$ and $\mathrm{Me}_{3} \mathrm{SiBr}$ in boiling toluene. In both cases partially substituted products were obtained as deduced from the IR spectra. In contrast, the metathesis reactions of hexameric aluminum imide $\left(\mathrm{PhCH}_{2} \mathrm{NAlH}\right)_{6}{ }^{20 \mathrm{~b}}$ with $\mathrm{Me}_{3} \mathrm{SiBr}$ and $\mathrm{PhC} \equiv \mathrm{CH}$ proceeded smoothly to give the completely substituted products.

The electronegativity of the $\mathrm{H}$ atom is a little higher than that of the $\mathrm{Al}$ atom, therefore it is slightly negatively charged in Al-H bonds, and correspondingly the core is slightly positive charged (Here we omit the effect of the ligand as it plays the same role throughout the discussion). When $\mathrm{H}$ is substituted by an atom with a larger electronegativity such as halogens, the core becomes more positive and shows significant internal electrostatic repulsion. This type of electrostatic repulsion reduces the stability of the core, and if exceeding to some extent the core will decompose. We think this is the reason why only partially $\mathrm{F}, \mathrm{Cl}$ and $\mathrm{Br}$ substituted products are obtained. In the case of complete substitution, the internal electrostatic repulsion grows with the increase of the size of the core, and the electronegativity of the substituting atoms. Therefore the order of completely substituted species is expected to be: larger core $<$ smaller core, $\mathrm{F}<\mathrm{Cl}<\mathrm{Br}<\mathrm{I}<\mathrm{R}$ group. This assumption agrees with the 
experimental results found so far, as for small cores there are some completely fluorine substituted compounds reported, such as complex 11, while for large cores (more than $5 \mathrm{Al}$ atoms) none was known.

\subsubsection{Molecular structures of 9 and 10}

The molecular structure of compound 9 is shown in Figure 6. Compound 9 crystallises in the triclinic space group $P \overline{1}$ with one molecule of toluene. Selected bond lengths and angles for 9 are shown in Table 5. From the molecular structure it can be seen that $\mathrm{Al}(1), \operatorname{Al}(2)$ and $\mathrm{Al}(3)$ form a regular triangle while $\mathrm{Al}(4), \mathrm{Al}(5)$ and $\mathrm{Al}(6)$ are arranged in a larger regular triangle paralleling the first one but is rotated by $60^{\circ}$. The $\mathrm{Al}(1), \operatorname{Al}(2)$ and $\mathrm{Al}(3)$ triangle is capped by $\mathrm{N}(7)$, and $\mathrm{Al}(7)$ is capping the $\mathrm{Al}(4), \mathrm{Al}(5)$ and $\mathrm{Al}(6)$ triangle. Each plane of the $\mathrm{Al}$ triangle on the surface of the cluster is capped by a $\mathrm{N}$ atom except those formed by two $\mathrm{Al}$ atoms from the larger regular triangle and one $\mathrm{Al}$ atom from the smaller one. The $\mathrm{Al}_{7} \mathrm{~N}_{7}$ core has an approximate $C_{3 v}$ symmetry, and the $C_{3}$ axis lies along $\mathrm{Al}(7)$ and $\mathrm{N}(7)$. After including the $\mathrm{CH}_{2} \mathrm{R}$ group, the molecule has $C_{1}$ symmetry. The $\mathrm{Al}$ atoms have a coordination number of four surrounded by three $\mathrm{N}$ atoms and one $\mathrm{H}$ atom (the electron density of $\mathrm{H}$ is too weak to be detected by the $\mathrm{X}$-ray analysis). Each $\mathrm{N}$ atom connects three $\mathrm{Al}$ atoms and one $\mathrm{CH}_{2} \mathrm{R}$ group thus forming a cage structure. All the $\mathrm{CH}_{2} \mathrm{R}$ groups are located outside of the cage. Al-N bond lengths of different Al-N cage compounds are given in Table 6. From Table 6 it can be seen that the mean Al-N bond length (1.930 $\AA$ ) of 9 is comparable to those found in tetrameric, hexameric, heptameric and octameric aluminum imides due to the similar coordination environment within the cage where each $\mathrm{Al}$ atom is connected with three $\mathrm{N}$ atoms and each $\mathrm{N}$ 
atom binds to three $\mathrm{Al}$ atoms.

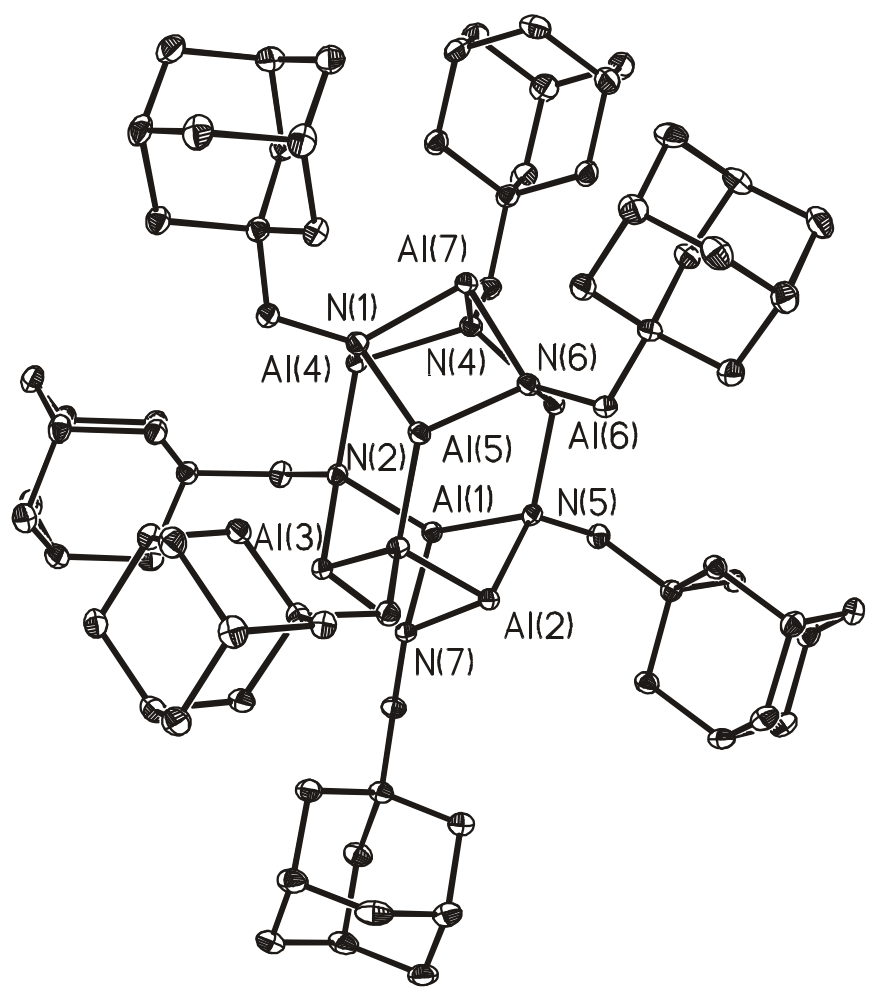

Figure 6. The crystal structure of 9 (50\% probability). Hydrogen atoms and toluene molecule have been omitted for clarity.
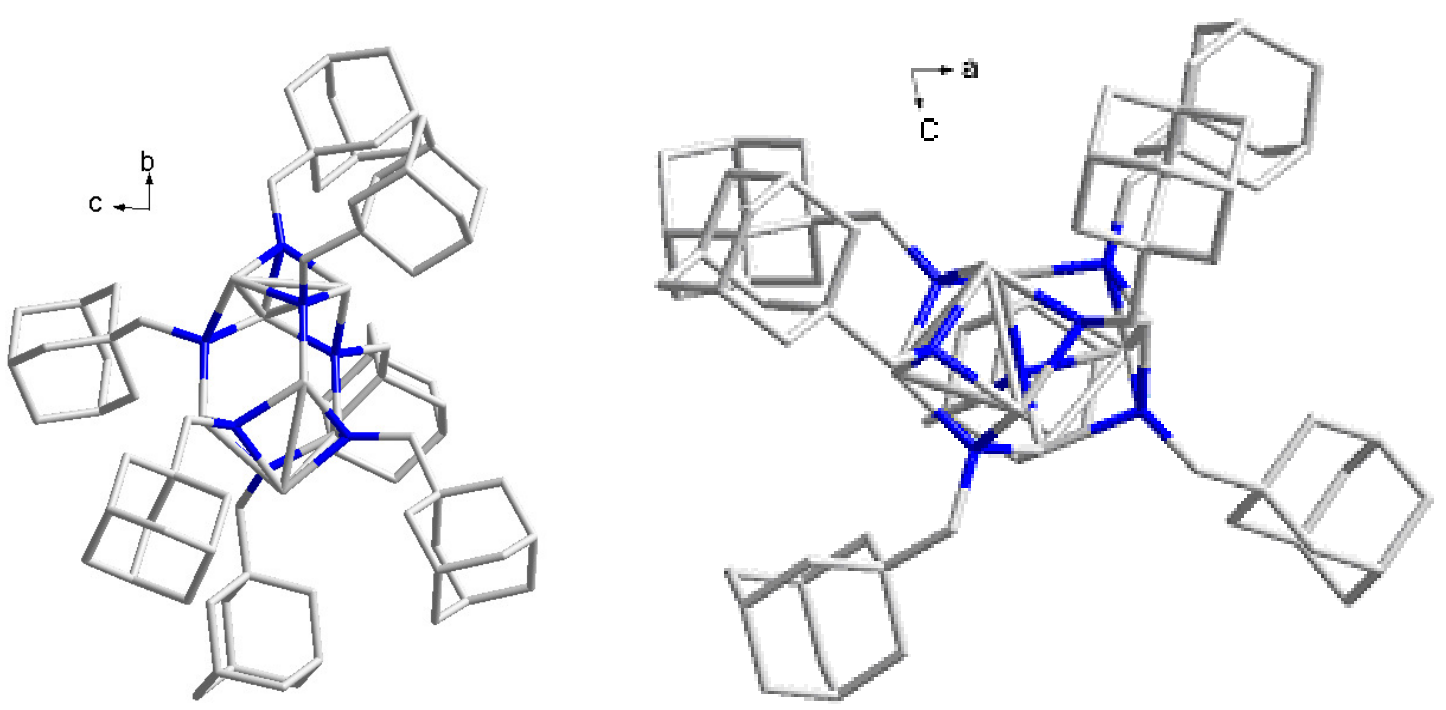


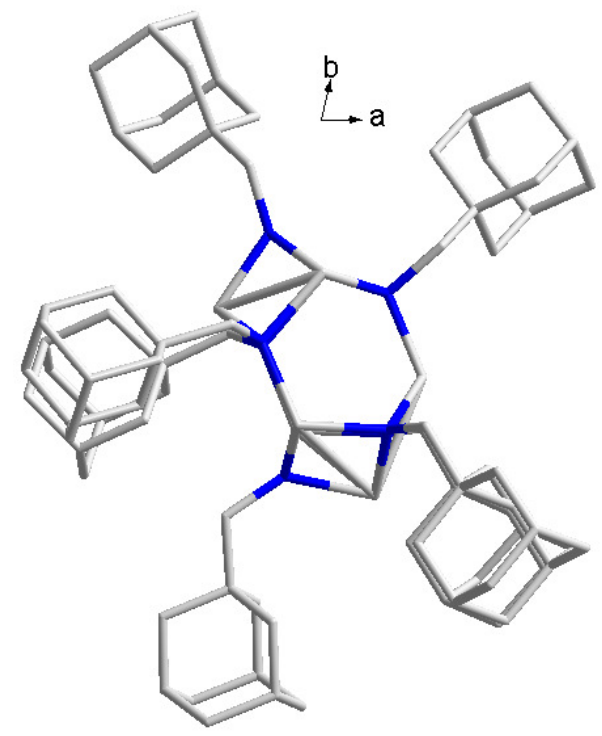

Figure 7. Core structure of 9 viewed along a, b, c directions.

Table 5. Selected bond lengths $(\AA)$ and angles $\left({ }^{\circ}\right)$ for 9.

\begin{tabular}{lllr}
\hline $\mathrm{Al}(1)-\mathrm{N}(7)$ & $1.937(2)$ & $\mathrm{N}(7)-\mathrm{Al}(1)-\mathrm{N}(2)$ & $91.87(9)$ \\
$\mathrm{Al}(1)-\mathrm{N}(2)$ & $1.943(2)$ & $\mathrm{N}(2)-\mathrm{Al}(4)-\mathrm{N}(1)$ & $113.92(8)$ \\
$\mathrm{Al}(1)-\mathrm{N}(5)$ & $1.940(2)$ & $\mathrm{N}(1)-\mathrm{Al}(4)-\mathrm{N}(4)$ & $90.63(8)$ \\
$\mathrm{Al}(4)-\mathrm{N}(2)$ & $1.911(2)$ & $\mathrm{N}(2)-\mathrm{Al}(4)-\mathrm{N}(4)$ & $115.37(9)$ \\
$\mathrm{Al}(4)-\mathrm{N}(1)$ & $1.920(2)$ & $\mathrm{N}(6)-\mathrm{Al}(7)-\mathrm{N}(4)$ & $89.03(9)$ \\
$\mathrm{Al}(4)-\mathrm{N}(4)$ & $1.928(2)$ & $\mathrm{Al}(1)-\mathrm{N}(2)-\mathrm{Al}(3)$ & $86.84(9)$ \\
$\mathrm{Al}(7)-\mathrm{N}(1)$ & $1.941(2)$ & $\mathrm{Al}(4)-\mathrm{N}(2)-\mathrm{Al}(1)$ & $115.35(9)$ \\
$\mathrm{Al}(7)-\mathrm{N}(4)$ & $1.930(2)$ & $\mathrm{Al}(4)-\mathrm{N}(2)-\mathrm{Al}(3)$ & $123.57(9)$ \\
$\mathrm{Al}(7)-\mathrm{N}(6)$ & $1.918(2)$ & $\mathrm{Al}(6)-\mathrm{N}(4)-\mathrm{Al}(4)$ & $115.95(10)$ \\
$\mathrm{N}(1)-\mathrm{C}(75)$ & $1.498(3)$ & $\mathrm{Al}(4)-\mathrm{N}(4)-\mathrm{Al}(7)$ & $88.57(9)$ \\
$\mathrm{N}(7)-\mathrm{Al}(1)-\mathrm{N}(5)$ & $91.64(8)$ & $\mathrm{Al}(6)-\mathrm{N}(4)-\mathrm{Al}(7)$ & $88.21(9)$ \\
$\mathrm{N}(5)-\mathrm{Al}(1)-\mathrm{N}(2)$ & $112.70(8)$ & $\mathrm{Al}(2)-\mathrm{N}(7)-\mathrm{Al}(1)$ & $86.91(7)$ \\
\hline
\end{tabular}


Table 6. Al-N bond lengths $(\AA)$ of different Al-N cage compounds

\begin{tabular}{|c|c|c|}
\hline Compound & range of Al-N bond lengths & av Al-N bond lengths \\
\hline$(i \mathrm{PrNAlH})_{4}^{22 \mathrm{a}}$ & $1.897-1.923$ & 1.914 \\
\hline$(i \mathrm{PrNAlMe})_{4}^{22 \mathrm{a}}$ & $1.917-1.932$ & 1.923 \\
\hline$\left(4-\mathrm{C}_{6} \mathrm{H}_{4} \mathrm{FNAlMe}\right)_{4}{ }^{62}$ & $1.922-1.951$ & 1.934 \\
\hline$(\mathrm{PhNAlPh})_{4}{ }^{63}$ & $1.900-1.930$ & 1.914 \\
\hline$(n-\mathrm{PrNAlH})_{6}{ }^{22 \mathrm{~b}}$ & $1.884-1.972$ & 1.913 \\
\hline$\left(p-\mathrm{CF}_{3} \mathrm{C}_{6} \mathrm{H}_{4} \mathrm{CH}_{2} \mathrm{NalH}\right)_{6}{ }^{20 \mathrm{~b}}$ & $1.880-1.980$ & 1.919 \\
\hline$\left(\mathrm{PhCH}_{2} \mathrm{NalH}\right)_{6}^{20 b}$ & $1.886-1.974$ & 1.918 \\
\hline$(\mathrm{PhNAlMe})_{6}^{64}$ & $1.902-1.951$ & 1.925 \\
\hline$(\mathrm{MeNAlMe})_{7}{ }^{49}$ & $1.810-1.970$ & 1.910 \\
\hline$\left(1-\mathrm{AdCH}_{2} \mathrm{NAlH}\right)_{7}{ }^{*}$ & $1.900-1.980$ & 1.930 \\
\hline$(n-\mathrm{PrNAlH})_{8}{ }^{22 \mathrm{~b}}$ & $1.878-1.947$ & 1.916 \\
\hline
\end{tabular}

* this work

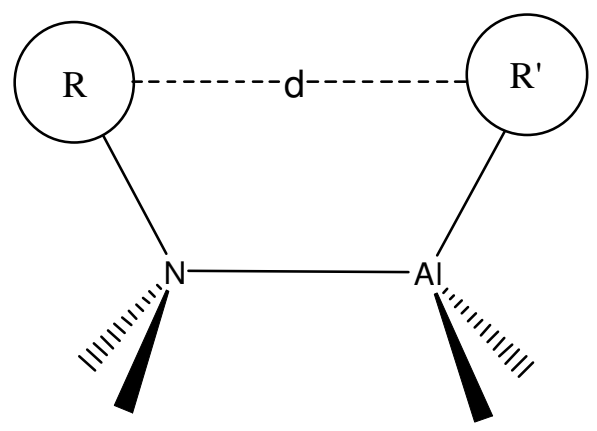

\section{Scheme 6}

Scheme 6 shows a sector of the general structure of compound $\left(\text { RNAlR }^{\prime}\right)_{n}(n=4,6$ and 7). With longer $d$ ( $d$ is the distance between $R$ and $R^{\prime}$ groups) the interaction between $R$ and $R^{\prime}$ groups decreases. The steric interaction in $\left(R_{N A l R}\right)_{n}$ is significant for larger $R$ and $R^{\prime}$ groups. The number $\mathrm{n}$ for compounds $\left(\mathrm{RNAlR}^{\prime}\right)_{\mathrm{n}}$ is highly dependent on the bulkiness of the $\mathrm{R}$ and $\mathrm{R}^{\prime}$ groups, for large $\mathrm{R}$ and $\mathrm{R}^{\prime}$ groups small $\mathrm{n}$ values are found (see the compounds listed in Table 6 and some other compounds such as $(\mathrm{ArNAlPh})_{4}\left(\mathrm{Ar}=3-\mathrm{MeC}_{6} \mathrm{H}_{4}, 4-\mathrm{XC}_{6} \mathrm{H}_{4}\right.$ 
$(\mathrm{X}=\mathrm{Me}, \mathrm{OMe}, \mathrm{Cl} \text { or I) })^{65}$ and $(t \mathrm{BuNAlEt})_{4} \cdot{ }^{50} \mathrm{In}$ compounds $(\mathrm{RNAlX})_{\mathrm{n}}(\mathrm{X}=\mathrm{H}, \mathrm{F}, \mathrm{Br}) \mathrm{X}$ is smaller compared to the $\mathrm{R}^{\prime}$ group of $\left(\mathrm{RNAlR}^{\prime}\right)_{\mathrm{n}}$. Therefore compounds with large $\mathrm{R}$ groups form bigger Al-N cores due to a minimum interaction of $\mathrm{R}$ with the $\mathrm{X}$ atom. For different sizes of $\mathrm{n}$ it is quite difficult to evaluate the steric interaction between two $\mathrm{R}$ groups using a simple model. Therefore we report herein on a heptamer $(\mathrm{R}=1$-adamantyl $)$ less common than a hexamer. If the $\mathrm{Ph}$ groups in $\left(\mathrm{PhCH}_{2} \mathrm{NAlH}\right)_{6}{ }^{20 \mathrm{~b}}$ are replaced by 1 -adamantyl groups, calculations give a minimum C …C distance of $2.95 \AA$ for two adjacent 1-adamantyl groups. Compared with the van der Waals radius for carbon $(1.7 \AA)$, however, the distance of $2.95 \AA$ is obviously too short. Consequently the formation of a heptameric compound $\mathbf{9}$ instead of the corresponding hexamer is observed.

Single crystals of $\mathbf{1 0}$ were obtained from the reaction mixture in toluene. $\mathbf{1 0}$ crystallises in the triclinic space group $P \overline{1}$ with one molecule of toluene in the unit cell. The molecular structure of $\mathbf{1 0}$ is depicted in Figure 8. From the structure it is seen that the $\mathrm{Al}_{7} \mathrm{~N}_{7}$ core is retained. The $\mathrm{X}$-ray analysis of compound $\mathbf{1 0}$ was refined with an occupancy factor of $53 \%$ for $\mathrm{F}(1), \mathrm{F}(2)$ and $F(3)$, while the other four fluorine atoms $F(20), F(21), F(22)$ and $F(23)$ have each an occupancy factor of $17 \%$. The remainder are non-replaced hydrogen atoms. Selected bond lengths and angles for $\mathbf{1 0}$ are listed in Table 7. The Al-F bond distances are $1.63 \AA$ for $\mathrm{F}(1)$, $F(2)$, and $F(3)$, and $1.52 \AA$ for $F(20), F(21), F(22)$ and $F(23)$. Both are shorter than the Al-F bonds (terminal) in $\left[\left(\mathrm{Me}_{3} \mathrm{Si}\right)_{3} \mathrm{CAlF}_{2}\right]_{3}(1.657-1.681 \AA)^{54}$ due to the incomplete fluorination of 10. The average Al-N bond length of $1.920 \AA$ is shorter than that in 9 presumably due to the strong electron-withdrawing capability of the fluorine atoms. 


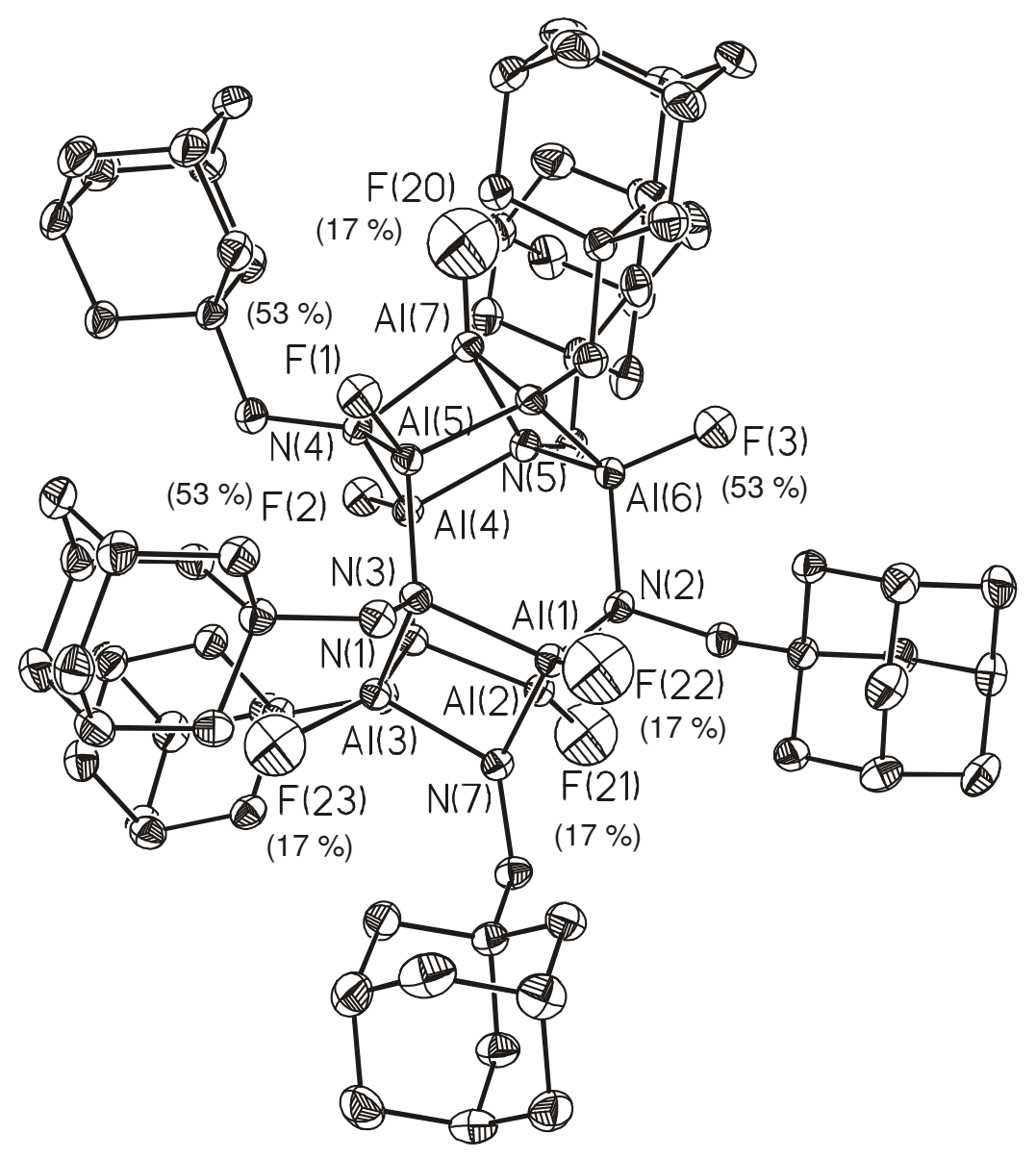

Figure 8. Molecular structure of $\mathbf{1 0}$ in the crystal (50\% probability). Hydrogen atoms and toluene molecule have been omitted for clarity.
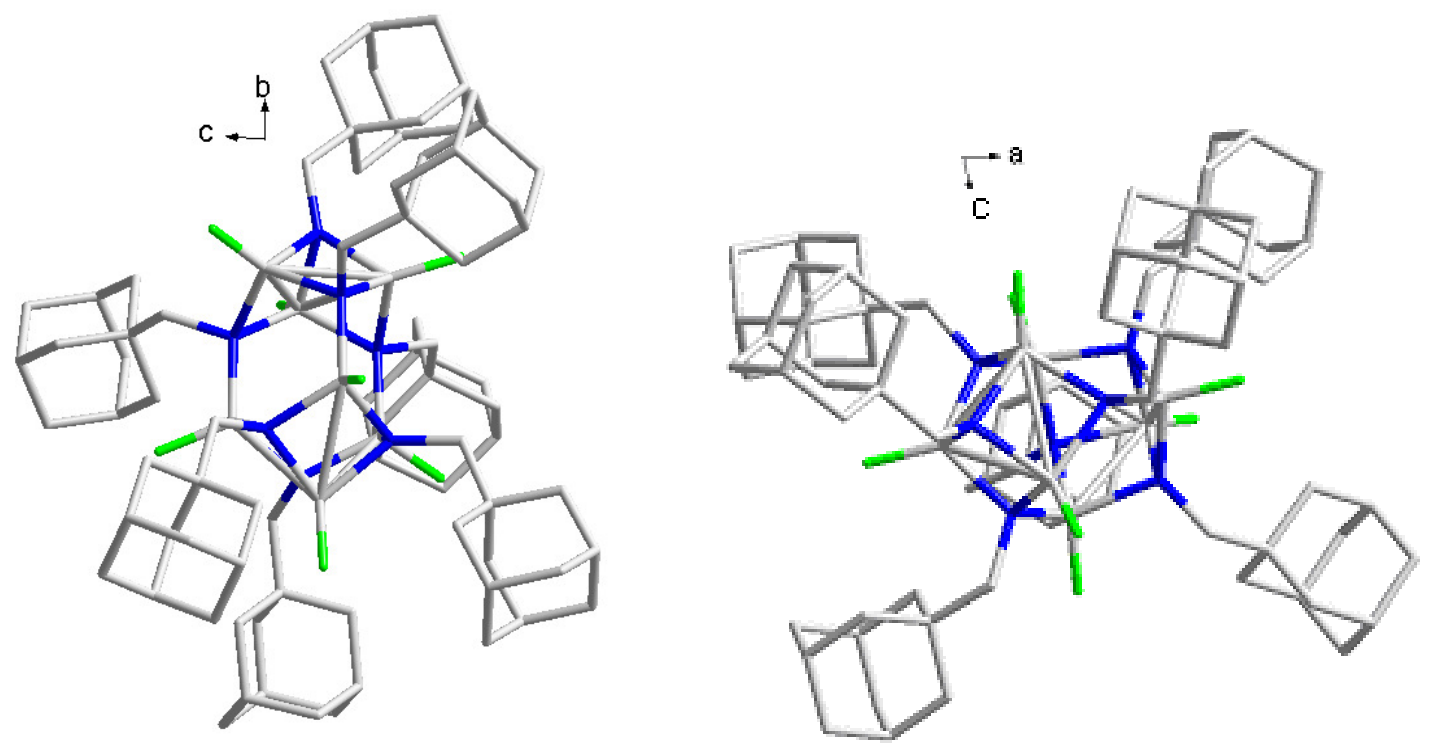


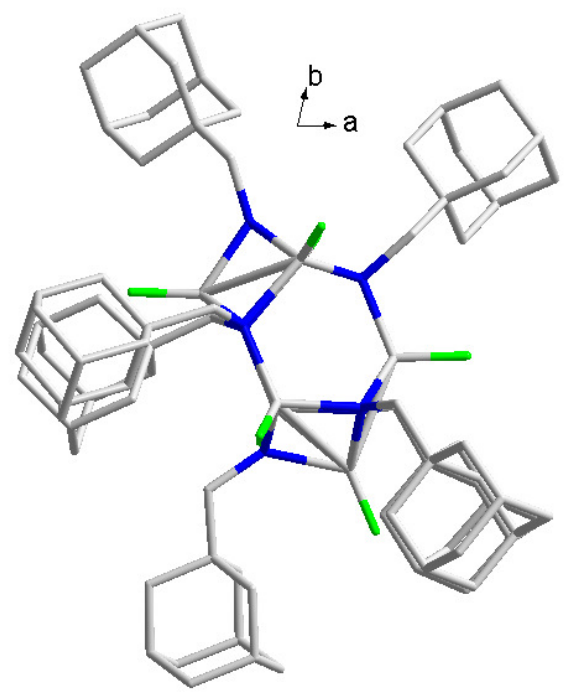

Figure 9. Core structure of $\mathbf{1 0}$ viewed along a, b, c directions.

Table 7. Selected bond lengths $(\AA)$ and angles $\left(^{\circ}\right)$ for $\mathbf{1 0}$.

\begin{tabular}{lllr}
\hline $\mathrm{Al}(1)-\mathrm{F}(22)^{*}$ & $1.506(13)$ & $\mathrm{N}(2)-\mathrm{Al}(1)-\mathrm{N}(3)$ & $109.18(7)$ \\
$\mathrm{Al}(1)-\mathrm{N}(7)$ & $1.919(2)$ & $\mathrm{F}(3)-\mathrm{Al}(6)-\mathrm{N}(2)$ & $110.84(11)$ \\
$\mathrm{Al}(1)-\mathrm{N}(2)$ & $1.942(2)$ & $\mathrm{N}(2)-\mathrm{Al}(6)-\mathrm{N}(6)$ & $114.34(8)$ \\
$\mathrm{Al}(6)-\mathrm{F}(3)$ & $1.616(3)$ & $\mathrm{N}(6)-\mathrm{Al}(6)-\mathrm{N}(5)$ & $90.96(8)$ \\
$\mathrm{Al}(6)-\mathrm{N}(2)$ & $1.883(2)$ & $\mathrm{F}(3)-\mathrm{Al}(6)-\mathrm{N}(6)$ & $113.76(11)$ \\
$\mathrm{Al}(6)-\mathrm{N}(6)$ & $1.891(2)$ & $\mathrm{F}(20)-\mathrm{Al}(7)-\mathrm{N}(6)$ & $123.9(6)$ \\
$\mathrm{Al}(7)-\mathrm{F}(20)$ & $1.475(16)$ & $\mathrm{N}(6)-\mathrm{Al}(7)-\mathrm{N}(5)$ & $89.06(7)$ \\
$\mathrm{Al}(7)-\mathrm{N}(5)$ & $1.934(2)$ & $\mathrm{Al}(4)-\mathrm{N}(1)-\mathrm{Al}(3)$ & $122.98(9)$ \\
$\mathrm{N}(1)-\mathrm{C}(15)$ & $1.539(2)$ & $\mathrm{Al}(3)-\mathrm{N}(1)-\mathrm{Al}(2)$ & $86.65(7)$ \\
$\mathrm{N}(4)-\mathrm{C}(17)$ & $1.500(3)$ & $\mathrm{C}(15)-\mathrm{N}(1)-\mathrm{Al}(4)$ & $110.04(13)$ \\
$\mathrm{N}(7)-\mathrm{C}(8)$ & $1.492(3)$ & $\mathrm{Al}(4)-\mathrm{N}(4)-\mathrm{Al}(5)$ & $112.37(9)$ \\
$\mathrm{F}(22)-\mathrm{Al}(1)-\mathrm{N}(7)$ & $127.4(5)$ & $\mathrm{Al}(4)-\mathrm{N}(4)-\mathrm{Al}(7)$ & $88.46(8)$ \\
$\mathrm{F}(22)-\mathrm{Al}(1)-\mathrm{N}(2)$ & $123.0(5)$ & $\mathrm{Al}(1)-\mathrm{N}(7)-\mathrm{Al}(3)$ & $89.23(8)$ \\
$\mathrm{N}(7)-\mathrm{Al}(1)-\mathrm{N}(2)$ & $91.54(7)$ & $\mathrm{C}(8)-\mathrm{N}(7)-\mathrm{Al}(3)$ & $128.13(14)$ \\
\hline
\end{tabular}

* the occupancy of $\mathrm{F}(1), \mathrm{F}(2)$ and $\mathrm{F}(3)$ was refined as $53 \%$, while the other four fluorine atoms $\mathrm{F}(20), \mathrm{F}(21), \mathrm{F}(22)$ and $\mathrm{F}(23)$ have each an occupancy of $17 \%$. 


\subsubsection{Preparation and $X$-ray structural analysis of 11}

Consequently, the metathesis reaction of $\mathbf{9}$ to $\mathbf{1 0}$ using $\mathrm{Me}_{3} \mathrm{SnF}$ was applied to the cluster $\left(t \mathrm{BuNCH}{ }_{2} \mathrm{AlH}\right)_{4}{ }^{20 \mathrm{a}}$ to yield the corresponding tetrafluoro compound 11. The reaction proceeds smoothly at room temperature (Scheme 7). Compound 11 crystallises in the monoclinic space

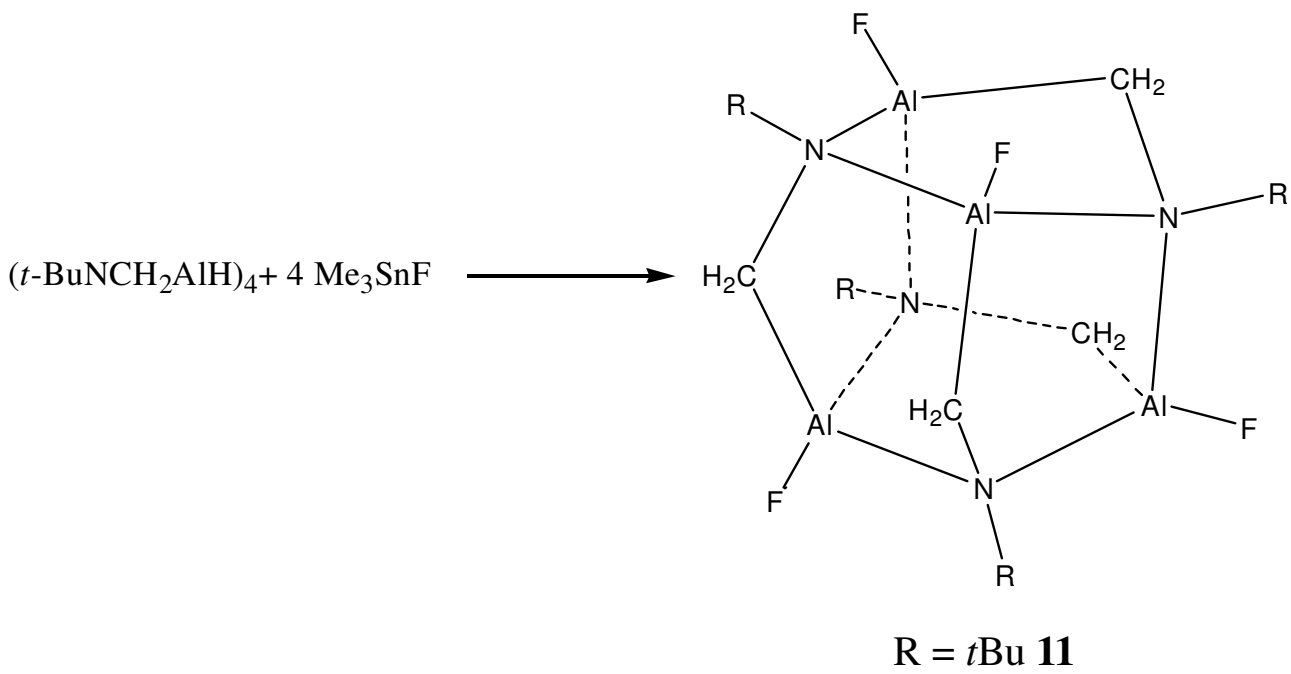

\section{Scheme 7}

group $P 2_{1} / n$. The molecular structure of $\mathbf{1 1}$ is shown in Figure 10 . The selected bond lengths and angles are listed in Table 8. The $\mathrm{Al}_{4} \mathrm{C}_{4} \mathrm{~N}_{4}$ core with four $\mathrm{F}$ atoms in place of the four $\mathrm{H}$ atoms is retained in the tetrafluoro derivative as shown in Figure 10. The four Al atoms form a distorted tetrahedron with $D_{2 d}$ symmetry (distorted by compression of the tetrahedron along one of the $C_{2}$ axis). The four shorter $\mathrm{Al}-\mathrm{Al}$ edges are each bridged by a $\mathrm{N}$ atom and every $\mathrm{N}$ atom is connected to another $\mathrm{Al}$ atom by a $\mathrm{CH}_{2}$ group. Moreover every $\mathrm{N}$ atom binds to a $t \mathrm{Bu}$ group, while each $\mathrm{Al}$ atom bears a terminal $\mathrm{F}$ atom. The terminal Al-F bond lengths (1.659 $1.666 \AA)$ are in agreement with those reported in literature $\left(\left[\left(\mathrm{Me}_{3} \mathrm{Si}_{3}\right)_{3} \mathrm{CAlF}_{2}\right]_{3}(1.657-1.681\right.$ $\AA),{ }^{54}\left(n \mathrm{Bu}_{4} \mathrm{~N}\right)_{2}\left(\mathrm{PhPO}_{3} \mathrm{AlF}_{2}\right)_{2}(1.659 \AA),\left(n \mathrm{Bu}_{4} \mathrm{~N}\right)_{2}\left(t \mathrm{BuPO}_{3} \mathrm{AlF}_{2}\right)_{2}(1.666 \AA) .{ }^{56}$ A comparison of 


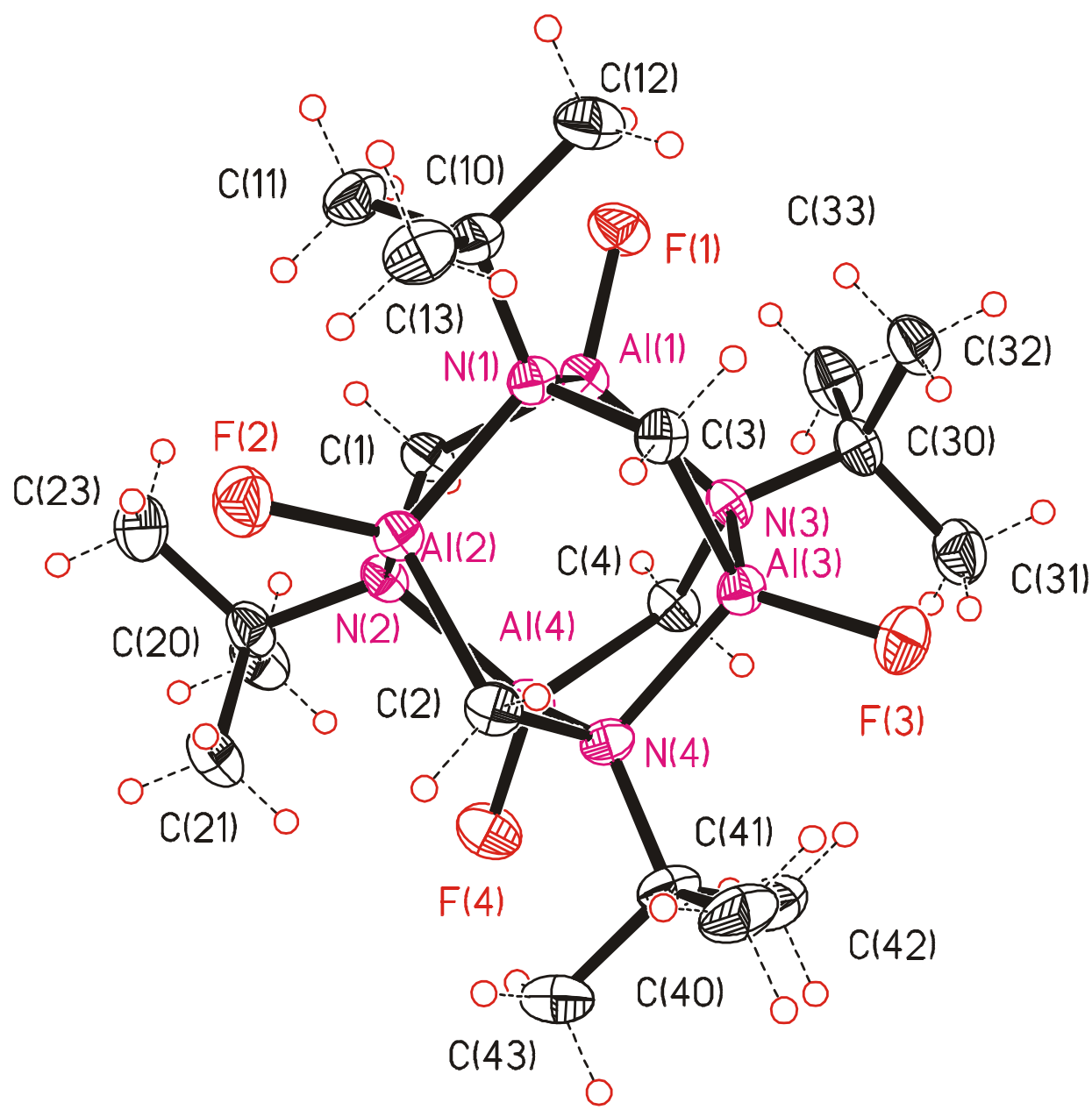

Figure 10. Molecular structure of $\mathbf{1 1}$ in the crystal (50\% probability).
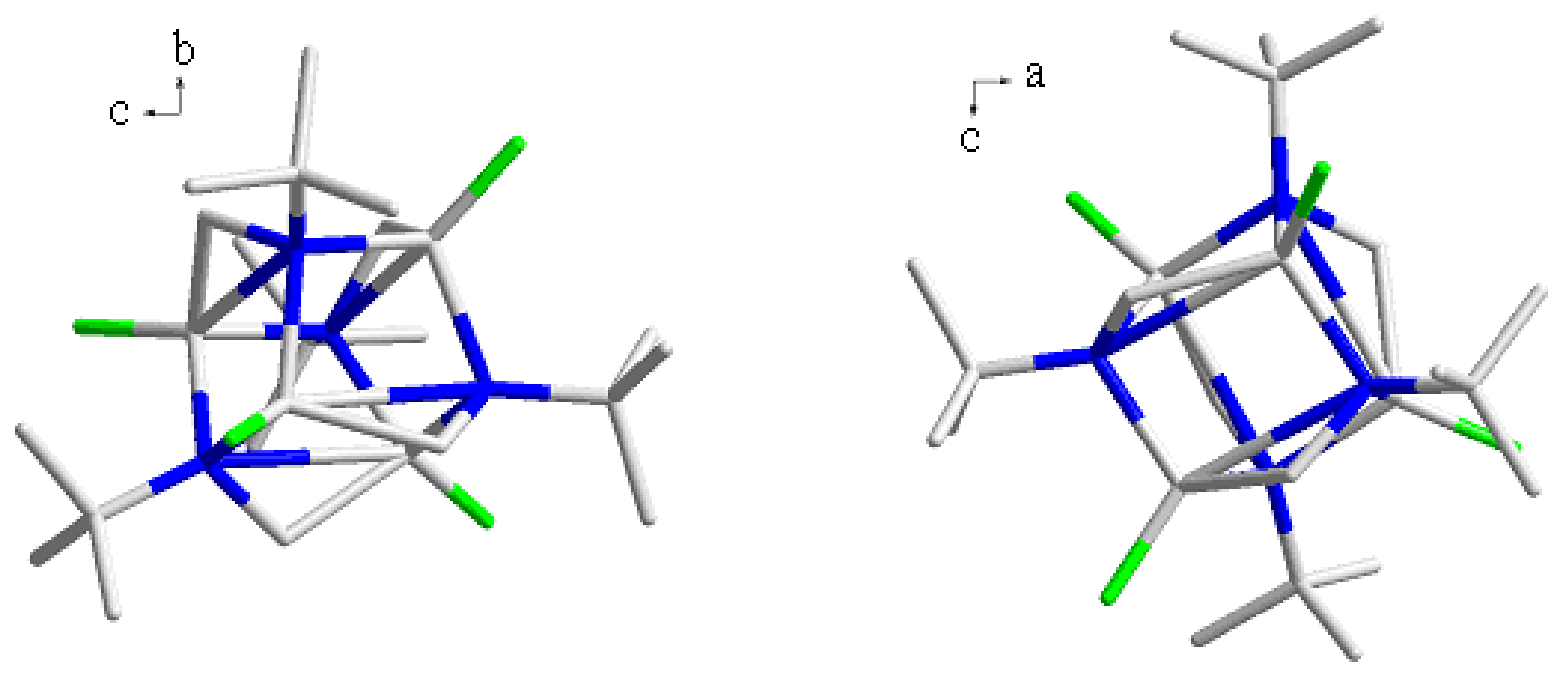


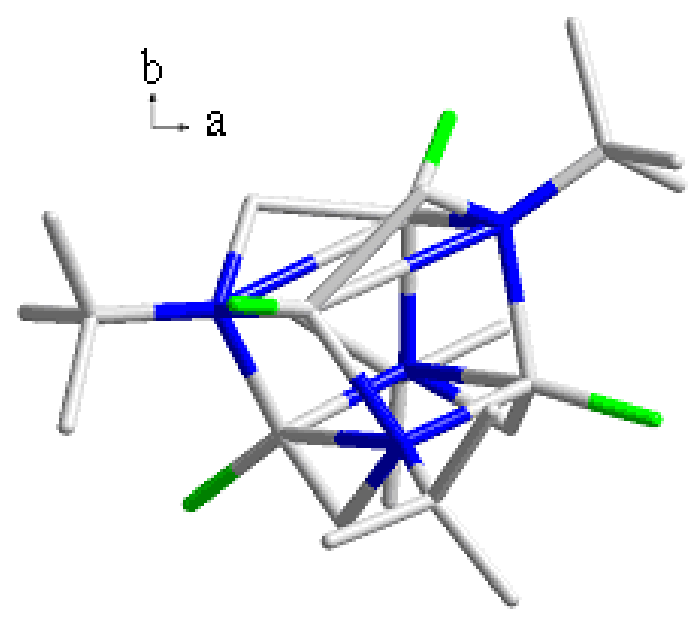

Figure 11. Core structure of $\mathbf{1 1}$ viewed along a, b, c directions.

Table 8. Selected bond lengths $(\AA)$ and angles $\left(^{\circ}\right)$ for $\mathbf{1 1}$.

\begin{tabular}{lllr}
\hline $\mathrm{Al}(1)-\mathrm{F}(1)$ & $1.6657(10)$ & $\mathrm{N}(1)-\mathrm{Al}(1)-\mathrm{N}(3)$ & $105.05(6)$ \\
$\mathrm{Al}(2)-\mathrm{F}(2)$ & $1.6586(13)$ & $\mathrm{F}(1)-\mathrm{Al}(1)-\mathrm{C}(1)$ & $114.21(6)$ \\
$\mathrm{Al}(3)-\mathrm{F}(3)$ & $1.6632(12)$ & $\mathrm{N}(1)-\mathrm{Al}(1)-\mathrm{C}(1)$ & $99.56(7)$ \\
$\mathrm{Al}(4)-\mathrm{F}(4)$ & $1.6655(11)$ & $\mathrm{N}(3)-\mathrm{Al}(1)-\mathrm{C}(1)$ & $108.21(7)$ \\
$\mathrm{Al}(1)-\mathrm{N}(1)$ & $1.952(14)$ & $\mathrm{F}(1)-\mathrm{Al}(1)-\mathrm{N}(3)$ & $114.31(6)$ \\
$\mathrm{Al}(1)-\mathrm{N}(3)$ & $1.959(16)$ & $\mathrm{C}(3)-\mathrm{N}(1)-\mathrm{C}(10)$ & $112.65(12)$ \\
$\mathrm{Al}(1)-\mathrm{C}(1)$ & $1.980(17)$ & $\mathrm{C}(3)-\mathrm{N}(1)-\mathrm{Al}(1)$ & $106.55(10)$ \\
$\mathrm{N}(1)-\mathrm{C}(3)$ & $1.526(2)$ & $\mathrm{C}(10)-\mathrm{N}(1)-\mathrm{Al}(1)$ & $115.73(10)$ \\
$\mathrm{N}(1)-\mathrm{C}(10)$ & $1.541(2)$ & $\mathrm{Al}(1)-\mathrm{N}(1)-\mathrm{Al}(2)$ & $101.56(6)$ \\
$\mathrm{F}(1)-\mathrm{Al}(1)-\mathrm{N}(1)$ & $114.14(6)$ & $\mathrm{N}(2)-\mathrm{C}(1)-\mathrm{Al}(1)$ & $109.06(10)$ \\
\hline
\end{tabular}

the ${ }^{19} \mathrm{~F}$ NMR shifts of compounds having only terminal Al-F bonds is given in Table 9. The chemical shifts for the ${ }^{19} \mathrm{~F}$ NMR of $\mathbf{1 0}(-163.9,-162.8,-162.2 \mathrm{ppm})$ and $\mathbf{1 1}(-155.7 \mathrm{ppm})$ are in the range of compounds with terminal fluorine atoms which values range from -145.9 to $-180.0 \mathrm{ppm}$. 
Table 9. ${ }^{19}$ F NMR spectra of terminal Al-F bonds

\begin{tabular}{|c|c|}
\hline Compound & ${ }^{19} \mathrm{~F}$ \\
\hline$\left(\mathrm{Me}_{3} \mathrm{Si}\right)_{3} \mathrm{CAlF}_{2} \cdot \mathrm{THF}^{52}$ & -159.2 \\
\hline$\left(2,6-i \mathrm{Pr}_{2} \mathrm{C}_{6} \mathrm{H}_{3}\right) \mathrm{N}\left(\mathrm{SiMe}_{3}\right) \mathrm{AlF}_{2} \cdot \mathrm{THF}^{53 \mathrm{a}}$ & -178.1 \\
\hline$\left(2,6-\mathrm{Me}_{2} \mathrm{C}_{6} \mathrm{H}_{3}\right) \mathrm{N}\left\{\mathrm{Si}(t \mathrm{Bu}) \mathrm{Me}_{2}\right\} \mathrm{AlF}_{2} \cdot \mathrm{THF}^{53 \mathrm{a}}$ & -175.0 \\
\hline$\left(n \mathrm{Bu}_{4} \mathrm{~N}\right)_{2}\left(\mathrm{PhPO}_{3} \mathrm{AlF}_{2}\right)_{2}^{58}$ & -180.0 \\
\hline$\left(n \mathrm{Bu}_{4} \mathrm{~N}\right)_{2}\left(t \mathrm{BuPO}_{3} \mathrm{AlF}_{2}\right)_{2}{ }^{58}$ & -179.5 \\
\hline$\left(n \mathrm{Bu}_{4} \mathrm{~N}\right)\left(\mathrm{RMeAlF}_{2}\right)(\mathrm{R}=\mathrm{Me})^{59}$ & -154.8 \\
\hline$\left(n \mathrm{Bu}_{4} \mathrm{~N}\right)\left(\mathrm{RMeAlF}_{2}\right)\left(\mathrm{R}=\left(\mathrm{Me}_{3} \mathrm{Si}\right)_{3} \mathrm{C}\right)^{59}$ & -145.9 \\
\hline$\left(\mathrm{Me}_{4} \mathrm{~N}\right)\left(i \mathrm{Bu}_{2} \mathrm{AlF}_{2}\right)^{60}$ & -149.4 \\
\hline$\left(\mathrm{Ph}_{4} \mathrm{P}\right)\left(i \mathrm{Bu}_{2} \mathrm{AlF}_{2}\right)^{60}$ & -151.7 \\
\hline$\left(1-\mathrm{AdCH}_{2} \mathrm{NAl}\right)_{7} \mathrm{~F}_{2.26} \mathrm{H}_{4.74}{ }^{*}$ & $-163.9,-162.8,-162.2$ \\
\hline$\left(t \mathrm{BuNCH}_{2} \mathrm{AlF}\right)_{4}{ }^{*}$ & -155.7 \\
\hline
\end{tabular}

* this work

\subsection{Reactions of monomeric organoaluminum(I) compounds}

$\mathrm{LAl}^{\mathrm{I}}\left(\right.$ 12) $\left(\mathrm{L}=\mathrm{HC}(\mathrm{CMeNAr})_{2}, \mathrm{Ar}=2,6-i \mathrm{Pr}_{2} \mathrm{C}_{6} \mathrm{H}_{3}\right)^{31}$ with its non-bonding lone pair of electrons at aluminum indicates a singlet carbene-like character. It could be used in carbene type reactions, as a Lewis base, and as a reducing reagent, which may show remarkable and unprecedented chemical reactions. However, the yield of $\mathbf{1 2}$ is low (21\%), in order to improve the yield we tried a more bulky $\beta$-diketiminato ligand $\left[\mathrm{HC}(\mathrm{CPhNAr})_{2}\right] \mathrm{H}^{66 \mathrm{a}}$ within the backbone of $\mathrm{Ph}$ substituents in place of Me groups for the preparation of $\mathrm{Al}(\mathrm{I})$ compound.

\subsubsection{Preparation and structural analysis of $\left[\mathrm{HC}(\mathrm{CPhNAr})_{2}\right] \mathrm{AlMe}_{2}\left(\mathrm{Ar}=2,6-i \mathrm{Pr}_{2} \mathrm{C}_{6} \mathrm{H}_{3}\right)$}


Since the disclosure by K. Ziegler et al. of the "aufbau" reaction, alkylaluminum compounds have been known as olefin oligomerisation catalysts, because of the displacement reaction competing with a "smooth stepwise addition of ethylene". ${ }^{66 b}$ In 1992 H. Martin and H. Bretinger demonstrated that the growth reaction of ethylene at bis(dichloroaluminum)ethane and trialkylaluminum produces with low activity polyethylene of high molecular weight and thermoplastic character. ${ }^{66 \mathrm{c}}$ More recently, A. Sen et al. reported that simple alkylaluminum compounds, after reaction with the activators commonly used in the homogeneous olefin polymerisation catalysis $\left\{\right.$ i.e. $\left.\mathrm{B}\left(\mathrm{C}_{6} \mathrm{~F}_{5}\right)_{3},\left[\left(\mathrm{C}_{6} \mathrm{H}_{5}\right)_{3} \mathrm{C}\right]\left[\mathrm{B}\left(\mathrm{C}_{6} \mathrm{~F}_{5}\right)_{4}\right]\right\}$, are able to catalyse the polymerisation of ethylene and propene, although with low activity. ${ }^{66 \mathrm{~d}}$

Compound 13 was synthesised from the reaction of $\mathrm{AlMe}_{3}$ with ligand $\left[\mathrm{HC}(\mathrm{CPhNAr})_{2}\right] \mathrm{H}$ in refluxing toluene in a 1:1 ratio. When the reaction was carried out at $0{ }^{\circ} \mathrm{C}$ or room temperature it did not proceed completely, and the proton of the $\mathrm{NH}$ group of the ligand was observed in the ${ }^{1} \mathrm{H}$ NMR spectrum. Compound $\mathbf{1 3}$ was characterised by NMR and elemental analysis as well as by X-ray structural analysis. The ${ }^{1} \mathrm{H}$ NMR spectrum exhibits the expected set of ligand proton signals and a high-field singlet for the Al-Me protons $(\delta-0.76 \mathrm{ppm}, \mathrm{s})$. Treatment of 13 with an equivalent or excess of $\mathrm{I}_{2}$ at room temperature or heating did not lead to the expected product $\left[\mathrm{HC}(\mathrm{CPhNAr})_{2}\right] \mathrm{AlI}_{2}$. The $\left[\mathrm{HC}(\mathrm{CMeNAr})_{2}\right] \mathrm{H}$ ligand is easier prepared and possesses better solubility, therefore we selected $\mathbf{1 2}$ as the starting material for the following reactions.

The X-ray crystal structure of $\mathbf{1 3}$ is given in Figure 12. Compound $\mathbf{1 3}$ crystallises in the monoclinic space group $P 2 / c$. The symmetry of $\mathbf{1 3}$ is $C_{s}$. Selected bond lengths and angles are given in Table 10. The Al-N distances (1.933(4) and 1.932(4) $\AA$ ) are comparable with those of 
$\left[\mathrm{HC}(\mathrm{CMeNAr})_{2}\right] \mathrm{AlMe}_{2}(1.922(2)$ and $1.935(2) \AA) .{ }^{43}$ The Al-Me distances (1.961(7) and $1.982(7) \AA$ ) are slightly longer than those of $\left[\mathrm{HC}(\mathrm{CMeNAr})_{2}\right] \mathrm{AlMe}_{2}(1.958(3)$ and $1.970(3)$ $\AA) .{ }^{43}$ The bond angles of N-Al-N $\left(95.99(19)^{\circ}\right)$ and C-Al-C $\left(115.7(3)^{\circ}\right)$ are similar to those of $\left[\mathrm{HC}(\mathrm{CMeNAr})_{2}\right] \mathrm{AlMe}_{2}\left(96.18(9)\right.$ and $\left.117.40(13)^{\mathrm{o}}\right){ }^{43}$ Thus we conclude that the substituents on the backbone at the $\mathrm{C}$ atoms do not affect much the bond lengths and bond angles. The six-membered ring of $\mathrm{L}$ is not in one plane any more: the dihedral angle of $\mathrm{Al}(1)-$ $\mathrm{N}(2)-\mathrm{C}(5)-\mathrm{C}(4)$ is $23.28(64)^{\circ}$. This distortion may originate from significant steric repulsion between two adjacent phenyl rings. The shortest $\mathrm{H} \cdots \mathrm{H}$ distance between two phenyl rings is only $2.192(15) \AA$, which is close to the sum of their van der Waals radii. If the six-membered ring is not distorted this distance will be even shorter, and gives significant steric repulsion.

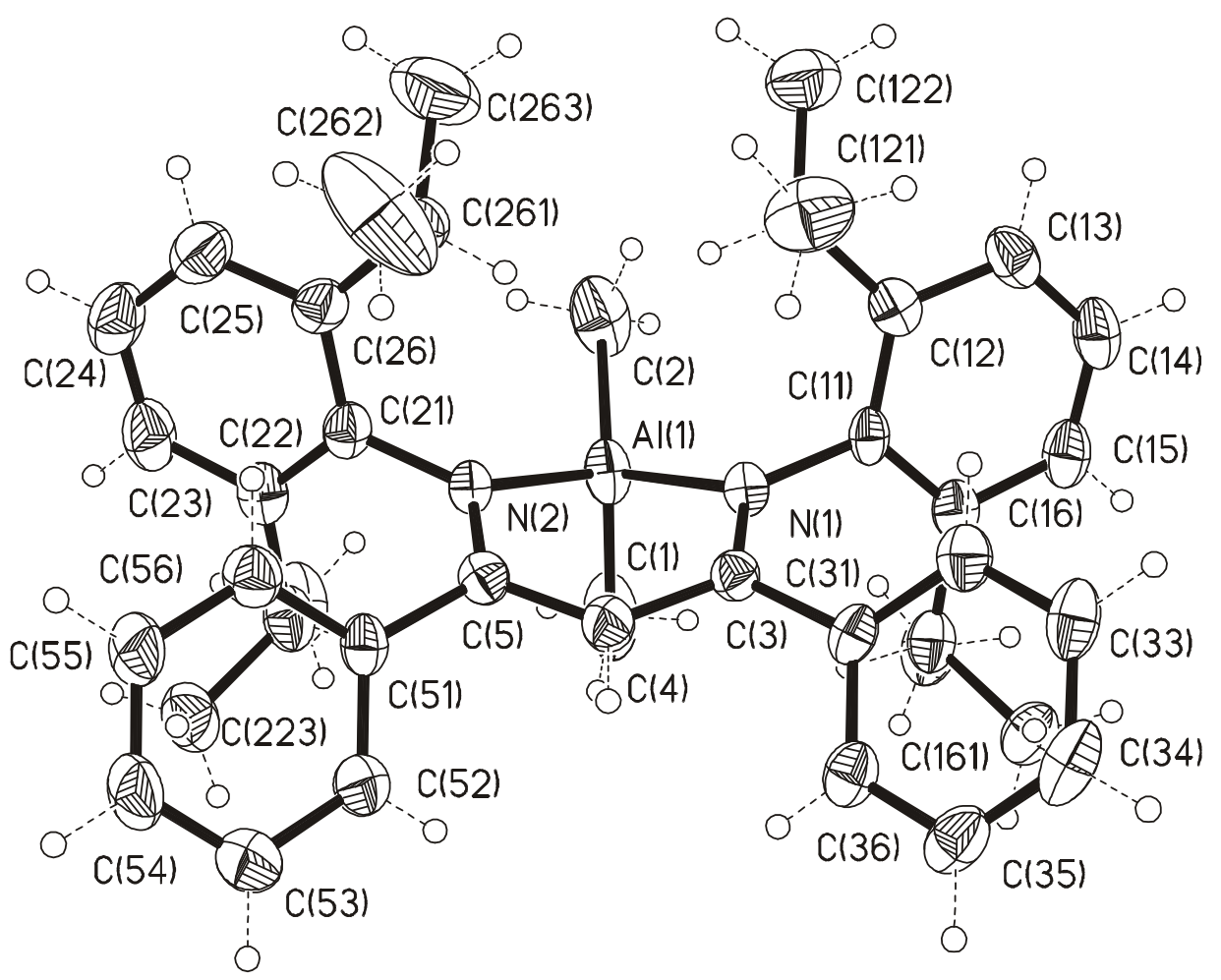

Figure 12. Molecular structure of $\mathbf{1 3}$ in the crystal. 
Table 10. Selected bond lengths $(\AA)$ and angles $\left(^{\circ}\right)$ for 13.

\begin{tabular}{lcll}
\hline $\mathrm{Al}(1)-\mathrm{N}(2)$ & $1.933(4)$ & $\mathrm{N}(1)-\mathrm{Al}(1)-\mathrm{C}(2)$ & $115.3(3)$ \\
$\mathrm{Al}(1)-\mathrm{N}(1)$ & $1.932(4)$ & $\mathrm{N}(2)-\mathrm{Al}(1)-\mathrm{C}(1)$ & $109.6(3)$ \\
$\mathrm{Al}(1)-\mathrm{C}(2)$ & $1.961(7)$ & $\mathrm{N}(1)-\mathrm{Al}(1)-\mathrm{C}(1)$ & $107.2(3)$ \\
$\mathrm{Al}(1)-\mathrm{C}(1)$ & $1.982(7)$ & $\mathrm{C}(2)-\mathrm{Al}(1)-\mathrm{C}(1)$ & $115.7(3)$ \\
$\mathrm{N}(2)-\mathrm{C}(5)$ & $1.346(7)$ & $\mathrm{C}(3)-\mathrm{N}(1)-\mathrm{Al}(1)$ & $118.0(4)$ \\
$\mathrm{C}(4)-\mathrm{C}(5)$ & $1.390(8)$ & $\mathrm{C}(5)-\mathrm{N}(2)-\mathrm{Al}(1)$ & $116.5(3)$ \\
$\mathrm{N}(1)-\mathrm{C}(3)$ & $1.338(6)$ & $\mathrm{N}(2)-\mathrm{C}(5)-\mathrm{C}(4)$ & $122.4(5)$ \\
$\mathrm{C}(3)-\mathrm{C}(4)$ & $1.421(7)$ & $\mathrm{N}(1)-\mathrm{C}(3)-\mathrm{C}(4)$ & $121.3(5)$ \\
$\mathrm{N}(2)-\mathrm{Al}(1)-\mathrm{N}(1)$ & $95.99(19)$ & $\mathrm{C}(5)-\mathrm{C}(4)-\mathrm{C}(3)$ & $129.7(5)$ \\
$\mathrm{N}(2)-\mathrm{Al}(1)-\mathrm{C}(2)$ & $111.3(3)$ & & \\
\hline
\end{tabular}

\subsubsection{Preparation of $\left[\mathrm{HC}(\mathrm{CMeNAr})_{2}\right]_{2} \mathrm{Al}_{2} \mathrm{P}_{4}\left(\mathrm{Ar}=2,6-i \mathrm{Pr}_{2} \mathrm{C}_{6} \mathrm{H}_{3}\right)(14)$ with a formal $\mathrm{P}_{4}{ }^{4-}$} charged species

The chemistry of white phosphorus has gained great interest over the past decades due to its tetrahedral structure and variable bonding modes. Organophosphorus compounds are used as reagents ${ }^{67}$ and ligands for a cornucopia of complexes in catalytic processes. ${ }^{68}$ Reactions of transition-metal complexes with white phosphorus have been extensively studied and have resulted in a large variety of $\mathrm{P}_{\mathrm{x}}$ complexes with unpredicted structures. ${ }^{69}$ Among them, only one compound $\left[\mathrm{Cp}_{2} *(\mathrm{CO})_{2} \mathrm{Co}_{2} \mathrm{P}_{4}\right]^{70}$ with a $\mathrm{P}_{4}{ }^{4-}$ species has been reported. Reactions of the $\mathrm{P}_{4}$ molecule with main group metal complexes were limited to a few examples, [(AlCp* $\left.)_{6} \mathrm{P}_{4}\right]$ $\left(\mathrm{Cp}^{*}=\mathrm{C}_{5} \mathrm{Me}_{5}\right),{ }^{28}\left[(\mathrm{GaR})_{3} \mathrm{P}_{4}\right]\left(\mathrm{R}=\left(\mathrm{SiMe}_{3}\right)_{3} \mathrm{C}\right),{ }^{71 \mathrm{a}}$ and $\left[\mathrm{Ga}_{2} \mathrm{P}_{4} t \mathrm{Bu}_{6}\right] \cdot{ }^{71 \mathrm{~b}}$ Compounds containing the heavy elements of group 13 and 15 were used as models in bonding theory ${ }^{72}$ and as precursor for semi conducting materials. ${ }^{73}$ Herein we report the reaction of $\mathbf{1 2}$ with white 
phosphorus to yield the first main group complex of composition $\left[(\mathrm{LAl})_{2} \mathrm{P}_{4}\right](\mathbf{1 4})$ containing the $\mathrm{P}_{4}{ }^{4-}$ species.

Treatment of two equivalents of $\mathbf{1 2}$ with white phosphorus at room temperature leads to 14 in good yield (Scheme 8). In contrast, the reaction of the tetrahedral aluminum(I) compound $\left(\mathrm{AlCp}^{*}\right)_{4}\left(\mathrm{Cp}^{*}=\mathrm{C}_{5} \mathrm{Me}_{5}\right)^{24}$ with white phosphorus gave the electron deficient<smiles></smiles>

12

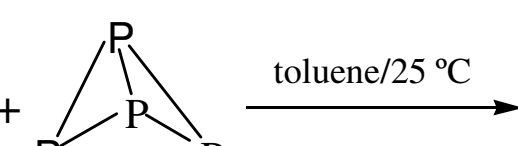<smiles></smiles>

Ar

14

\section{Scheme 8}

cage compound $\left(\mathrm{AlCp}^{*}\right)_{6} \mathrm{P}_{4},{ }^{28}$ which consists of two face-sharing heterocubanes with two opposite corners unoccupied, as well as four $\mathrm{P}$ atoms from the complete cleavage of the $\mathrm{P}_{4}$ molecule. Therefore we reacted $\mathbf{1 2}$ and $\mathrm{P}_{4}$ in a 4:1 ratio to explore the possibility of complete cleavage of all P-P bonds, however we obtained 14 and unreacted 12 based on ${ }^{1} \mathrm{H}$ and ${ }^{31} \mathrm{P}$ NMR investigations. Obviously the bulky ligand L prevents the arrangement of a larger number of LAl moieties around the P atoms. When the reaction was carried out in a ratio of 1:1 between 12 and $\mathrm{P}_{4}, \mathbf{1 4}$ and unreacted $\mathrm{P}_{4}$ together with some byproducts were obtained due to the results of ${ }^{1} \mathrm{H}$ and ${ }^{31} \mathrm{P}$ NMR investigations. Compound $\mathbf{1 4}$ is air sensitive and decomposes at $145^{\circ} \mathrm{C} . \mathbf{1 4}$ is sparingly soluble in pentane and hexane, but readily soluble in benzene, toluene and diethylether. In $\mathrm{CDCl}_{3}$ we observed the decomposition of 14. 
Compound 14 was characterised by ${ }^{1} \mathrm{H},{ }^{13} \mathrm{C}$ and ${ }^{31} \mathrm{P}$ NMR spectroscopy using benzene- $\mathrm{d}_{6}$ as the solvent, by EI mass spectrometry and elemental analysis. The EI mass spectrum shows the molecular ion of $\mathbf{1 4}$. The ${ }^{31} \mathrm{P}$ NMR spectrum of $\mathbf{1 4}(78.6 \mathrm{ppm})$ exhibits a strong chemical shift difference compared to that of the free $\mathrm{P}_{4}$ molecule $(-519 \mathrm{ppm})$. No resonances were observed in $\mathrm{C}_{6} \mathrm{D}_{6}$ solution for the ${ }^{27} \mathrm{Al}$ NMR of $\mathbf{1 4}$, thus the measurement in solid state was carried out and signals in a range of $50-120 \mathrm{ppm}$ were found which are comparable to those for four coordinated $\mathrm{Al}(\mathrm{III})$ compounds, but much different from the resonance for $\mathrm{LAl}^{\mathrm{I}}(\mathbf{1 2})$ $\left(590 \pm 40 \mathrm{ppm}, v_{1 / 2}=30000 \mathrm{~Hz}\right) .{ }^{74}$ In the ${ }^{1} \mathrm{H}$ NMR pattern of $\mathbf{1 4}$, only one set of resonances for the L ligand was detected indicating that the two L ligands are in the same chemical environment.

\subsubsection{Molecular structure of 14}

The X-ray single-crystal structural analysis confirms the composition of $\mathbf{1 4}$ (Figure 13). 14 crystallises in the orthorhombic space group $P 2{ }_{1} 2_{1} 2_{1}$ with one molecule of pentane. As shown in Figure 13, compound $\mathbf{1 4}$ contains an $\mathrm{Al}_{2} \mathrm{P}_{4}$ core, and the four-membered $\mathrm{P}_{4}$ ring is attached to two LAl moieties. Selected bond lengths and angles are listed in Table 11. The Al-P bond length (av. $2.37 \AA$ ) of $\mathbf{1 4}$ is in the range of those in $\left(\mathrm{AlCp}^{*}\right)_{6} \mathrm{P}_{4}(2.31$ to $2.42 \AA){ }^{28}$ The P-P bond length (av. $2.29 \AA$ ) is slightly longer than that in $\mathrm{Cp}_{2} *(\mathrm{CO})_{2} \mathrm{Co}_{2} \mathrm{P}_{4}$ (av. 2.23 $\AA) .{ }^{70}$ The distances between $\mathrm{P}(1)-\mathrm{P}(3)$ and $\mathrm{P}(2)-\mathrm{P}(4)$ in $14(3.049(2)$ and 3.063(2) $\AA$ ) are distinctly longer than those in $\mathrm{Cp}_{2} *(\mathrm{CO}){ }_{2} \mathrm{Co}_{2} \mathrm{P}_{4}(2.560(2), 2.597(2) \AA),{ }^{70}$ which shows the 


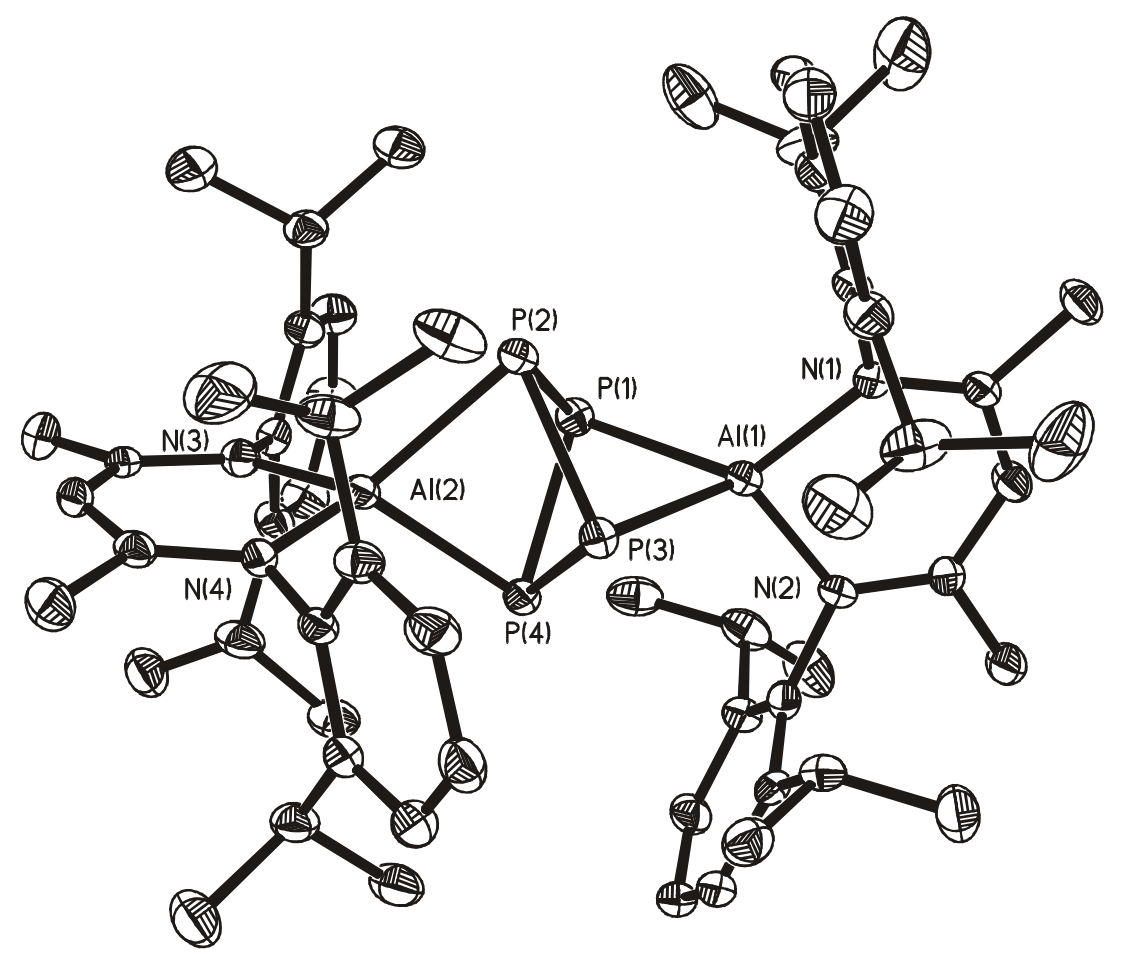

Figure 13. The crystal structure of 14. The hydrogen atoms of the $\mathrm{C}-\mathrm{H}$ bonds are omitted for clarity.

cleavage of two P-P bonds within the $\mathrm{P}_{4}$ molecule. The Al-N bond lengths (av. $1.90 \AA$ ) are in the range of other aluminum derivatives bearing the ligand L. ${ }^{19 a}$ The average P-Al-P bond angle is $80.27^{\circ}$. The symmetry of the compound is roughly $D_{2 d}$, which means the two L ligand planes are vertical.

\subsubsection{Theoretical calculations for 14}

DFT calculations with RI-BP86/TZVP within TURBOMOLE ${ }^{44,45}$ were carried out to investigate the electronic structure of $\mathbf{1 4}$. The calculated Mulliken charges on the $\mathrm{P}$ atoms $(-0.22)$ show a significant charge transfer from the $\mathrm{Al}$ atoms to the $\mathrm{P}_{4}$ unit, which indicates the 
formation of ionic Al-P bonds. The bond order (shared electrons between two P atoms) of P-P bonds (0.01) supports the complete cleavage of the $\mathrm{P}(1)-\mathrm{P}(3)$ and $\mathrm{P}(2)-\mathrm{P}(4)$ bonds.

Table 11. Selected bond lengths $(\AA)$ and angles $\left(^{\circ}\right)$ for $\mathbf{1 4}$.

\begin{tabular}{llll}
\hline $\mathrm{Al}(1)-\mathrm{P}(1)$ & $2.377(2)$ & $\mathrm{P}(3)-\mathrm{Al}(1)-\mathrm{P}(1)$ & $80.16(7)$ \\
$\mathrm{Al}(1)-\mathrm{P}(3)$ & $2.359(2)$ & $\mathrm{P}(2)-\mathrm{P}(1)-\mathrm{P}(4)$ & $83.98(7)$ \\
$\mathrm{P}(1)-\mathrm{P}(2)$ & $2.287(2)$ & $\mathrm{P}(3)-\mathrm{P}(2)-\mathrm{P}(1)$ & $83.69(8)$ \\
$\mathrm{P}(1)-\mathrm{P}(4)$ & $2.292(2)$ & $\mathrm{P}(2)-\mathrm{P}(3)-\mathrm{P}(4)$ & $83.96(8)$ \\
$\mathrm{P}(2)-\mathrm{P}(3)$ & $2.284(2)$ & $\mathrm{P}(1)-\mathrm{P}(4)-\mathrm{P}(3)$ & $83.34(8)$ \\
$\mathrm{P}(3)-\mathrm{P}(4)$ & $2.295(2)$ & $\mathrm{P}(2)-\mathrm{P}(1)-\mathrm{Al}(1)$ & $81.64(8)$ \\
$\mathrm{P}(1) \cdots \mathrm{P}(3)$ & $3.049(2)$ & $\mathrm{P}(4)-\mathrm{P}(1)-\mathrm{Al}(1)$ & $77.60(7)$ \\
$\mathrm{P}(2) \cdots \mathrm{P}(4)$ & $3.063(2)$ & $\mathrm{P}(2)-\mathrm{P}(3)-\mathrm{Al}(1)$ & $82.07(8)$ \\
$\mathrm{Al}(1)-\mathrm{N}(1)$ & $1.897(5)$ & $\mathrm{P}(4)-\mathrm{P}(3)-\mathrm{Al}(1)$ & $77.91(7)$ \\
$\mathrm{Al}(1)-\mathrm{N}(2)$ & $1.912(5)$ & $\mathrm{N}(1)-\mathrm{Al}(1)-\mathrm{N}(2)$ & $95.5(2)$ \\
$\mathrm{N}(1)-\mathrm{C}(2)$ & $1.355(7)$ & $\mathrm{N}(1)-\mathrm{Al}(1)-\mathrm{P}(3)$ & $118.18(16)$ \\
$\mathrm{C}(2)-\mathrm{C}(3)$ & $1.411(8)$ & $\mathrm{C}(2)-\mathrm{N}(1)-\mathrm{Al}(1)$ & $124.1(4)$ \\
$\mathrm{C}(3)-\mathrm{C}(4)$ & $1.383(8)$ & $\mathrm{N}(1)-\mathrm{C}(2)-\mathrm{C}(3)$ & $122.7(5)$ \\
$\mathrm{N}(2)-\mathrm{C}(4)$ & $1.339(7)$ & $\mathrm{C}(4)-\mathrm{C}(3)-\mathrm{C}(2)$ & $127.5(5)$ \\
\hline
\end{tabular}

The calculated binding energy $\left[\mathrm{E}\left((\mathrm{LM})_{2}-\mathrm{P}_{4}\right)-2 * \mathrm{E}(\mathrm{L}-\mathrm{M})-\mathrm{E}\left(\mathrm{P}_{4}\right) / 2.0\right](36.4 \mathrm{kcal} / \mathrm{mol})$ shows the strong interaction between the $\mathrm{P}_{4}$ unit and the $\mathrm{Al}$ atoms.

In the uncoordinated $\mathrm{P}_{4}$ molecule the average P-P distance lies around $2.21 \AA$. Herein we use $\mathrm{PH}_{2}-\mathrm{PH}_{2}$ as an example to study how much the P-P bond loses energy during its extension. ${ }^{75}$ The energy curve of $\mathrm{PH}_{2}-\mathrm{PH}_{2}$ for the $\mathrm{P}-\mathrm{P}$ distance (1.7 to $3.6 \AA$ ) is given in Figure 14. It shows that near the minimum the curve is quite flat. At $\mathrm{r}(\mathrm{P}-\mathrm{P})>3.0 \AA$, most of the bond energy is lost and the bond order is about zero. 


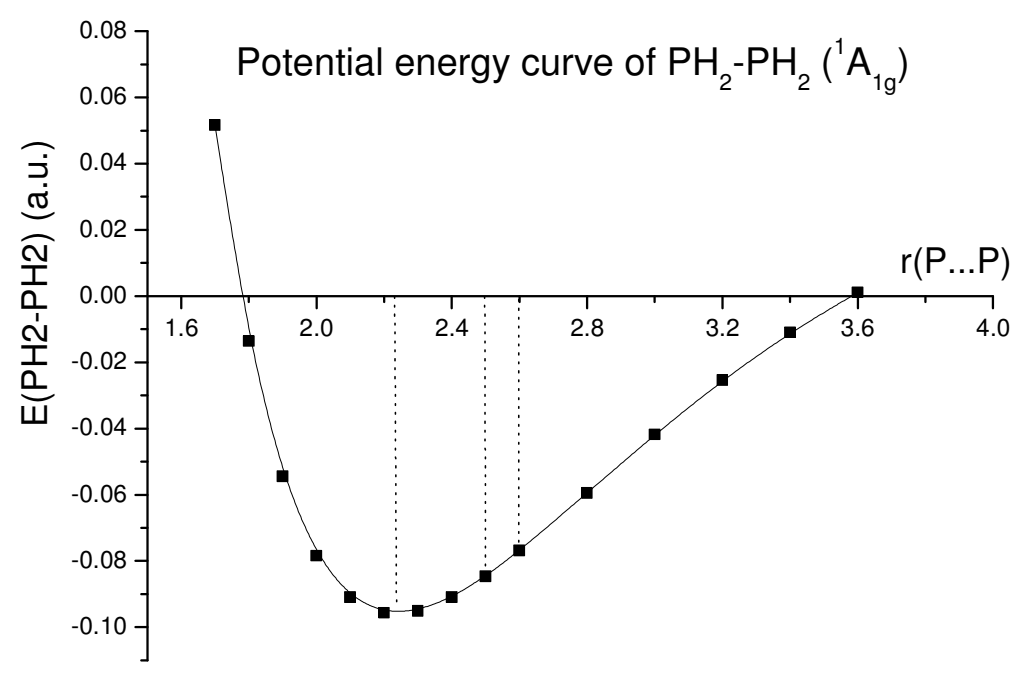

Figure 14. Potential energy curve of $\mathrm{PH}_{2}-\mathrm{PH}_{2}\left(0\right.$ means no binding energy for two $\mathrm{PH}_{2}$ radicals).

In conclusion, both the charge calculation and the P-P bond analysis support the ionic Al- $\mathrm{P}_{4}$ bond for $\mathbf{1 4}$. Therefore in $\mathbf{1 4}$ the $\mathrm{P}_{4}$ moiety is carrying formally four negative charges.

In summary, the reaction of $\mathrm{LAl}^{\mathrm{I}}(\mathbf{1 2})$ with white phosphorus yields the first main group complex $(\mathrm{LAl})_{2} \mathrm{P}_{4}(\mathbf{1 4})$ containing the $\mathrm{P}_{4}^{4-}$ species, in which two $\mathrm{P}-\mathrm{P}$ edges of the $\mathrm{P}_{4}$ tetrahedron are opened and each is bridged by a LAl moiety.

\subsubsection{Preparation of a bimetallic derivative of the sulphur crown $\mathrm{S}_{8}: \operatorname{LAl}\left(\mu-\mathrm{S}_{3}\right)_{2} \mathrm{AlL}(\mathrm{L}=$} $\left.\mathrm{HC}(\mathrm{CMeNAr})_{2}, \mathrm{Ar}=2,6-i \mathrm{Pr}_{2} \mathrm{C}_{6} \mathrm{H}_{3}\right)(15)$

Metal polysulfides, synthesized by a variety of methods using various reagents as sulphur source, such as $\mathrm{S}_{8}, \mathrm{M}_{2} \mathrm{~S}_{\mathrm{n}}(\mathrm{M}=$ alkali metal $), \mathrm{P}_{4} \mathrm{~S}_{10}, \mathrm{H}_{2} \mathrm{~S}$ and organic polysulfanes, have attracted much attention not only regarding their structure and reactivity but also due to their potential uses. ${ }^{76}$ Metal polysulfide complexes ${ }^{76 \mathrm{~b}}$ may be viewed as derivatives of the $\mathrm{S}_{\mathrm{x}}{ }^{2-}$ 
$(\mathrm{x} \geq 2)$ ion. Transition metal polysulfides have attracted interest as catalysts and intermediates in enzymatic processes and in catalytic reactions of industrial importance such as the hydrodesulphurisation (HDS) of fossil fuels. ${ }^{77}$ Furthermore, the metal polysulfides can be used as precursor for metal-sulphur clusters. In contrast, such complexes containing heavier main group elements such as Group 13, 14, and 15 metals have been much less explored. ${ }^{76 a, 76 d}$ The examples are: $\operatorname{Tbt}(\mathrm{R}) \mathrm{ME}_{4}(\mathrm{M}=\mathrm{Si}, \mathrm{Ge}, \mathrm{Sn}, \mathrm{Pb} ; \mathrm{E}=\mathrm{S}$, Se; Tbt = 2,4,6-tris[bis(trimethylsilyl)methyl]phenyl; $\mathrm{R}=$ aryl group). ${ }^{76 \mathrm{~d}}$ Among the numerous investigations of the metal polysulfides, complexes with the $\left(\mu-S_{3}\right)$ chain were rarely reported. The most common examples are those of transition metal complexes $\left[\left(\eta^{5}-\mathrm{RC}_{5} \mathrm{H}_{4}\right)_{2} \mathrm{Ti}\left(\mu-\mathrm{S}_{3}\right)\right]_{2}$ $(\mathrm{R}=\mathrm{H}, \mathrm{Me})^{78}$ and $\left[\left(\eta^{5}-\mathrm{MeC}_{5} \mathrm{H}_{4}\right) \mathrm{Ru}\left(\mathrm{PPh}_{3}\right)\left(\mu-\mathrm{S}_{3}\right)\right]_{2}{ }^{79}$ which were obtained by treatment of $\left(\eta^{5}-\mathrm{RC}_{5} \mathrm{H}_{4}\right)_{2} \mathrm{TiS}_{5}(\mathrm{R}=\mathrm{H}, \mathrm{Me})$ with $\mathrm{PPh}_{3}$, and $\left[\left(\eta^{5}-\mathrm{MeC}_{5} \mathrm{H}_{4}\right) \mathrm{Ru}\left(\mathrm{PPh}_{3}\right)_{2} \mathrm{~S}\right]_{2}\left[\mathrm{SbF}_{6}\right]_{2}$ with $\left(\mathrm{NBu}_{4}\right)_{2} \mathrm{~S}_{6}$ respectively. The tetrameric $\mathrm{Al}(\mathrm{I})$ compound $(\mathrm{Cp} * \mathrm{Al})_{4}{ }^{24}$ can be oxidized with $\mathrm{Se}$ and Te to afford heterocubanes $\left(\mathrm{Cp}^{*} \mathrm{Al}\right)_{4} \mathrm{E}_{4}(\mathrm{E}=\mathrm{Se}, \mathrm{Te}) .{ }^{29}$ However no reaction was carried out between $\mathrm{S}$ and $\left(\mathrm{Cp}^{*} \mathrm{Al}\right)_{4} \cdot{ }^{24}$ Herein we describe the synthesis and structural characterisation of $\operatorname{LAl}\left(\mu-S_{3}\right)_{2} \operatorname{AlL}(\mathbf{1 5})$ containing two $\left(\mu-S_{3}\right)$ chains.

Compound 15 was synthesised by the reaction of $\mathbf{1 2}$ with sulphur in a molar ratio of 2:6 (the ratio corresponds to the stoichiometry of S) (Scheme 10). Cold toluene was added to the mixture of $\mathbf{1 2}$ and sulphur at $-78^{\circ} \mathrm{C}$. After several minutes a suspension was obtained which was kept at $-78^{\circ} \mathrm{C}$ for $2 \mathrm{~h}$. Subsequently, the suspension was slowly warmed to room temperature under formation of more precipitate. Compound $\mathrm{LAl}(\mu-\mathrm{S})_{2} \mathrm{AlL}^{35 \mathrm{~b}}$ was isolated from the precipitate and characterized by its characteristic melting point and EI mass spectrum. Pale yellow crystals of $\mathbf{1 5}$ were obtained from the concentrated filtrate at $4{ }^{\circ} \mathrm{C}$, as 


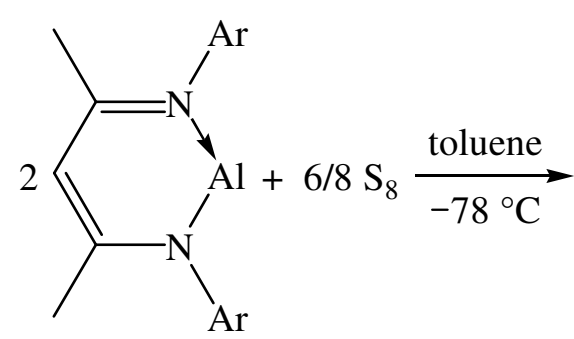

12

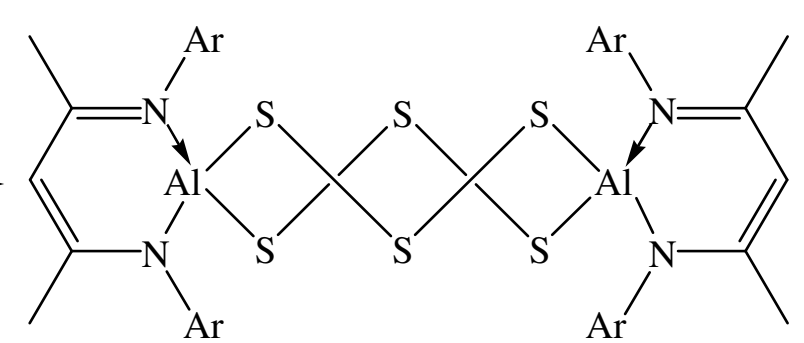

15

$\mathrm{Ar}=2,6-i \mathrm{Pr}_{2} \mathrm{C}_{6} \mathrm{H}_{3}$

\section{Scheme 10}

well as at room temperature. It is noted that even when the above reaction was employed in a molar ratio of 2:3 (the ratio corresponds to the stoichiometry of $S$ ), the isolated product is also 15, however in low yield (about $10 \%$ ). Compound 15 was characterised by ${ }^{1} \mathrm{H},{ }^{13} \mathrm{C}$ NMR spectroscopy, EI mass spectrometry, and elemental analysis. The most intense peak in the EI mass spectrum of $\mathbf{1 5}$ appears at $\mathrm{m} / z, 508\left[M-\mathrm{LAlS}_{4}\right]^{+}$. The signals at $540(38 \%)$ and $572(15$ $\%)$ are assigned to the $\left[M-\mathrm{LAlS}_{3}\right]^{+}$and $\left[M-\mathrm{LAlS}_{2}\right]^{+}$fragments respectively. $\mathbf{1 5}$ is sparingly soluble in benzene- $\mathrm{d}_{6}$, and the solubility does not improve even when heated, it does not dissolve in hexane and pentane. When the reaction mixture or the isolated compound is exposed to traces of moisture, the free ligand $\mathrm{LH}$ can be detected by ${ }^{1} \mathrm{H}$ NMR investigation.

\subsubsection{Molecular structure of 15}

Single crystals of $\mathbf{1 5}$ suitable for X-ray structural analysis were obtained in toluene at $4{ }^{\circ} \mathrm{C}$. Compound 15 crystallises in the monoclinic space group $P 2_{1} / n$ with two molecules of toluene. Figure 15 shows the molecular structure of $\mathbf{1 5}$. Two $\left(\mu-\mathrm{S}_{3}\right)$ chains are connecting two $\mathrm{Al}$ atoms to form an aluminum polysulfide with an $\mathrm{Al}_{2} \mathrm{~S}_{6}$ eight-membered ring. The two $\mathrm{L}$ 
ligands are almost coplanar. The symmetry of the structure is $\mathrm{Ci}$. Compared to the $\mathrm{S}_{8}$ structure, ${ }^{80}$ the two $S_{3}$ units in the $S_{8}$ structure are eclipsed, while in $\mathbf{1 5}$ they are staggered, thus we cannot simply argue that the two $\mathrm{Al}$ atoms are replacing the corresponding $\mathrm{S}$ atoms in $\mathrm{S}_{8}$. Selected bond lengths and angles are shown in Table 12. The S-S bonds (av. $2.08 \AA$ ) are slightly longer than those of $\mathrm{S}_{8}(\operatorname{av} 2.05 \AA),{ }^{80}\left[\left(\eta^{5}-\mathrm{MeC}_{5} \mathrm{H}_{4}\right)_{2} \operatorname{Ti}\left(\mu-\mathrm{S}_{3}\right)\right]_{2}$ (av. $\left.2.06 \AA\right)^{78}$ and $\left[\left(\eta^{5}-\mathrm{MeC}_{5} \mathrm{H}_{4}\right) \mathrm{Ru}\left(\mathrm{PPh}_{3}\right)\left(\mu-\mathrm{S}_{3}\right)\right]_{2}$ (av. $\left.2.05 \AA\right) .{ }^{79}$ The Al-S bonds (av. $2.24 \AA$ ) are comparable with those of dimeric $\operatorname{LAl}(\mu-\mathrm{S})_{2} \mathrm{AlL}$ (av $\left.2.24 \AA\right)^{35 \mathrm{~b}}$ and $\mathrm{LAl}(\mathrm{SH})_{2}($ av. $2.22 \AA){ }^{36}$ The Al-N bond length (av. $1.89 \AA$ ) falls within the range of those in aluminum derivatives bearing the $\mathrm{L}$ ligand. ${ }^{19 a}$ The S-S-S angle $\left(104.7^{\circ}\right)$ is close to those found in $\left[\left(\eta^{5}-\mathrm{MeC}_{5} \mathrm{H}_{4}\right)_{2} \mathrm{Ti}\left(\mu-\mathrm{S}_{3}\right)\right]_{2}$ $\left(109.1^{\mathrm{o}}\right)^{78}$ and $\left[\left(\eta^{5}-\mathrm{MeC}_{5} \mathrm{H}_{4}\right) \mathrm{Ru}\left(\mathrm{PPh}_{3}\right)\left(\mu-\mathrm{S}_{3}\right)\right]_{2}\left(105.2^{\mathrm{o}}\right) .^{79}$

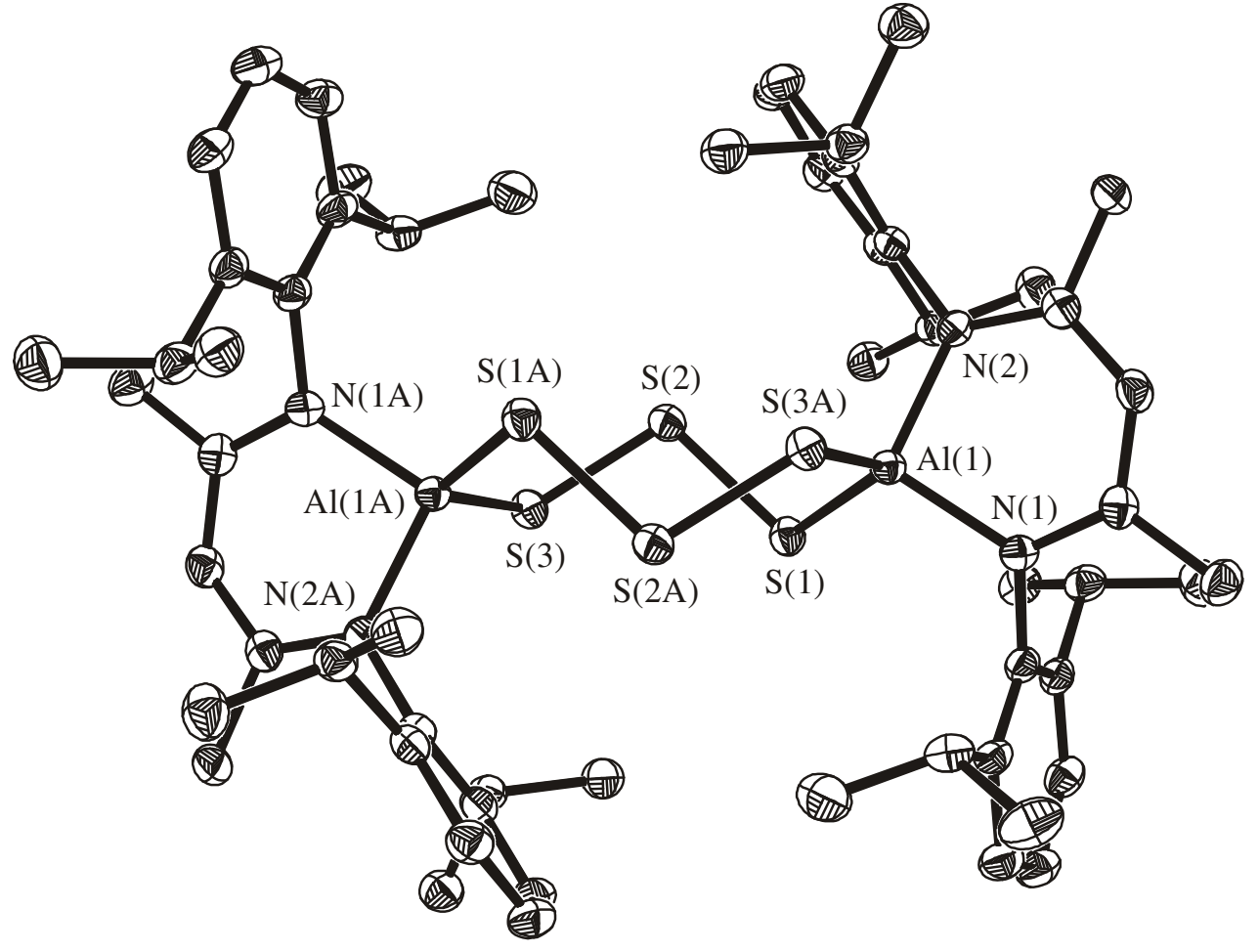

Figure 15. Thermal ellipsoids plot of $\mathbf{1 5}$ showing the atoms at the $50 \%$ probability level. $\mathrm{H}$ atoms and solvent molecules are omitted for clarity. 
Table 12. Selected bond lengths $(\AA)$ and angles $\left(^{\circ}\right)$ for $\mathbf{1 5}$.

\begin{tabular}{llll}
\hline $\mathrm{Al}(1)-\mathrm{N}(1)$ & $1.882(2)$ & $\mathrm{S}(1)-\mathrm{Al}(1)-\mathrm{S}(3 \mathrm{~A})$ & $116.9(1)$ \\
$\mathrm{Al}(1)-\mathrm{N}(2)$ & $1.904(2)$ & $\mathrm{N}(2)-\mathrm{Al}(1)-\mathrm{S}(1)$ & $117.33(6)$ \\
$\mathrm{Al}(1)-\mathrm{S}(1)$ & $2.223(1)$ & $\mathrm{N}(1)-\mathrm{Al}(1)-\mathrm{S}(3 \mathrm{~A})$ & $112.39(6)$ \\
$\mathrm{Al}(1)-\mathrm{S}(3 \mathrm{~A})$ & $2.248(1)$ & $\mathrm{N}(2)-\mathrm{Al}(1)-\mathrm{S}(3)$ & $104.93(5)$ \\
$\mathrm{S}(1)-\mathrm{S}(2)$ & $2.095(1)$ & $\mathrm{S}(3)-\mathrm{S}(2)-\mathrm{S}(1)$ & $104.7(1)$ \\
$\mathrm{S}(2)-\mathrm{S}(3)$ & $2.073(1)$ & $\mathrm{S}(2)-\mathrm{S}(1)-\mathrm{Al}(1)$ & $98.0(1)$ \\
$\mathrm{N}(1)-\mathrm{C}(2)$ & $1.351(3)$ & $\mathrm{S}(2)-\mathrm{S}(3)-\mathrm{Al}(1 \mathrm{~A})$ & $107.18(3)$ \\
$\mathrm{C}(2)-\mathrm{C}(3)$ & $1.389(3)$ & $\mathrm{C}(2)-\mathrm{N}(1)-\mathrm{Al}(1)$ & $119.92(13)$ \\
$\mathrm{C}(3)-\mathrm{C}(4)$ & $1.402(3)$ & $\mathrm{N}(1)-\mathrm{C}(2)-\mathrm{C}(3)$ & $122.47(18)$ \\
$\mathrm{N}(2)-\mathrm{C}(4)$ & $1.337(3)$ & $\mathrm{C}(2)-\mathrm{C}(3)-\mathrm{C}(4)$ & $128.0(2)$ \\
$\mathrm{N}(1)-\mathrm{Al}(1)-\mathrm{N}(2)$ & $97.7(1)$ & $\mathrm{N}(2)-\mathrm{C}(4)-\mathrm{C}(3)$ & $122.99(19)$ \\
$\mathrm{N}(1)-\mathrm{Al}(1)-\mathrm{S}(1)$ & $106.17(6)$ & $\mathrm{C}(4)-\mathrm{N}(2)-\mathrm{Al}(1)$ & $119.95(13)$ \\
\hline
\end{tabular}

\subsubsection{Theoretical calculation for 15}

The $\mathrm{S}_{8}$ ring can have different cleavage patterns and thus forms various types of structures. ${ }^{76 \mathrm{a}}$ For $\mathrm{L}_{2} \mathrm{Al}_{2} \mathrm{~S}_{\mathrm{n}}$ species the product with $\mathrm{n}=2$ is already known, ${ }^{35 \mathrm{~b}}$ and herein compound 15 has $n=6$. The theoretical calculation was carried out to estimate the relative stability of the compounds with $n=2-8$. The method used is RI-BP86/TZVP within the TURBOMOLE ${ }^{45}$ program. The optimised structure of $\mathrm{L}_{2} \mathrm{Al}_{2} \mathrm{~S}_{6}$ is in good agreement with the X-ray values for 15 (mean deviation $<0.04 \AA$ ), which shows the reliability of the selected theoretical method. In the calculation the $\mathrm{CHMe}_{2}$ groups of the ligand $\mathrm{L}$ were replaced by $\mathrm{H}$ atoms. The relative stability of $\mathrm{L}_{2} \mathrm{Al}_{2} \mathrm{~S}_{\mathrm{n}}$ was estimated by the reaction energy of $2 \mathrm{LAl}+\mathrm{n} / 8$ $\mathrm{S}_{8} \rightarrow \mathrm{L}_{2} \mathrm{Al}_{2} \mathrm{~S}_{\mathrm{n}}$. The calculated reaction energies are listed in Table 13. All reactions are exothermic. Compound $\mathrm{L}_{2} \mathrm{Al}_{2} \mathrm{~S}_{2}{ }^{35 b}$ is the most stable one. However, there are quite a few 
conformations with only a little smaller reaction energies, and thus thermodynamically they are all possible. Most $\mathrm{L}_{2} \mathrm{Al}_{2} \mathrm{~S}_{\mathrm{n}}$ species prefer only one bridging $\mathrm{S}$ atom, while all the other $\mathrm{S}$ atoms are arranged in the second bridge (Table 13). We could isolate 15 but not the (theoretically favored) S1 S5 isomer, this might be due to the very low solubility of the latter species.

Table 13. The reaction energy of $\mathrm{L}_{2} \mathrm{Al}_{2} \mathrm{~S}_{\mathrm{n}}(\mathrm{n}=2-8)$ is obtained from $E\left(\mathrm{~L}_{2} \mathrm{Al}_{2} \mathrm{~S}_{\mathrm{n}}\right)-2 E(\mathrm{LAl})-$ $\mathrm{n} / 8 E\left(\mathrm{~S}_{8}\right)$. The notes below the energies show the conformations. For example, S3 S4 means one bridge has three $\mathrm{S}$ atoms, while the other one has four $\mathrm{S}$ atoms.

\begin{tabular}{|l|l|l|l|l|l|l|l|}
\hline $\mathrm{n}$ & 2 & 3 & 4 & 5 & 6 & 7 & 8 \\
\hline Reaction & -648.7 & -641.6 & -644.9 & -602.0 & -621.5 & -594.6 & -609.2 \\
Energy & S1 S1 & S1 S2 & S1 S3 & S1 S4 & S1 S5 & S1 S6 & S1 S7 \\
$(\mathrm{kJ} / \mathrm{mol})$ & & & & & & & \\
& & & -571.7 & -581.8 & -608.9 & -408.5 & -257.0 \\
& & & S2 S2 & S2 S3 & S3 S3 & S3 S4 & S4 S4 \\
\hline
\end{tabular}

Therefore, the theoretical work shows that all $\mathrm{L}_{2} \mathrm{Al}_{2} \mathrm{~S}_{\mathrm{n}}(\mathrm{n}=2-8)$ species have rather stable conformations (can be more than one). ${ }^{81}$ They may coexist in the product, and under different reaction conditions another species may be preferentially formed. To obtain a single crystal out of such a mixture is difficult except for $n=2$ where one can use excess of $\mathbf{1 2}$ to react with sulphur.

In summary, we report herein the first compound of Group 13 with two $\left(\mu-S_{3}\right)$ chains connecting two aluminum atoms under formation of an eight-membered $\mathrm{Al}_{2} \mathrm{~S}_{6}$ ring. Studies of other possible conformations of $\mathrm{L}_{2} \mathrm{Al}_{2} \mathrm{~S}_{\mathrm{n}}$ estimated by calculation are currently under investigation in our laboratory. 


\section{Summary and Outlook}

\subsection{Summary}

The focus of the work reported here has been on the synthesis, structures and reactions of aluminum(I) and aluminum(III) compounds with organic species. In this thesis bulky bidentate salicylaldiminato, $\beta$-diketiminato, tert-butyl and adamantyl groups have been employed as supporting moieties for aluminum compounds. The experimental results demonstrate that steric bulk and intramolecular hydrogen bond can stabilise some unusual organoaluminum compounds.

The first aluminum monohydride (3- $\left.t \mathrm{Bu}-5-\mathrm{Me}-2-(\mathrm{O}) \mathrm{C}_{6} \mathrm{H}_{2} \mathrm{CH}_{2}-\mathrm{N}-2,6-i \mathrm{Pr}_{2} \mathrm{C}_{6} \mathrm{H}_{3}\right)$ $\mathrm{AlH}\left(\mathrm{NMe}_{3}\right)(2)$ bearing a bidentate $[\mathrm{N}, \mathrm{O}]$ ligand has been prepared from the salicylaldimine [3- $t \mathrm{Bu}-5-\mathrm{Me}-2-(\mathrm{OH}) \mathrm{C}_{6} \mathrm{H}_{2} \mathrm{CH}=\mathrm{N}-2,6-i \mathrm{Pr}_{2} \mathrm{C}_{6} \mathrm{H}_{3}$ ] (1) and $\mathrm{AlH}_{3} \cdot \mathrm{NMe}_{3}$. Noteworthy, during the formation of $\mathbf{2}$ in addition to the elimination of hydrogen a hydrogen migration from the aluminum center to the ligand backbone occurred at the $\mathrm{CH}=\mathrm{N}$ double bond to yield a $\mathrm{CH}_{2} \mathrm{~N}$ single bond.

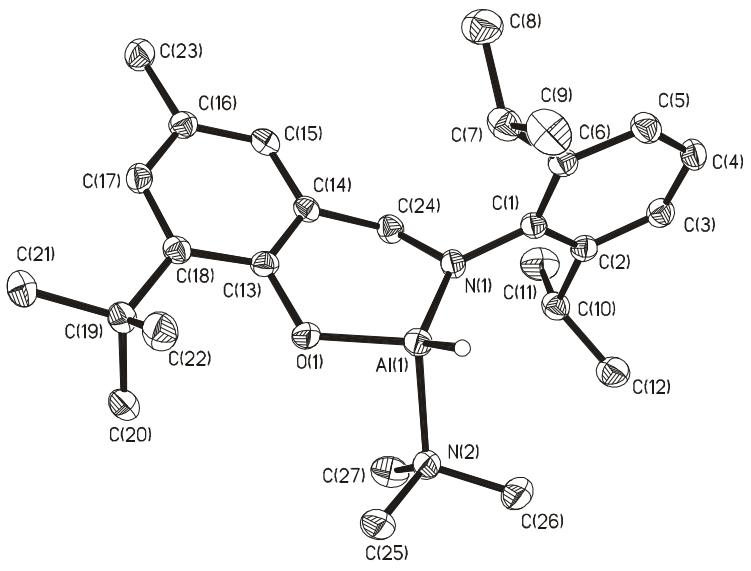

\section{Structure of 2}

2 reacts with elemental $S$ and Se respectively to afford the dimeric chalcogenide [(3- $\left.\left.t \mathrm{Bu}-5-\mathrm{Me}-2-(\mathrm{O}) \mathrm{C}_{6} \mathrm{H}_{2} \mathrm{CH}_{2}-\mathrm{NH}-2,6-i \mathrm{Pr}_{2} \mathrm{C}_{6} \mathrm{H}_{3}\right) \mathrm{Al}(\mu-\mathrm{E})\right]_{2}[\mathrm{E}=\mathrm{S}$ (3), Se (4)]. A possible 
reaction mechanism is discussed. We assume that during the formation of $\mathbf{3}$ and $\mathbf{4}$ a reactive intermediate $\left[\left(3-t \mathrm{Bu}-5-\mathrm{Me}-2-(\mathrm{O}) \mathrm{C}_{6} \mathrm{H}_{2} \mathrm{CH}_{2}-\mathrm{N}-2,6-i \mathrm{Pr}_{2} \mathrm{C}_{6} \mathrm{H}_{3}\right) \mathrm{Al}(\mathrm{EH})\left(\mathrm{NMe}_{3}\right)\right](\mathrm{E}=\mathrm{S}, \mathrm{Se})$ is formed which dimerises to $\left[\left(3-t \mathrm{Bu}-5-\mathrm{Me}-2-(\mathrm{O}) \mathrm{C}_{6} \mathrm{H}_{2} \mathrm{CH}_{2}-\mathrm{N}-2,6-i \mathrm{Pr}_{2} \mathrm{C}_{6} \mathrm{H}_{3}\right) \mathrm{Al}(\mu-\mathrm{EH})\right]_{2}$ with elimination of $\mathrm{NMe}_{3}$. The unstable $\left[\left(3-t \mathrm{Bu}-5-\mathrm{Me}-2-(\mathrm{O}) \mathrm{C}_{6} \mathrm{H}_{2} \mathrm{CH}_{2}-\mathrm{N}-2,6-i \mathrm{Pr}_{2} \mathrm{C}_{6} \mathrm{H}_{3}\right) \mathrm{Al}(\mu-\mathrm{EH})\right]_{2}$ is converted to $\mathbf{3}$ and $\mathbf{4}$ under heating. The molecular structures of $\mathbf{3}$ and $\mathbf{4}$ show that both of them have a dimeric structure featuring a fused planar four-membered ring with a central $\mathrm{Al}_{2} \mathrm{E}_{2}$ core. Attempts to obtain single crystals from the reaction of $\mathbf{2}$ with Te was unsuccessful.

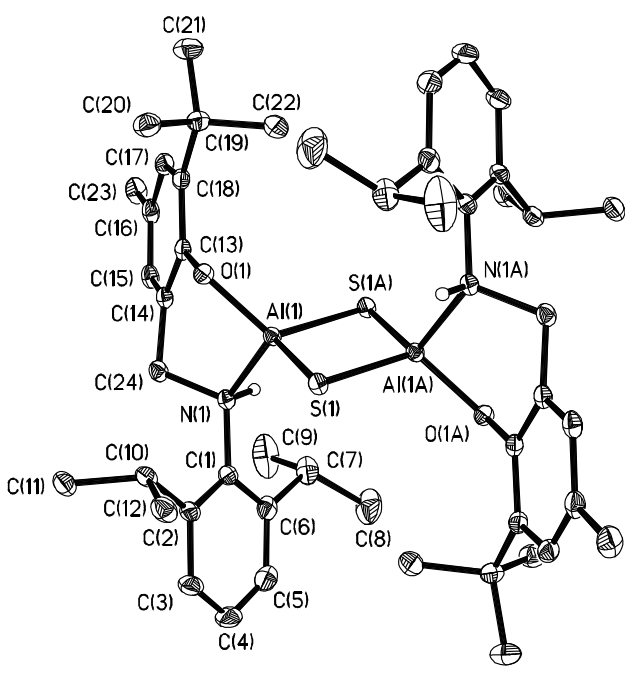

Structure of 3

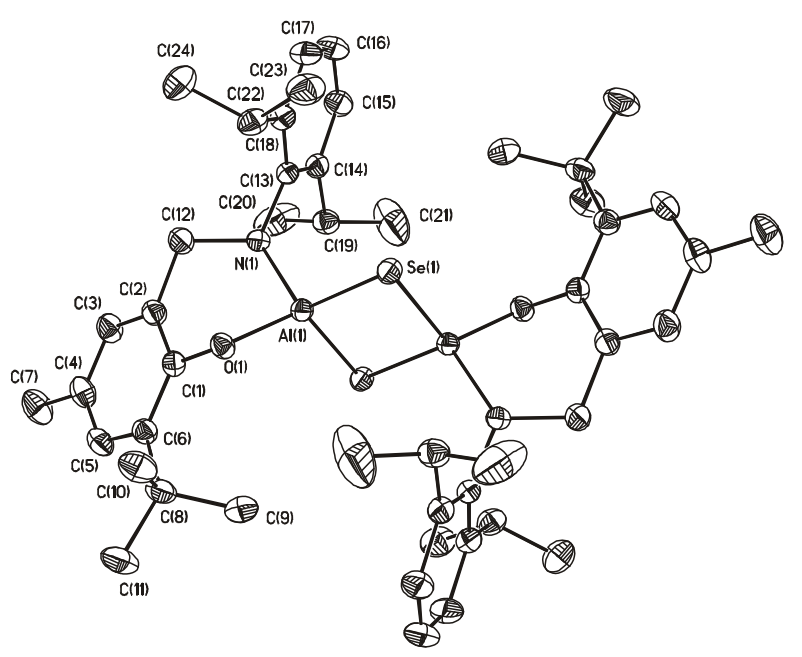

Structure of 4

The reaction of aluminum dihydride $\mathrm{LAlH}_{2}\left(\mathrm{~L}=\mathrm{HC}(\mathrm{CMeNAr})_{2}, \mathrm{Ar}=2,6-i \mathrm{Pr}_{2} \mathrm{C}_{6} \mathrm{H}_{3}\right)(\mathbf{5})$ and tert-butylisocyanate in the presence of trace amounts of water and from $\mathbf{5}$ and $\mathrm{LAlH}(\mathrm{OCH}=\mathrm{N}-t \mathrm{Bu})(\mathbf{6})$ with water, respectively, afforded the first aluminoxane hydroxide $\mathrm{LAl}(\mathrm{OH}) \mathrm{OAlL}(\mathrm{OCH}=\mathrm{N}-t \mathrm{Bu})(\mathbf{8})$. The important point is to control strictly the amount of water during the reaction, an excess of water will decompose product $\mathbf{8}$. The intramolecular hydrogen bond and the bulky L ligand at the aluminum center stabilise $\mathbf{8}$ to be a binuclear 
aluminoxane with terminal $\mathrm{OH}$ group. Treatment of $\mathbf{5}$ with tert-butylisocyanate in a ratio of 1:1 or 1:2 gave the nucleophilic addition product 6 or $\mathrm{LAl}(\mathrm{OCH}=\mathrm{N}-t \mathrm{Bu})_{2}(\mathbf{7})$.

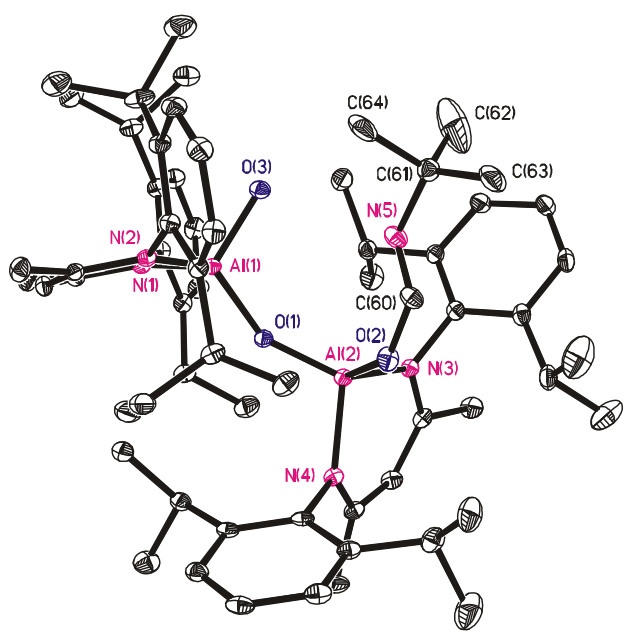

\section{Structure of 8}

The heptameric aluminum imide $\left(\mathrm{RCH}_{2} \mathrm{NAlH}\right)_{7}(\mathbf{9})$ was isolated from the reaction of the bulky nitrile $\mathrm{RCN}\left(\mathrm{R}=1\right.$-adamantyl) with $\mathrm{AlH}_{3} \cdot \mathrm{NMe}_{3}$ in boiling toluene. 9 is the first heptameric aluminum imide with $\mathrm{Al}-\mathrm{H}$ bonds, and the second imide with an $\mathrm{Al}_{7} \mathrm{~N}_{7}$ core. Nitriles with less bulky $\mathrm{R}$ groups led to the formation of hexameric imides. The possible reason of this phenomenon is discussed.

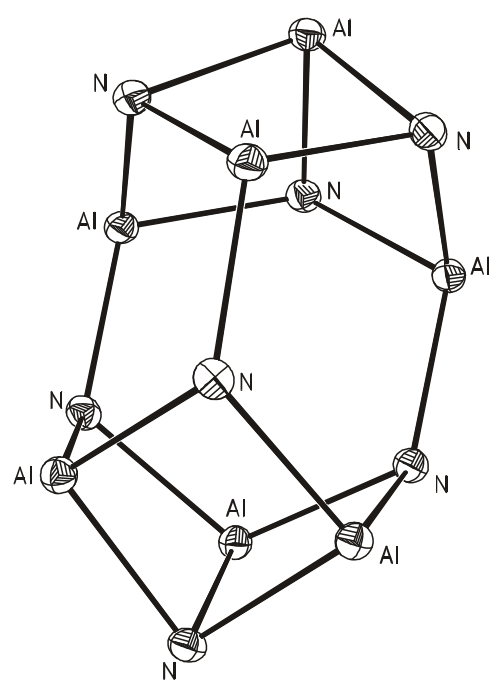

Core structure of 9

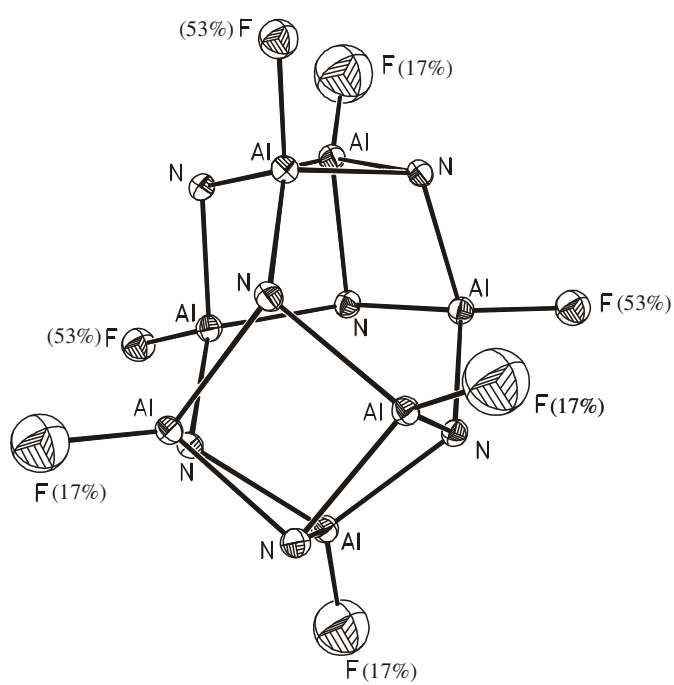

Core structure of 10 
Fluorination of 9 with $\mathrm{Me}_{3} \mathrm{SnF}$ was carried out at room temperature in $\mathrm{CH}_{2} \mathrm{Cl}_{2}$ or refluxing toluene to obtain a partially fluorinated compound $\left(\mathrm{RCH}_{2} \mathrm{NAl}\right)_{7} \mathrm{~F}_{2.26} \mathrm{H}_{4.74}(\mathrm{R}=$ 1-adamantyl) (10). The reaction of 9 with $\mathrm{Me}_{3} \mathrm{SiCl}$ and $\mathrm{Me}_{3} \mathrm{SiBr}$ both afforded also partially substituted products. The fluorination reaction using $\mathrm{Me}_{3} \mathrm{SnF}$ was applied to the cluster $\left(t \mathrm{BuNCH}_{2} \mathrm{AlH}\right)_{4}$ to yield the corresponding tetrafluoro compound $\left(t-\mathrm{BuNCH}_{2} \mathrm{AlF}\right)_{4}(\mathbf{1 1}) . \mathbf{1 0}$ and $\mathbf{1 1}$ are the first two aggregates containing only terminal Al-F bonds.

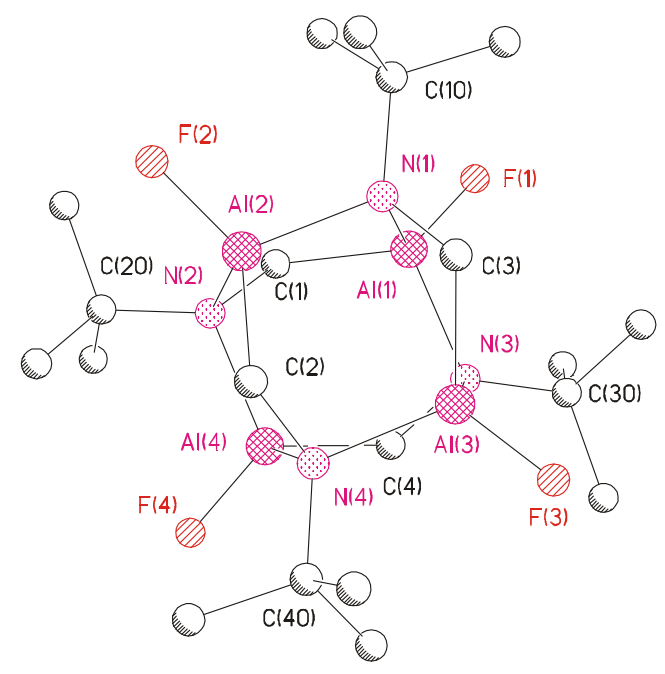

Structure of 11

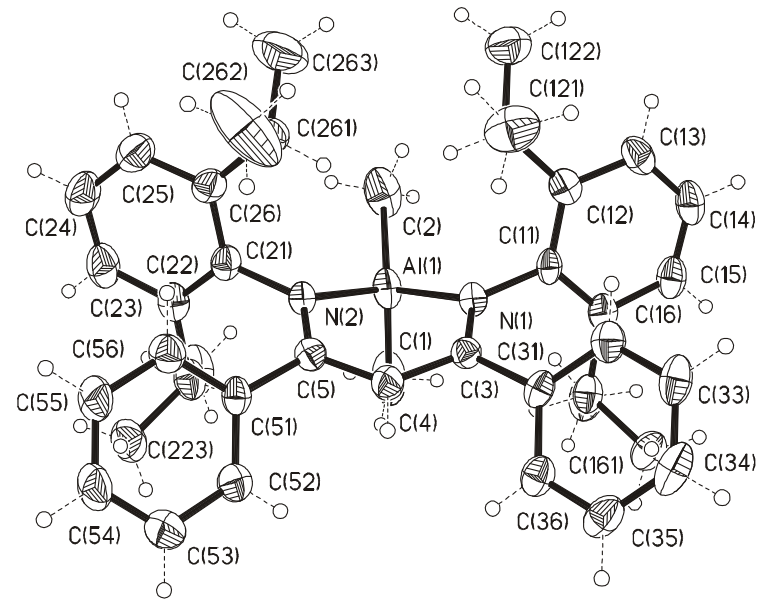

Structure of 13

Compound 13 was synthesised from the reaction of $\mathrm{AlMe}_{3}$ with $\left[\mathrm{HC}(\mathrm{CPhNAr})_{2}\right] \mathrm{H}$ in refluxing toluene in a 1:1 ratio. $\mathbf{1 3}$ was characterised by NMR and elemental analyses as well as X-ray structural analyses.

The reactive monomeric aluminum(I) compound $\mathrm{LAl}^{\mathrm{I}}\left(\mathrm{L}=\mathrm{HC}(\mathrm{CMeNAr})_{2}, \mathrm{Ar}=\right.$ 2,6-i $\left.\operatorname{Pr}_{2} \mathrm{C}_{6} \mathrm{H}_{3}\right)(\mathbf{1 2})$ was reacted with white phosphorus to yield the first main group complex of composition $\left[\mathrm{HC}(\mathrm{CMeNAr})_{2}\right]_{2} \mathrm{Al}_{2} \mathrm{P}_{4}$ (14) with a formal $\mathrm{P}_{4}^{4-}$ charged species. 14 was 
characterized by ${ }^{1} \mathrm{H},{ }^{13} \mathrm{C},{ }^{27} \mathrm{Al},{ }^{31} \mathrm{P}$ NMR spectroscopy as well as structural analyses. It is sensitive to air and moisture and well soluble in diethyl ether, benzene and toluene. The crystal structure shows that $\mathbf{1 4}$ contains an $\mathrm{Al}_{2} \mathrm{P}_{4}$ core in which two $\mathrm{P}-\mathrm{P}$ edges of the $\mathrm{P}_{4}$ tetrahedron are opened and each is bridged by a LAl moiety. The DFT calculations show that a significant charge transfer from the $\mathrm{Al}$ atoms to $\mathrm{P}_{4}$ occurs and the aluminum is oxidised to +3 from +1 . The ${ }^{27} \mathrm{Al}$ NMR also supports this point.

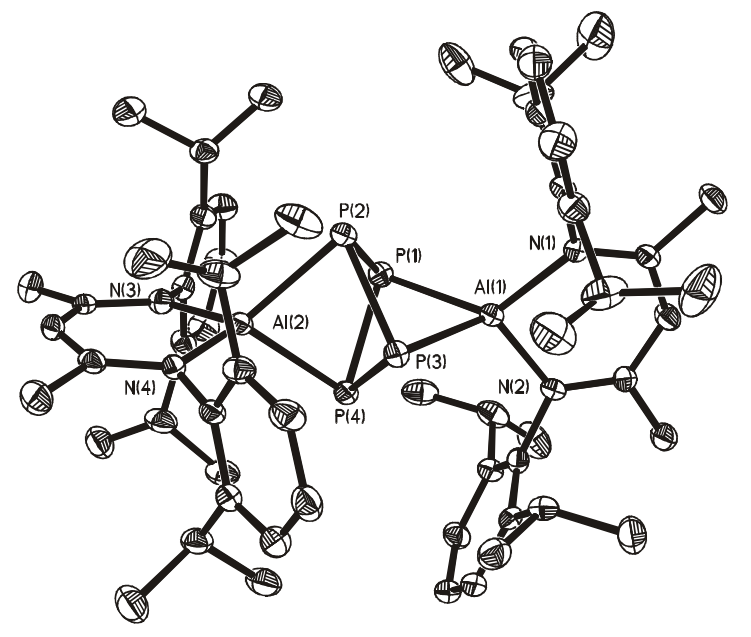

\section{Structure of 14}

Reaction of 12 with elemental sulfur at $-78{ }^{\circ} \mathrm{C}$ affords a bimetallic derivative of the sulfur crown $\mathrm{S}_{8}$ : $\operatorname{LAl}\left(\mu-\mathrm{S}_{3}\right)_{2} \operatorname{AlL}(\mathbf{1 5}) .15$ is extremely sensitive to air and moisture, and it is the first example of a main group cyclic bimetallic compound of the trisulfide ion. Two $\left(\mu-\mathrm{S}_{3}\right)$ chains are connecting two $\mathrm{Al}$ atoms to form an aluminum polysulfide with an $\mathrm{Al}_{2} \mathrm{~S}_{6}$ eight-membered ring. The two ligands are almost coplanar. The symmetry of the structure is Ci. Compared to the $S_{8}$ structure, the two $S_{3}$ units in the $S_{8}$ structure are eclipsed, while in $\mathbf{1 5}$ they are staggered. The theoretical work shows that all $\mathrm{L}_{2} \mathrm{Al}_{2} \mathrm{~S}_{\mathrm{n}}(\mathrm{n}=2-8)$ species from the reaction $2 \mathrm{LAl}+\mathrm{n} / 8 \mathrm{~S}_{8} \rightarrow \mathrm{L}_{2} \mathrm{Al}_{2} \mathrm{~S}_{\mathrm{n}}$ have rather stable conformations (can be more than one). 
These compounds may coexist in the product, and under different reaction conditions other species may be preferentially formed.

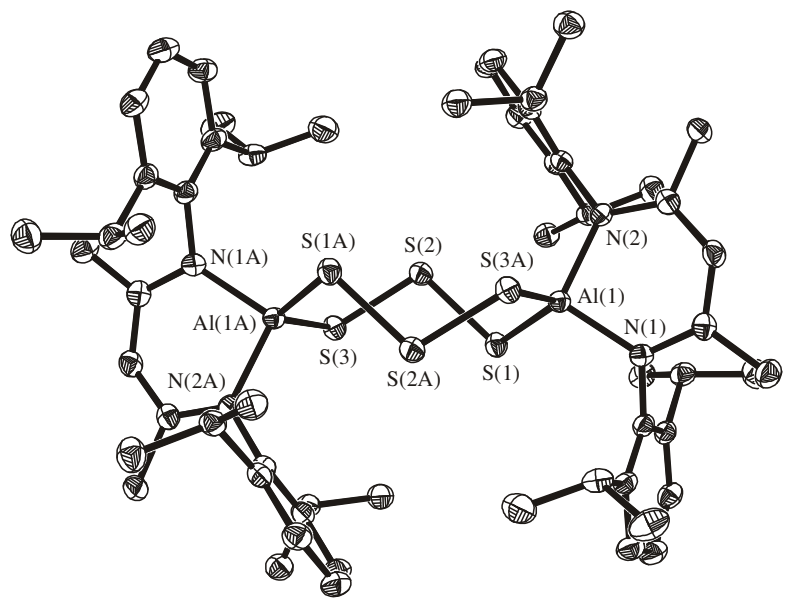

\section{Structure of 15}




\subsection{Outlook}

This thesis reports the synthesis and characterisaton of organoaluminum(I) and aluminum(III) compounds. A more general extension of this work would be:

1. The aluminoxane hydroxide can react with other less bulky organometallic compounds in solution, which provides the possibility for the synthesis of aluminum containing homoor heteroorganometallic compounds and their application for the polymerisation of olefins.

2. The monomeric aluminum(I) is a reactive starting material which can be used as reducing agent to react with group 15 and 16 elements.

3. As a two-electron donor the monomeric aluminum(I) can react with metal carbonyl complexes to replace the carbonyl groups under formation of Al-metal bonds. 


\section{Experimental Section}

\subsection{General procedures}

All experimental manipulations, unless otherwise stated, were carried out in oxygen-free dry dinitrogen atmosphere using Schlenk glassware and techniques. ${ }^{82}$ The handling of solids and the preparation of samples for spectral measurements were carried out inside a MBraun LABMASTER-130 dry-box where the $\mathrm{O}_{2}$ and $\mathrm{H}_{2} \mathrm{O}$ levels were normally kept below 1 ppm. The glassware used in all the manipulations were oven-dried at $150{ }^{\circ} \mathrm{C}$ for a minimum of 14 $\mathrm{h}$, assembled hot, and cooled under high vacuum prior to use. Commercial grade solvents were purified and freshly distilled following conventional procedures prior to use ${ }^{83}$ For the use of highly air- and moisture-sensitive reactions, the solvents were freshly trap-to-trap distilled.

\subsection{Physical measurements}

Melting points of all new compounds were measured on a Büchi melting point B-540 apparatus in sealed capillaries and are uncorrected.

IR spectra were recorded on a Bio-Rad Digilab FTS-7 spectrometer (only characteristic absorptions are reported) and the samples were prepared as Nujol mulls between $\mathrm{KBr}$ plates.

NMR spectra were recorded on Bruker Avance 200, AM 300, MSL 400 (CP-MAS), and Bruker Avance 500 NMR spectrometers. Chemical shifts are reported in ppm external referenced by $\mathrm{SiMe}_{4}$ for ${ }^{1} \mathrm{H},{ }^{13} \mathrm{C}$ nuclei, $\mathrm{CFCl}_{3}$ for ${ }^{19} \mathrm{~F}$, and $85 \% \mathrm{H}_{3} \mathrm{PO}_{4}$ for ${ }^{31} \mathrm{P}$ nuclei. Downfield shifts from the reference are quoted positive, upfield shifts are assigned negative values. All the NMR grade solvents were dried prior to use and the samples for the 
measurements were freshly prepared in a dry-box. Heteroatom NMR spectra were recorded ${ }^{1} \mathrm{H}$ decoupled.

Mass spectra were obtained on Finnigan MAT system 8230 or Varian MAT CH5 mass spectrometers by EI-MS methods.

Elemental analysis were performed at the Analytisches Labor des Instituts für Anorganische Chemie der Universität Göttingen.

Crystal structure determination: Intensity data for compounds 2, 3 and $\mathbf{1 5}$ were collected on a Bruker three-circle diffractometer equipped with a SMART 6000 CCD detector, for $\mathbf{4 , 8}$, 9, 10 and 14 on a Stoe IPDS II two-circle diffractometer, and for $\mathbf{1 1}$ and $\mathbf{1 3}$ on a Siemens-Stoe AED2 four-circle instrument. The data for all the compounds were collected at low temperatures. All structures were solved by direct methods (SHELXS-97) ${ }^{84}$ and refined with all data by full-matrix least-squares methods on $F^{2}{ }^{85}$ The non-hydrogen atoms were refined anisotropically, except those of the highly disordered toluene molecules in $\mathbf{4}$ which were refined isotropically. The hydrogen atoms were included at geometrically idealized positions and refined with the riding model, except for the $\mathrm{Al}-\mathrm{H}$ and $\mathrm{N}-\mathrm{H}$ hydrogen atoms which were located by difference Fourier synthesis and refined isotropically. The toluene molecules in 2 were disordered over two positions and refined with distance restraints and restraints for the anisotropic displacement parameters. Crystal data, data collection details, structural solution and refinement procedures for all compounds are summarized in the tables of section 6 . 


\subsection{Starting Materials}

Commercially available chemicals were purchased from Fluka or Aldrich and used as received. The other compounds used in this thesis were prepared according to published

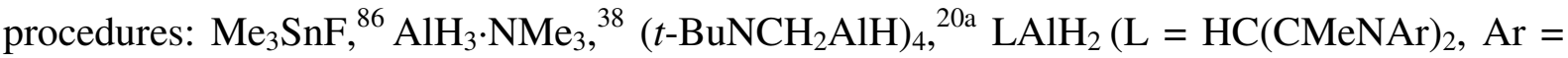
2,6-i $\left.\operatorname{Pr}_{2} \mathrm{C}_{6} \mathrm{H}_{3}\right),{ }^{19 \mathrm{a}} \quad$ 4-methyl-6-tertbutylsalicylaldehyde, ${ }^{5} \quad\left[\mathrm{HC}(\mathrm{CPhNAr})_{2}\right] \mathrm{H} \quad(\mathrm{Ar} \quad=$ 2,6-i $\left.\operatorname{Pr}_{2} \mathrm{C}_{6} \mathrm{H}_{3}\right),{ }^{66 \mathrm{a}}\left[\mathrm{HC}(\mathrm{CMeNAr})_{2}\right]_{2} \mathrm{Al}\left(\mathrm{Ar}=2,6-i \mathrm{Pr}_{2} \mathrm{C}_{6} \mathrm{H}_{3}\right)(\mathbf{1 2}) .{ }^{31}$

\subsection{Synthesis}

\subsection{1. [3-tBu-5-Me-2- $\left.(\mathrm{OH}) \mathrm{C}_{6} \mathrm{H}_{2} \mathrm{CH}=\mathrm{N}-2,6-i \mathrm{Pr}_{2} \mathrm{C}_{6} \mathrm{H}_{3}\right]$ (1)}

2,6-Diisopropylaniline $(4.88 \mathrm{~mL}, 25.9 \mathrm{mmol})$ was added via syringe to a solution of 4-methyl-6-tertbutylsalicylaldehyde (4.97 g, $25.9 \mathrm{mmol})^{5}$ in EtOH (100 mL). Formic acid (5 drops) was added to the resulting solution, and the solution was refluxed for $20 \mathrm{~h}$. After cooling to room temperature the solution was dried over $\mathrm{MgSO}_{4}$ and finally filtered. The volatiles were removed under vacuo. The residue was extracted with $n$-hexane $(15 \mathrm{~mL})$ and stored at $-20{ }^{\circ} \mathrm{C}$ overnight to afford a pure yellow solid. Yield: $90 \%(8.18 \mathrm{~g})$.

M.p.: 97 - $98{ }^{\circ} \mathrm{C}$; IR (nujol): $\tilde{v}=3400 \mathrm{~cm}^{-1}$ (br, O-H stretch), $1620 \mathrm{~cm}^{-1}$ (C=N stretch); ${ }^{1} \mathrm{H}$ NMR (200.13 MHz, $\left.\mathrm{C}_{6} \mathrm{D}_{6},\right): \delta 1.06\left(\mathrm{~d}, 12 \mathrm{H}, J=6.8 \mathrm{~Hz}, \mathrm{CH}\left(\mathrm{CH}_{3}\right)_{2}\right), 1.60(\mathrm{~s}, 9 \mathrm{H}$, $\left.\left.\mathrm{C}\left(\mathrm{CH}_{3}\right)_{3}\right), 2.14\left(\mathrm{~s}, 3 \mathrm{H},\left(\mathrm{CH}_{3}\right)\right), 3.03(\mathrm{sept}, 2 \mathrm{H}, J=6.8 \mathrm{~Hz}, \mathrm{CHMe})_{3}\right), 6.73(\mathrm{~d}, 1 \mathrm{H}, J=2.2 \mathrm{~Hz}$, OAr-H), 7.13 (m, 3 H, NAr- $H$ ), 7.26 (d, $1 \mathrm{H}, J=2.2 \mathrm{~Hz}, \mathrm{OAr}-H), 8.03$ (s, $1 \mathrm{H}, \mathrm{CH}=\mathrm{N}), 13.89$ (s, $1 \mathrm{H},-\mathrm{OH})$; EI-MS $(70 \mathrm{eV}): \mathrm{m} / \mathrm{z}(\%): 351(100) M^{+}$; Elemental analysis for $\mathrm{C}_{24} \mathrm{H}_{33} \mathrm{NO}$ (351.52): Calcd. C, 82.00; H, 9.46; N, 3.98; Found C, 81.67; H, 9.45; N, $4.24 \%$. 


\subsection{2. (3- $\left.t \mathrm{Bu}-5-\mathrm{Me}-2-\mathrm{O}-\mathrm{C}_{6} \mathrm{H}_{2} \mathrm{CH}_{2}-\mathrm{N}-2,6-i \mathrm{Pr}_{2} \mathrm{C}_{6} \mathrm{H}_{3}\right) \mathrm{AlH} \cdot \mathrm{NMe}_{3}(2)$}

$\mathrm{AlH}_{3} \cdot \mathrm{NMe}_{3}(17.2 \mathrm{~mL}$ of a $0.8 \mathrm{M}$ solution in toluene, $13.76 \mathrm{mmol})$ was added at $0{ }^{\circ} \mathrm{C}$ to a solution of $1(3.14 \mathrm{~g}, 8.95 \mathrm{mmol})$ in toluene $(40 \mathrm{~mL})$. The reaction mixture was slowly warmed to room temperature and stirred for additional $15 \mathrm{~h}$. The volatiles were removed in vасио. The crude product was recrystallised from toluene, and the filtrate was kept at $-20{ }^{\circ} \mathrm{C}$ to obtain colourless crystals. Yield: $79 \%(3.10 \mathrm{~g})$.

M.p.: $109-112{ }^{\circ} \mathrm{C}$; IR (nujol): $\tilde{v}=1837 \mathrm{~cm}^{-1}$ (Al-H stretch); ${ }^{1} \mathrm{H}$ NMR (300.13 MHz, $\left.\mathrm{C}_{6} \mathrm{D}_{6},\right): \delta 1.02\left(\mathrm{~d}, 3 \mathrm{H}, J=6.7 \mathrm{~Hz}, \mathrm{CH}\left(\mathrm{CH}_{3}\right)_{2}\right), 1.19\left(\mathrm{~d}, 3 \mathrm{H}, J=6.8 \mathrm{~Hz}, \mathrm{CH}\left(\mathrm{CH}_{3}\right)_{2}\right), 1.43(\mathrm{~d}, 6$ $\left.\mathrm{H}, J=6.8 \mathrm{~Hz}, \mathrm{CH}\left(\mathrm{CH}_{3}\right)_{2}\right), 1.72\left(\mathrm{~s}, 9 \mathrm{H}, \mathrm{C}\left(\mathrm{CH}_{3}\right)_{3}\right), 1.79\left(\mathrm{~s}, 9 \mathrm{H}, \mathrm{N}\left(\mathrm{CH}_{3}\right)_{3}\right), 2.26\left(\mathrm{~s}, 3 \mathrm{H},\left(\mathrm{CH}_{3}\right)\right)$, 3.72 (sept, $2 \mathrm{H}, J=6.8 \mathrm{~Hz}, \mathrm{CHMe}$ ) $, 3.86\left(\mathrm{~d}, 1 \mathrm{H}, J=14.6 \mathrm{~Hz}, \mathrm{CH}_{2} \mathrm{~N}\right), 4.69(\mathrm{~d}, 1 \mathrm{H}, J=14.6$ $\left.\mathrm{Hz}, \mathrm{CH}_{2} \mathrm{~N}\right), 6.65(\mathrm{~d}, 1 \mathrm{H}, J=1.7 \mathrm{~Hz}, \mathrm{OAr}-H), 6.99-7.18(\mathrm{~m}, 4 \mathrm{H}, \mathrm{NAr}-H, \mathrm{OAr}-H)$; EI -MS (70 $\mathrm{eV}): m / \mathrm{z}(\%)$ only $\mathrm{CH}$ fragments; Elemental analysis for $\mathrm{C}_{27} \mathrm{H}_{43} \mathrm{AlN}_{2} \mathrm{O}$ (438.62): Calcd. C, 73.93; H, 9.88; N, 6.39; Found: C, 74.29; H 9.51; N, $5.53 \%$.

\subsection{3. $\left[\left(3-t \mathrm{Bu}-5-\mathrm{Me}-2-\mathrm{O}-\mathrm{C}_{6} \mathrm{H}_{2} \mathrm{CH}_{2}-\mathrm{NH}-2,6-i \mathrm{Pr}_{2} \mathrm{C}_{6} \mathrm{H}_{3}\right) \mathrm{Al}(\mu-\mathrm{S})\right]_{2}(3)$}

Toluene $(20 \mathrm{~mL})$ was added to a mixture of $2(0.56 \mathrm{~g}, 1.28 \mathrm{mmol})$ and $\mathrm{S}_{8}(0.04 \mathrm{~g}, 1.28$ mmol), and the resulting solution was warmed to $60{ }^{\circ} \mathrm{C}$ and stirred for $15 \mathrm{~h}$. After cooling to room temperature the yellow-green solution was filtered and the filtrate was concentrated to ca. $8 \mathrm{~mL}$. Yellow crystals were obtained after storing the resulting solution at $-20{ }^{\circ} \mathrm{C}$ for 5 days. Yield: $62 \%$ (0.72 g).

M.p.: $121{ }^{\circ} \mathrm{C}$ dec; IR (nujol): $\tilde{v}=3175 \mathrm{~cm}^{-1}$ (N-H stretch); ${ }^{1} \mathrm{H}$ NMR $(300.13 \mathrm{MHz}$, $\left.\mathrm{C}_{6} \mathrm{D}_{6},\right): \delta 0.88,0.92,1.09,1.14\left(\mathrm{~d}, 24 \mathrm{H}, J=6.8 \mathrm{~Hz}, \mathrm{CH}\left(\mathrm{CH}_{3}\right)_{2}\right), 1.52(\mathrm{~s}, 2 \mathrm{H}, \mathrm{NH}), 1.45,1.71$ 
(s, $\left.18 \mathrm{H}, \mathrm{C}\left(\mathrm{CH}_{3}\right)_{3}\right), 2.10,2.18\left(\mathrm{~s}, 6 \mathrm{H},\left(\mathrm{CH}_{3}\right)\right), 3.15,3.25,3.41,3.57$ (sept, $4 \mathrm{H}, J=6.8 \mathrm{~Hz}$,

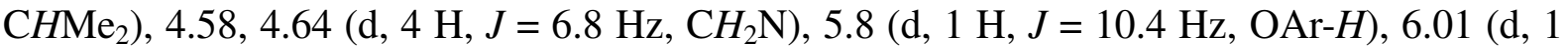
$\mathrm{H}, J=10.4 \mathrm{~Hz}, \mathrm{OAr}-H), 6.40(\mathrm{~d}, 1 \mathrm{H}, J=1.7 \mathrm{~Hz}, \mathrm{OAr}-H), 6.51(\mathrm{~d}, 1 \mathrm{H}, J=1.8 \mathrm{~Hz}, \mathrm{OAr}-H)$, 7.01-7.15 (m, $6 \mathrm{H}, \mathrm{NAr}-H)$; EI-MS (70 eV): $m / z(\%) 822(12)(M-\mathrm{H})^{+}, 162(100)\left(i \mathrm{Pr}_{2} \mathrm{C}_{6} \mathrm{H}_{4}\right)$; Elemental analysis for $\mathrm{C}_{48} \mathrm{H}_{68} \mathrm{Al}_{2} \mathrm{~N}_{2} \mathrm{O}_{2} \mathrm{~S}_{2}$ (823.16): Calcd. C, 70.04; H, 8.33; N, 3.40; Found C, $70.75 ; \mathrm{H}, 8.46 ; \mathrm{N}, 3.50 \%$.

\subsection{4. $\left[\left(3-t \mathrm{Bu}-5-\mathrm{Me}-2-\mathrm{O}-\mathrm{C}_{6} \mathrm{H}_{2} \mathrm{CH}_{2}-\mathrm{NH}-2,6-i \mathrm{Pr}_{2} \mathrm{C}_{6} \mathrm{H}_{3}\right) \mathrm{Al}(\mu-\mathrm{Se})\right]_{2}(4)$}

Toluene $(30 \mathrm{~mL})$ was added to a mixture of $2(0.77 \mathrm{~g}, 1.75 \mathrm{mmol})$ and $\mathrm{Se}(0.28 \mathrm{~g}, 3.54$ mmol). The solution was refluxed for $2 \mathrm{~h}$, unreacted Se was removed by filtration. The filtrate was concentrated to ca. $8 \mathrm{~mL}$ and kept at $0{ }^{\circ} \mathrm{C}$ to obtain yellow crystals. Yield: $60 \%(1.06 \mathrm{~g})$.

M.p.: $118{ }^{\circ} \mathrm{C}$ dec; IR (nujol): $\tilde{V}=3220 \mathrm{~cm}^{-1}$ (N-H stretch); ${ }^{1} \mathrm{H}$ NMR $(300.13 \mathrm{MHz}$, $\left.\mathrm{C}_{6} \mathrm{D}_{6},\right): \delta 0.87,0.94,1.14,1.44\left(\mathrm{~d}, 24 \mathrm{H}, J=6.8 \mathrm{~Hz}, \mathrm{CH}\left(\mathrm{CH}_{3}\right)_{2}\right), 1.50,1.56\left(\mathrm{~s}, 18 \mathrm{H}, \mathrm{C}\left(\mathrm{CH}_{3}\right)_{3}\right)$, $1.88(\mathrm{~s}, 2 \mathrm{H}, \mathrm{NH}), 2.10,2.15\left(\mathrm{~s}, 6 \mathrm{H},\left(\mathrm{CH}_{3}\right)\right), 2.64,3.25,3.43,3.57$ (sept, $4 \mathrm{H}, J=6.6$ $\mathrm{Hz}, \mathrm{CHMe}$ ), 4.35, $4.39\left(\mathrm{~d}, 4 \mathrm{H}, J=6.8 \mathrm{~Hz}, \mathrm{CH}_{2} \mathrm{~N}\right), 6.05(\mathrm{~d}, 1 \mathrm{H}, J=7.8 \mathrm{~Hz}, \mathrm{OAr}-H), 6.21(\mathrm{~d}$, $1 \mathrm{H}, J=7.9 \mathrm{~Hz}, \mathrm{OAr}-H), 6.33(\mathrm{~d}, 1 \mathrm{H}, J=1.8 \mathrm{~Hz}, \mathrm{OAr}-H), 6.47(\mathrm{~d}, 1 \mathrm{H}, J=1.9 \mathrm{~Hz}, \mathrm{OAr}-H)$, 7.01-7.15 (m, $6 \mathrm{H}, \mathrm{NAr}-H)$; EI-MS (70 eV): $m / z(\%) 916(4)(M-\mathrm{H})^{+}, 162(100)\left(i \mathrm{Pr}_{2} \mathrm{C}_{6} \mathrm{H}_{4}\right)$; Elemental analysis for $\mathrm{C}_{62} \mathrm{H}_{84} \mathrm{Al}_{2} \mathrm{~N}_{2} \mathrm{O}_{2} \mathrm{Se}_{2}(1101.23)\left(4 \cdot 2 \mathrm{C}_{7} \mathrm{H}_{8}\right)$ : Calcd. C, 67.62; H, 7.69; N, 2.54; Found C, 67.25; H, 7.81; N, $2.72 \%$.

\subsection{5. $\mathrm{LAIH}(\mathrm{OCH}=\mathrm{N}-t \mathrm{Bu})\left(\mathrm{L}=\mathrm{HC}(\mathrm{CMeNAr})_{2}, \mathrm{Ar}=2,6-i \mathrm{Pr}_{2} \mathrm{C}_{6} \mathrm{H}_{3}\right)(6)$}

Tert-butylisocyanate $(0.14 \mathrm{~mL}, 1.2 \mathrm{mmol})$ was added by syringe to $\mathrm{LAlH}_{2}(0.55 \mathrm{~g}, 1.25$ 
mmol) (5) in toluene $(20 \mathrm{~mL})$. The solution was refluxed for $1 \mathrm{~h}$. After removal of all the volatiles the residue was recrystallised from pentane. The resulting solution was concentrated to ca $5 \mathrm{~mL}$ and kept at $0{ }^{\circ} \mathrm{C}$ to afford colourless crystals. Yield: $68 \%(0.44 \mathrm{~g})$.

M.p.: $141-143{ }^{\circ} \mathrm{C}$; IR (nujol): $\tilde{v}=1868 \mathrm{~cm}^{-1}$ (Al-H stretch); ${ }^{1} \mathrm{H}$ NMR $(300.13 \mathrm{MHz}$, $\left.\mathrm{C}_{6} \mathrm{D}_{6}\right): \delta 1.07\left(\mathrm{~s}, 9 \mathrm{H}, t \mathrm{C}_{4} H_{9}\right), 1.12\left(\mathrm{~d}, 6 \mathrm{H}, J=6.9 \mathrm{~Hz}, \mathrm{CH}\left(\mathrm{CH}_{3}\right)_{2}\right), 1.18(\mathrm{~d}, 6 \mathrm{H}, J=6.8 \mathrm{~Hz}$, $\left.\mathrm{CH}\left(\mathrm{CH}_{3}\right)_{2}\right), 1.28\left(\mathrm{~d}, 6 \mathrm{H}, J=6.7 \mathrm{~Hz}, \mathrm{CH}\left(\mathrm{CH}_{3}\right)_{2}\right), 1.38\left(\mathrm{~d}, 6 \mathrm{H}, J=6.8 \mathrm{~Hz}, \mathrm{CH}\left(\mathrm{CH}_{3}\right)_{2}\right), 1.55(\mathrm{~s}$, $\left.6 \mathrm{H},\left(\mathrm{CH}_{3}\right)\right), 3.41$ (sept, $4 \mathrm{H}, \mathrm{CHMe}$ ), 5.09 (s, $\left.1 \mathrm{H}, \gamma-H\right), 7.12-7.15(\mathrm{~m}, 6 \mathrm{H}, \mathrm{Ar}-H), 7.54$ (s, 1H, CH=N); EI-MS: $m / z(\%) 545(38) M^{+}, 544(100)(M-\mathrm{H})^{+}$; Elemental analysis for $\mathrm{C}_{34} \mathrm{H}_{52} \mathrm{AlN}_{3} \mathrm{O}$ (545.78): Calcd. C, 74.82; H, 9.60; N, 7.70; Found C, 75.03; H, 9.51; N, 7.83 $\%$.

\subsection{6. $\mathrm{LAl}(\mathrm{OCH}=\mathrm{N}-t \mathrm{Bu})_{2}\left(\mathrm{~L}=\mathrm{HC}(\mathrm{CMeNAr})_{2}, \mathrm{Ar}=2,6-i \mathrm{Pr}_{2} \mathrm{C}_{6} \mathrm{H}_{3}\right)(7)$}

Tert-butylisocyanate $(0.30 \mathrm{~mL}, 2.90 \mathrm{mmol})$ was added by syringe to $\mathrm{LAlH}_{2}(0.620 \mathrm{~g}, 1.39$ mmol) (5) in toluene $(20 \mathrm{~mL})$. The solution was refluxed for $2.5 \mathrm{~h}$. After removal of all the volatiles the residue was recrystallised from pentane. The concentrated resulting solution was kept at $0{ }^{\circ} \mathrm{C}$ to afford colourless crystals. Yield: $80 \%(0.72 \mathrm{~g})$.

M.p.: $175-176{ }^{\circ} \mathrm{C} ;{ }^{1} \mathrm{H}$ NMR (300.13 MHz, $\left.\mathrm{C}_{6} \mathrm{D}_{6}\right): \delta 0.98$ (s, $\left.18 \mathrm{H}, t B u\right), 1.40(\mathrm{~d}, 12 \mathrm{H}$, $\left.{ }^{3} J_{\mathrm{H}-\mathrm{H}}=6.8 \mathrm{~Hz}, \mathrm{CH}\left(\mathrm{CH}_{3}\right)_{2}\right), 1.54\left(\mathrm{~s}, 6 \mathrm{H},\left(\mathrm{CH}_{3}\right)\right), 1.66\left(\mathrm{~d}, 12 \mathrm{H},{ }^{3} J_{\mathrm{H}-\mathrm{H}}=6.8 \mathrm{~Hz}, \mathrm{CH}\left(\mathrm{CH}_{3}\right)_{2}\right), 3.42$ (sept, 4H, CHMe 2 ), 5.13 (s, 1H, $\gamma-H), 7.12-7.15$ (m, 6H, Ar- $H$ ), 7.45 (s, 2H, CH=N); EI-MS: $m / z(\%) 644(2)\left[M^{+}\right], 587(16)[M-t \mathrm{Bu}]^{+}, 544(100)(M-\mathrm{HOCH}=\mathrm{N} t \mathrm{Bu})^{+} ;$Elemental analysis for $\mathrm{C}_{39} \mathrm{H}_{61} \mathrm{AlN}_{4} \mathrm{O}_{2}$ (644.91): Calcd. C, 72.63; H, 9.53; N, 8.69; Found C, 72.53; H, $9.84 ; \mathrm{N}, 8.27 \%$. 


\subsection{7. $\mathrm{LAl}(\mathrm{OH}) \mathrm{OAIL}(\mathrm{OCH}=\mathrm{N}-t \mathrm{Bu})\left(\mathrm{L}=\mathrm{HC}(\mathrm{CMeNAr})_{2}, \mathrm{Ar}=2,6-i \mathrm{Pr}_{2} \mathrm{C}_{6} \mathrm{H}_{3}\right)(8)$}

Method 1: The procedure is the same as that for the preparation of $\mathbf{6}$, except that the ratio of the reagents is $1: 2$, and the resulting concentrated pentane solution reacted with water when it was stored at $0{ }^{\circ} \mathrm{C}$ to obtain 8 in $18 \%$ yield. Method 2: A solution of $\mathrm{H}_{2} \mathrm{O}(0.07 \mathrm{~mL}, 3.9$ $\mathrm{mmol})$ in THF $(70 \mathrm{~mL})$ was added dropwise to the solution of $\mathrm{LAlH}_{2}(\mathbf{5})(0.87 \mathrm{~g}, 1.95 \mathrm{mmol})$ and $6(1.06 \mathrm{~g}, 1.95 \mathrm{mmol})$ in $\mathrm{THF}(20 \mathrm{~mL})$ at $-30{ }^{\circ} \mathrm{C}$. The resulting solution was warmed slowly to room temperature and stirred for additional $12 \mathrm{~h}$. All volatiles were removed under reduced pressure. The residue was extracted with pentane $(8 \mathrm{~mL})$. After filtration the solution was concentrated and kept at $0{ }^{\circ} \mathrm{C}$. Colourless crystals were obtained. Yield: $20 \%(0.40 \mathrm{~g})$.

M.p.: $185{ }^{\circ} \mathrm{C} \mathrm{dec}$; IR (nujol): $\tilde{v}=3458 \mathrm{~cm}^{-1}$ (br, O-H stretch); ${ }^{1} \mathrm{H}$ NMR $(300.13 \mathrm{MHz}$, $\left.\mathrm{C}_{6} \mathrm{D}_{6}\right): \delta-0.30(\mathrm{~s}, 1 \mathrm{H}, \mathrm{OH}), 0.73\left(\mathrm{~d}, 6 \mathrm{H}, J=6.7 \mathrm{~Hz}, \mathrm{CH}\left(\mathrm{CH}_{3}\right)_{2}\right), 0.82(\mathrm{~d}, 6 \mathrm{H}, J=6.6 \mathrm{~Hz}$, $\left.\mathrm{CH}\left(\mathrm{CH}_{3}\right)_{2}\right), 0.87\left(\mathrm{~s}, 3 \mathrm{H}, t \mathrm{C}_{4} H_{9}\right), 1.09\left(\mathrm{~s}, 6 \mathrm{H}, t \mathrm{C}_{4} H_{9}\right), 1.14\left(\mathrm{~d}, 15 \mathrm{H}, J=6.9 \mathrm{~Hz}, \mathrm{CH}\left(\mathrm{CH}_{3}\right)_{2}\right)$, $1.20\left(\mathrm{~d}, 3 \mathrm{H}, J=6.9 \mathrm{~Hz}, \mathrm{CH}\left(\mathrm{CH}_{3}\right)_{2}\right), 1.35\left(\mathrm{~d}, 12 \mathrm{H}, J=6.8 \mathrm{~Hz}, \mathrm{CH}\left(\mathrm{CH}_{3}\right)_{2}\right), 1.41(\mathrm{~d}, 6 \mathrm{H}, J=$ 6.7 Hz, $\left.\mathrm{CH}\left(\mathrm{CH}_{3}\right)_{2}\right), 1.45$ (s, $\left.3 \mathrm{H},\left(\mathrm{CH}_{3}\right)\right), 1.50$ (s, $\left.3 \mathrm{H},\left(\mathrm{CH}_{3}\right)\right), 1.54\left(\mathrm{~s}, 3 \mathrm{H},\left(\mathrm{CH}_{3}\right)\right), 1.57$ (s, 3 $\mathrm{H},\left(\mathrm{CH}_{3}\right)$ ), 3.12 (sept, $2 \mathrm{H}, J=6.6 \mathrm{~Hz}, \mathrm{CHMe}$ ), 3.24 (sept, $2 \mathrm{H}, J=6.8 \mathrm{~Hz}, \mathrm{CHMe}$ ), 3.46 (sept. $1 \mathrm{H}, J=6.8 \mathrm{~Hz}, \mathrm{CHMe}$ ), 3.57 (sept, $1 \mathrm{H}, J=6.7 \mathrm{~Hz}, \mathrm{CHMe}$ ), 3.73 (sept, $2 \mathrm{H}, J=6.8$ $\mathrm{Hz}, \mathrm{CHMe}$ ), 4.86 (s, $1 \mathrm{H}, \gamma-H), 4.91(\mathrm{~s}, 1 \mathrm{H}, \gamma-H), 7.25-7.00(\mathrm{~m}, 12 \mathrm{H}, \mathrm{Ar}-H), 7.81$ (s, $1 \mathrm{H}$, $\mathrm{CH} H=\mathrm{N})$; EI-MS: $m / z(\%) 1021(40) M^{+}, 604(100)(M-\mathrm{L})^{+}$; Elemental analysis for $\mathrm{C}_{68} \mathrm{H}_{104} \mathrm{Al}_{2} \mathrm{~N}_{5} \mathrm{O}_{3}(1093.52)\left(8 \cdot \mathrm{C}_{5} \mathrm{H}_{12}\right)$ : Calcd. C, 74.69; H, 9.59; N, 6.40; Found C, 73.81; H, $9.58 ; \mathrm{N}, 6.31 \%$.

4.4.8. $\left(\mathrm{RCH}_{2} \mathrm{NAlH}\right)_{7}(\mathrm{R}=1$-adamantyl $)(9)$ 
$\mathrm{AlH}_{3} \cdot \mathrm{NMe}_{3}(6.2 \mathrm{~mL}, 0.8 \mathrm{M}$ solution in toluene, $4.96 \mathrm{mmol})$ was added under stirring to a solution of $\mathrm{RC} \equiv \mathrm{N}(0.53 \mathrm{~g}, 3.29 \mathrm{mmol})$ in toluene $(15 \mathrm{~mL})$ at $-78{ }^{\circ} \mathrm{C}$. The mixture was kept at this temperature for $1 \mathrm{~h}$ before it was slowly warmed to room temperature, and then refluxed until gas evolution ceased. After cooling the solution to room temperature it was filtered to remove the insoluble precipitate. Finally the volatiles were removed in vacuo from the filtrate to yield product 9. Single crystals suitable for X-ray diffraction analysis were obtained from toluene at room temperature. Yield: $51 \%(0.32 \mathrm{~g})$.

M.p.: > $340{ }^{\circ} \mathrm{C}$; IR (nujol): 1916, 1896, 1867, $1851 \mathrm{~cm}^{-1}$ (Al-H strech); ${ }^{1} \mathrm{H}$ NMR $(300.13$ $\left.\mathrm{MHz}, \mathrm{CDCl}_{3}\right): \delta 1.56,1.66,1.87,1.99(105 \mathrm{H}, 1$-adamantyl $), 2.76,2.79,3.05\left(14 \mathrm{H}, \mathrm{CH}_{2}\right)$; EI-MS (70 eV): $m / z(\%) 1337(11)(M-\mathrm{H})^{+}, 1203(100)(M-1 \text {-adamantyl })^{+}$; Elemental analysis for $\mathrm{C}_{84} \mathrm{H}_{134} \mathrm{Al}_{7} \mathrm{~N}_{7}(1430.88)\left(9 \cdot \mathrm{C}_{7} \mathrm{H}_{8}\right)$ : Calcd. C, 70.51; H, 9.44; N, 6.85; Found $\mathrm{C}$, $68.87 ; \mathrm{H}, 9.24 ; \mathrm{N}, 6.66 \%$.

\subsection{9. $\left[\left(\mathrm{RCH}_{2} \mathrm{NAl}\right)_{7} \mathrm{H}_{4.74} \mathrm{~F}_{2.26}\right](\mathrm{R}=1$-adamantyl $)(10)$}

To a mixture of $9(0.50 \mathrm{~g}, 0.37 \mathrm{mmol})$ and $\mathrm{Me}_{3} \mathrm{SnF}(0.47 \mathrm{~g}, 2.60 \mathrm{mmol})$ toluene $(30 \mathrm{~mL})$ was added at room temperature. The resulting solution was refluxed for $2 \mathrm{~h}$ and then filtered. The solvent from the filtrate was removed in vacuo to yield compound 10. Single crystals suitable for X-ray diffraction analysis were obtained from toluene at room temperature. Yield: $47 \%(0.24 \mathrm{~g})$

M.p.: $190{ }^{\circ} \mathrm{C} \mathrm{dec}$; IR (nujol): $1895 \mathrm{~cm}^{-1}$ (Al-H strech); ${ }^{1} \mathrm{H}$ NMR $\left(300.13 \mathrm{MHz}, \mathrm{CDCl}_{3}\right.$ ): $\delta 1.55,1.66,1.68,1.85,1.88,1.99$ (105 H, 1-adamantyl), 2.76, 2.78, 2.80, 3.02, 3.03, 3.08 $\left(14 \mathrm{H}, \mathrm{CH}_{2}\right) ;{ }^{19} \mathrm{~F}$ NMR $\left(188.28 \mathrm{MHz}, \mathrm{CDCl}_{3}\right):-163.89,-162.77,-162.15$; EI-MS (70 eV): The 
mass spectrum only shows $\mathrm{CH}$ fragments; Elemental analysis for $\mathrm{C}_{84} \mathrm{H}_{131.74} \mathrm{Al}_{7} \mathrm{~F}_{2.26} \mathrm{~N}_{7}(1466.73)$ (10. $\left.\mathrm{C}_{7} \mathrm{H}_{8}\right)$ : Calcd. C, 68.56; H, 9.23; N, 6.66; F, 2.92; Found C, 67.20; H, 9.02; N, 6.30; F, $2.81 \%$.

\subsubsection{0. $\left(t \mathrm{BuNCH} \mathrm{HIF}_{4}(11)\right.$}

To a mixture of $\left(t-\mathrm{BuNCH}_{2} \mathrm{AlH}\right)_{4}(0.467 \mathrm{~g}, 1 \mathrm{mmol})$ and $\mathrm{Me}_{3} \mathrm{SnF}(0.779 \mathrm{~g}, 4.3 \mathrm{mmol})$ $\mathrm{CH}_{2} \mathrm{Cl}_{2}(50 \mathrm{~mL})$ was added at room temperature. The resulting solution was stirred at room temperature for $3 \mathrm{~d}$ and a suspension was obtained. The suspension was filtered and the volatiles were removed in vacuo from the filtrate. The resulting residue was dissolved in toluene to afford colourless crystals at $0{ }^{\circ} \mathrm{C}$. Yield: $67 \%(0.35 \mathrm{~g})$.

M.p.: $288-289{ }^{\circ} \mathrm{C} ;{ }^{1} \mathrm{H}$ NMR (300.13 MHz, $\left.\mathrm{CDCl}_{3}\right): \delta 1.32,1.50$ (br, $36 \mathrm{H}, t \mathrm{C}_{4} H_{9}$ ), $1.74\left(\mathrm{~d}, 4 \mathrm{H}, J=13.0 \mathrm{~Hz}, C_{2}\right), 1.93\left(\mathrm{~d}, 4 \mathrm{H}, J=13.1 \mathrm{~Hz}, C_{2}\right) ;{ }^{19} \mathrm{~F}$ NMR $(188.28 \mathrm{MHz}$, $\left.\mathrm{CDCl}_{3}\right):-155.74 ;$ EI-MS $(70 \mathrm{eV}): m / z(\%) 509(4)(M-\mathrm{Me})^{+}, 467(100)\left([M-t \mathrm{Bu}]^{+}\right.$; Elemental analysis for $\mathrm{C}_{20} \mathrm{H}_{44} \mathrm{Al}_{4} \mathrm{~F}_{4} \mathrm{~N}_{4}$ (524.51): Calcd. C, 45.80; H, 8.46; N, 10.68; F, 14.49; Found C, 45.96; H, 8.40; N, 10.57; F, $14.11 \%$.

\subsubsection{1. $\left[\mathrm{HC}(\mathrm{CPhNAr})_{2}\right] \mathrm{AlMe}_{2}\left(\mathrm{Ar}=2,6-i \mathrm{Pr}_{2} \mathrm{C}_{6} \mathrm{H}_{3}\right)(13)$}

$\mathrm{AlMe}_{3}(1.5 \mathrm{~mL}, 2.0 \mathrm{M}$ solution in toluene, $3 \mathrm{mmol})$ was added under stirring to a solution of $\left[\mathrm{HC}(\mathrm{CPhNAr})_{2}\right] \mathrm{H}(1.62 \mathrm{~g}, 3 \mathrm{mmol})$ in toluene $(30 \mathrm{ml})$ at $0{ }^{\circ} \mathrm{C}$. The mixture was slowly warmed to room temperature and then refluxed for $1 \mathrm{~h}$. After cooling to room temperature the resulting solution was concentrated to ca. $8 \mathrm{~mL}$ and kept at $-20{ }^{\circ} \mathrm{C}$ to afford yellow-green crystals. Yield: $60 \%(1.07 \mathrm{~g})$. 
M.p.: $235-237{ }^{\circ} \mathrm{C} ;{ }^{1} \mathrm{H}$ NMR (500.13 MHz, $\left.\mathrm{CDCl}_{3}\right): \delta-0.76\left(\mathrm{~s}, 6 \mathrm{H}, \mathrm{Al}-\left(\mathrm{CH}_{3}\right)\right), 0.86$ (d, $\left.12 \mathrm{H}, J=6.7 \mathrm{~Hz}, \mathrm{CH}\left(\mathrm{CH}_{3}\right)_{2}\right), 1.22\left(\mathrm{~d}, 12 \mathrm{H}, J=6.7 \mathrm{~Hz}, \mathrm{CH}\left(\mathrm{CH}_{3}\right)_{2}\right), 3.31$ (sept, $4 \mathrm{H}, J=6.7$ $\mathrm{Hz}, \mathrm{CHMe}$ ), 5.59 (s, $1 \mathrm{H}, \gamma-H), 7.03-7.25$ (m, $16 \mathrm{H}, \mathrm{Ar}-H)$; EI-MS (70 eV): $/ \mathrm{z}(\%) 583$ (100) $(M-\mathrm{Me})^{+}$; Elemental analysis for $\mathrm{C}_{41} \mathrm{H}_{51} \mathrm{AlN}_{2}$ (598.84): Calcd. C, 82.23; H, 8.58; N, 4.68; Found: C, 82.50; H, 8.40; N, $4.82 \%$.

\subsubsection{2. $\left[\mathrm{HC}(\mathrm{CMeNAr})_{2}\right]_{2} \mathrm{Al}_{2} \mathrm{P}_{4}\left(\mathrm{Ar}=2,6-i \mathrm{Pr}_{2} \mathrm{C}_{6} \mathrm{H}_{3}\right)(14)$}

Toluene $(30 \mathrm{~mL})$ was added to a mixture of $12(0.445 \mathrm{~g}, 1 \mathrm{mmol})$ and $\mathrm{P}_{4}(0.062 \mathrm{~g}, 0.5$ mmol). The resulting solution was stirred at room temperature for one week. After removal of the solvent the residue was recrystallised from a mixture of hexane and pentane at room temperature to afford red crystals. Yield: $79 \%(0.40 \mathrm{~g})$.

M.p.: $145^{\circ} \mathrm{C} \mathrm{dec} ;{ }^{1} \mathrm{H}$ NMR $\left(300.13 \mathrm{MHz}, \mathrm{C}_{6} \mathrm{D}_{6}\right): \delta 1.13\left(\mathrm{~d}, 24 \mathrm{H}, J=6.8 \mathrm{~Hz}, \mathrm{CH}\left(\mathrm{CH}_{3}\right)_{2}\right)$ $1.15\left(\mathrm{~d}, 24 \mathrm{H}, J=6.8 \mathrm{~Hz}, \mathrm{CH}\left(\mathrm{CH}_{3}\right)_{2}\right), 1.70$ (s, $\left.12 \mathrm{H},\left(\mathrm{CH}_{3}\right)\right), 3.61$ (sept, $8 \mathrm{H}, J=6.8 \mathrm{~Hz}$, $\left.\mathrm{CHMe}_{2}\right), 5.03(\mathrm{~s}, 2 \mathrm{H}, \gamma-H), 7.15-7.02(\mathrm{~m}, 12 \mathrm{H}, \mathrm{Ar}-H) ;{ }^{13} \mathrm{C}$ NMR $\left(125.77 \mathrm{MHz}, \mathrm{C}_{6} \mathrm{D}_{6}\right): \delta$ $169.97(C \mathrm{~N}), 143.94,142.07,124.14(\mathrm{Ar}), 97.79(\gamma-C), 29.26\left(C \mathrm{HMe}_{2}\right), 25.43\left(\mathrm{CH}\left(\mathrm{CH}_{3}\right)_{2}\right)$, $24.57\left(\mathrm{CH}\left(\mathrm{CH}_{3}\right)_{2}\right), 23.86\left(\left(\mathrm{CH}_{3}\right)\right) ;{ }^{27} \mathrm{Al} \mathrm{NMR}\left(600 \mathrm{MHz}, 26 \mathrm{KHz}, \mathrm{MAS}, \mathrm{AlCl}_{3}\right): \delta=50-120$ ppm; ${ }^{31} \mathrm{P}$ NMR (121.5 MHz, $\left.\mathrm{C}_{6} \mathrm{D}_{6}\right): \delta 78.6 \mathrm{ppm}$; EI-MS: $m / z(\%) 1012(30) M^{+}, 429(100)$ $(\mathrm{LAl}-\mathrm{Me})^{+}$; Elemental analysis for $\mathrm{C}_{63} \mathrm{H}_{94} \mathrm{Al}_{2} \mathrm{~N}_{4} \mathrm{P}_{4}(1085.26)\left(\mathbf{1 4} \cdot \mathrm{C}_{5} \mathrm{H}_{12}\right)$ : Calcd. C, 69.72; H, 8.73; N, 5.16; Found C, 69.88; H, 8.12; N, $5.76 \%$.

\subsubsection{3. $\mathrm{LAl}\left(\mu-\mathrm{S}_{3}\right)_{2} \mathrm{AlL}\left(\mathrm{L}=\mathrm{HC}(\mathrm{CMeNAr})_{2}, \mathrm{Ar}=2,6-i \mathrm{Pr}_{2} \mathrm{C}_{6} \mathrm{H}_{3}\right)(15)$}

Toluene $(30 \mathrm{~mL})$ was added to a mixture of $12(0.580 \mathrm{~g}, 1.3 \mathrm{mmol})$ and $\mathrm{S}_{8}(0.125 \mathrm{~g}, 3.9$ 
mmol) at $-78{ }^{\circ} \mathrm{C}$. The resulting suspension was stirred at this temperature for $2 \mathrm{~h}$ and slowly warmed to room temperature. The mixture was stirred for additional $15 \mathrm{~h}$. After removal of the precipitate by filtration, the concentrated solution was kept at room temperature for 3 days to afford pale yellow crystals of 2 . Yield: $22 \%(0.150 \mathrm{~g})$.

M.p.: $185^{\circ} \mathrm{C} \mathrm{dec} ;{ }^{1} \mathrm{H}$ NMR (500.13 MHz, $\left.\mathrm{C}_{6} \mathrm{D}_{6}\right): \delta 1.00\left(\mathrm{~d}, 24 \mathrm{H}, J=6.8 \mathrm{~Hz}, \mathrm{CH}\left(\mathrm{CH}_{3}\right)_{2}\right)$, $1.37\left(\mathrm{~d}, 24 \mathrm{H}, J=6.8 \mathrm{~Hz}, \mathrm{CH}\left(\mathrm{CH}_{3}\right)_{2}\right), 1.50\left(\mathrm{~s}, 12 \mathrm{H},\left(\mathrm{CH}_{3}\right)\right), 3.30$ (sept, $8 \mathrm{H}, J=6.8 \mathrm{~Hz}$, $\left.\mathrm{CHMe}_{2}\right), 4.72(\mathrm{~s}, 2 \mathrm{H}, \gamma-H), 7.20-6.90(\mathrm{~m}, 12 \mathrm{H}, \mathrm{Ar}-H) ;{ }^{13} \mathrm{C} \mathrm{NMR}\left(125.77 \mathrm{MHz}, \mathrm{C}_{6} \mathrm{D}_{6}\right): \delta$ $23.55\left(\left(\mathrm{CH}_{3}\right)\right), 23.93\left(\mathrm{CH}\left(\mathrm{CH}_{3}\right)_{2}\right), 25.45\left(\mathrm{CH}\left(\mathrm{CH}_{3}\right)_{2}\right), 28.92\left(C \mathrm{HMe}_{2}\right), 97.74(\gamma-C), 145.74$, 143.69, 128.20, $123.83(A r), 171.78(C N)$; EI-MS: $m / z(\%) 508(100)\left(M-\mathrm{LAlS}_{4}\right)^{+}, 540(38)$ $\left(M-\mathrm{LAlS}_{3}\right)^{+}, 572(15)\left(M-\mathrm{LAlS}_{2}\right)^{+}$; Elemental analysis for $\mathrm{C}_{58} \mathrm{H}_{82} \mathrm{Al}_{2} \mathrm{~N}_{4} \mathrm{~S}_{6}(1081.66)$ $\left(\mathbf{1 5} \cdot 2 \mathrm{C}_{7} \mathrm{H}_{8}\right)$ : Calcd. C, 64.40; H, 7.64; N, 5.18; Found C, 64.65; H, 7.88; N, $4.76 \%$. 


\section{Handling and Disposal of Solvents and Residual Waste}

1. The recovered solvents were distilled or condensed into cold-traps under vacuum and collected in halogen-free or halogen-containing solvent containers, and stored for disposal.

2. Used NMR solvents were classified into halogen-free and halogen-containing solvents and were disposed as heavy metal wastes and halogen-containing wastes, respectively.

3. The heavy metal residues were dissolved in nitric acid and after neutralisation stored in the containers for heavy metal wastes.

4. Drying agents such as $\mathrm{KOH}, \mathrm{CaCl}_{2}$, and $\mathrm{P}_{4} \mathrm{O}_{10}$ were hydrolyzed and disposed as acid or base wastes.

5. Whenever possible, sodium metal used for drying solvents was collected for recycling. ${ }^{87}$ The non-reusable sodium metal was carefully hydrolysed in cold ethanol and poured into the base-bath used for cleaning glassware.

6. Ethanol and acetone used for cold-baths were subsequently used for cleaning glassware.

7. The acid-bath used for cleaning glassware was neutralized with $\mathrm{Na}_{2} \mathrm{CO}_{3}$ and the resulting $\mathrm{NaCl}$ solution was washed-off in the communal water drainage.

8. The residue of the base-bath used for glassware cleaning was poured into the container for base wastes. 
Amounts of various types of disposable wastes generated during the work:

Metal containing wastes

Halogen-containing solvent wastes

Halogen-free solvent wastes

Acid wastes

Base wastes
$10 \mathrm{~L}$

$5 \mathrm{~L}$

$35 \mathrm{~L}$

$10 \mathrm{~L}$

$20 \mathrm{~L}$ 


\section{Crystal Data and Refinement Details}

Table CD1. Crystal data and structure refinement for $2 \cdot \mathrm{C}_{7} \mathrm{H}_{8}$.

\begin{tabular}{|c|c|}
\hline Empirical formula & $\mathrm{C}_{34} \mathrm{H}_{51} \mathrm{AlN}_{2} \mathrm{O}$ \\
\hline Formula weight & 530.75 \\
\hline Temperature & $100(2) \mathrm{K}$ \\
\hline Wavelength & $1.54178 \AA$ \\
\hline Crystal system & Monoclinic \\
\hline Space group & $P 2_{1} / c$ \\
\hline \multirow[t]{3}{*}{ Unit cell dimensions } & $a=9.100(1) \AA$ \\
\hline & $b=9.632(1) \AA, \beta=96.65(1)^{\circ}$ \\
\hline & $c=36.703(1) \AA$ \\
\hline Volume & $3195(1) \AA^{3}$ \\
\hline$Z$ & 4 \\
\hline Calculated density & $1.103 \mathrm{Mg} / \mathrm{m}^{3}$ \\
\hline Absorption coefficient & $0.746 \mathrm{~mm}^{-1}$ \\
\hline$F(000)$ & 1160 \\
\hline$\theta$ range for data collection & $2.42-58.94^{\circ}$ \\
\hline Index ranges & $-10 \leq h \leq 10,-10 \leq k \leq 10,-40 \leq l \leq 40$ \\
\hline Reflections collected & 13836 \\
\hline Independent reflections & $4447[R($ int $)=0.0327]$ \\
\hline Refinement method & Full-matrix least-squares on $F^{2}$ \\
\hline Data / restraints / parameters & 4447 / 0 / 361 \\
\hline Goodness-of-fit on $F^{2}$ & 1.045 \\
\hline Final $R$ indices $[I>2 \sigma(I)]$ & $R 1=0.0338, w R 2=0.0845$ \\
\hline$R$ indices (all data) & $R 1=0.0413, w R 2=0.0886$ \\
\hline Largest difference peak and hole & 0.169 and $-0.243 \mathrm{e} \cdot \AA^{-3}$ \\
\hline
\end{tabular}


Table CD2. Crystal data and structure refinement for $3 \cdot 2 \mathrm{C}_{7} \mathrm{H}_{8}$.

Empirical formula

Formula weight

Temperature

Wavelength

Crystal system

Space group

Unit cell dimensions

Volume

Z

Calculated density

Absorption coefficient

$F(000)$

$\theta$ range for data collection

Index ranges

Reflections collected

Independent reflections

Refinement method

Data / restraints / parameters

Goodness-of-fit on $F^{2}$

Final $R$ indices $[I>2 \sigma(I)]$

$R$ indices (all data)

Largest difference peak and hole
$\mathrm{C}_{62} \mathrm{H}_{84} \mathrm{Al}_{2} \mathrm{~N}_{2} \mathrm{O}_{2} \mathrm{~S}_{2}$

1007.39

100(2)

$1.54178 \AA$

Triclinic

$P \overline{1}$

$a=12.149(1) \AA, \alpha=108.94(1)^{\circ}$

$b=12.345(1) \AA, \beta=118.62(1)^{\circ}$

$c=12.554(1) \AA, \gamma=97.75(1)^{\circ}$

1465(1) $\AA^{3}$

1

$1.142 \mathrm{Mg} / \mathrm{m}^{3}$

$1.431 \mathrm{~mm}^{-1}$

544

$4.04-58.97^{\circ}$

$-13 \leq h \leq 13,-13 \leq k \leq 13,-13 \leq l \leq 13$

11561

$4107[R(\mathrm{int})=0.0299]$

Full-matrix least-squares on $F^{2}$

4107 / 249 / 394

1.047

$R 1=0.0324, w R 2=0.0859$

$R 1=0.0369, w R 2=0.0891$

0.200 and $-0.232 \mathrm{e} \cdot \AA^{-3}$ 


\section{Table CD3. Crystal data and structure refinement for $4 \cdot 2 C_{7} H_{8}$.}

Empirical formula

Formula weight

Temperature

Wavelength

Crystal system

Space group

Unit cell dimensions

Volume

$Z$

Calculated density

Absorption coefficient

$F(000)$

$\theta$ range for data collection

Index ranges

Reflections collected

Independent reflections

Refinement method

Data / restraints / parameters

Goodness-of-fit on $F^{2}$

Final $R$ indices $[I>2 \sigma(I)]$

$R$ indices (all data)

Largest difference peak and hole
$\mathrm{C}_{62} \mathrm{H}_{82} \mathrm{Al}_{2} \mathrm{~N}_{2} \mathrm{O}_{2} \mathrm{Se}_{2}$

1101.19

133(2) K

$0.71073 \AA$

Triclinic

$P \overline{1}$

$a=10.0480(4) \AA, \alpha=77.061(3)^{\circ}$

$b=12.4855(5) \AA, \beta=68.039(3)^{\circ}$

$c=13.1473(6) \AA, \gamma=89.284(3)^{\circ}$

1486.23(11) $\AA^{3}$

1

$1.230 \mathrm{Mg} / \mathrm{m}^{3}$

$1.315 \mathrm{~mm}^{-1}$

580

$1.68-24.82^{\circ}$

$-11 \leq h \leq 11,-14 \leq k \leq 14,-15 \leq l \leq 15$

50725

$5105[R($ int $)=0.0437]$

Full-matrix least-squares on $F^{2}$

$5105 / 0 / 292$

1.020

$R 1=0.0345, w R 2=0.0878$

$R 1=0.0367, w R 2=0.0891$

0.920 and $-0.633 \mathrm{e} \cdot \AA^{-3}$ 
Table CD4. Crystal data and structure refinement for $8 \cdot \mathrm{C}_{5} \mathrm{H}_{12}$

Empirical formula

Formula weight

Temperature

Wavelength

Crystal system

Space group

Unit cell dimensions

Volume

Z

Calculated density

Absorption coefficient

$F(000)$

$\theta$ range for data collection

Index ranges

Reflections collected

Independent reflections

Refinement method

Data / restraints / parameters

Goodness-of-fit on $F^{2}$

Final $R$ indices $[I>2 \sigma(I)]$

$R$ indices (all data)

Largest difference peak and hole
$\mathrm{C}_{68} \mathrm{H}_{104} \mathrm{Al}_{2} \mathrm{~N}_{5} \mathrm{O}_{3}$

1093.52

133(2) K

$0.71073 \AA$

Monoclinic

$P 2{ }_{1} / c$

$a=14.128(3) \AA$

$b=21.500(4) \AA, \beta=98.01(3)^{\circ}$

$c=22.083(4) \AA$

6642(2) $\AA^{3}$

4

$1.093 \mathrm{Mg} / \mathrm{m}^{3}$

$0.090 \mathrm{~mm}^{-1}$

2388

$1.74-24.87^{\circ}$

$-16 \leq h \leq 16,-23 \leq k \leq 25,-26 \leq l \leq 26$

39741

$11408[R($ int $)=0.1377]$

Full-matrix least-squares on $F^{2}$

11408 / 2 / 770

0.722

$R 1=0.0484, w R 2=0.0935$

$R 1=0.1009, w R 2=0.1035$

0.254 and $-0.252 \mathrm{e} \cdot \AA^{-3}$ 
Table CD5. Crystal data and structure refinement for $9 \cdot \mathrm{C}_{7} \mathrm{H}_{8}$.

Empirical formula

Formula weight

Temperature

Wavelength

Crystal system

Space group

Unit cell dimensions

Volume

Z

Calculated density

Absorption coefficient

$F(000)$

$\theta$ range for data collection

Index ranges

Reflections collected

Independent reflections

Refinement method

Data / restraints / parameters

Goodness-of-fit on $F^{2}$

Final $R$ indices $[I>2 \sigma(I)]$

$R$ indices (all data)

Largest difference peak and hole
$\mathrm{C}_{84} \mathrm{H}_{134} \mathrm{Al}_{7} \mathrm{~N}_{7}$

1430.88

133(2) K

$0.71073 \AA$

Triclinic

$P \overline{1}$

$a=13.254(3) \AA, \alpha=82.71(3)^{\circ}$

$b=15.305(3) \AA, \beta=75.80(3)^{\circ}$

$c=20.996(4) \AA, \gamma=75.50(3)^{\circ}$

3987.7(14) $\AA^{3}$

2

$1.186 \mathrm{Mg} / \mathrm{m}^{3}$

$0.140 \mathrm{~mm}^{-1}$

1542

$1.63-24.84^{\circ}$

$-15 \leq h \leq 15,-16 \leq k \leq 18,-24 \leq l \leq 24$

28395

$12367[R(\mathrm{int})=0.0524]$

Full-matrix least-squares on $F^{2}$

12367 / 0 / 852

0.939

$R 1=0.0441, w R 2=0.1194$

$R 1=0.0582, w R 2=0.1241$

0.716 and $-0.371 \mathrm{e} \cdot \AA^{-3}$ 
Table CD6. Crystal data and structure refinement for $10 \cdot \mathrm{C}_{7} \mathbf{H}_{8}$.

Empirical formula

Formula weight

Temperature

Wavelength

Crystal system

Space group

Unit cell dimensions

$\mathrm{V}$

Volume

Z

Calculated density

Absorption coefficient

$F(000)$

$\theta$ range for data collection

Index ranges

Reflections collected

Independent reflections

Refinement method

Data / restraints / parameters

Goodness-of-fit on $F^{2}$

Final $R$ indices $[I>2 \sigma(I)]$

$R$ indices (all data)

Largest difference peak and hole
$\mathrm{C}_{84} \mathrm{H}_{127} \mathrm{Al}_{7} \mathrm{~F}_{2.26} \mathrm{~N}_{7}$

1466.73

133(2) K

$0.71073 \AA$

Triclinic

$P \overline{1}$

$a=13.254(3) \AA, \alpha=82.75(3)^{\circ}$

$b=15.216(3) \AA, \beta=75.89(3)^{\circ}$

$c=21.059(4) \AA, \gamma=75.38(3)^{\circ}$

3976.2(14) $\AA^{3}$

2

$1.225 \mathrm{Mg} / \mathrm{m}^{3}$

$0.146 \mathrm{~mm}^{-1}$

1583

$1.39-24.90^{\circ}$

$-15 \leq h \leq 15,-18 \leq k \leq 17,-24 \leq l \leq 24$

62662

$13754[R($ int $)=0.0858]$

Full-matrix least-squares on $F^{2}$

13754 / 0 / 879

0.829

$R 1=0.0397, w R 2=0.0954$

$R 1=0.0586, w R 2=0.0993$

0.689 and $-0.353 \mathrm{e} \cdot \AA^{-3}$ 
Table CD7. Crystal data and structure refinement for $11 \cdot \mathrm{C}_{7} \mathrm{H}_{8}$.

Empirical formula

Formula weight

Temperature

Wavelength

Crystal system

Space group

Unit cell dimensions

Volume

Z

Calculated density

Absorption coefficient

$F(000)$

$\theta$ range for data collection

Index ranges

Reflections collected

Independent reflections

Refinement method

Data / restraints / parameters

Goodness-of-fit on $F^{2}$

Final $R$ indices $[I>2 \sigma(I)]$

$R$ indices (all data)

Largest difference peak and hole
$\mathrm{C}_{20} \mathrm{H}_{44} \mathrm{Al}_{4} \mathrm{~F}_{4} \mathrm{~N}_{4}$

524.51

200(2) K

$0.71073 \AA$

Monoclinic

$P 2{ }_{1} / n$

$a=11.5158(16) \AA$

$b=13.447(2) \AA, \beta=91.094(14)^{\circ}$

$c=17.086(3) \AA$

2645.3(8) $\AA^{3}$

4

$1.317 \mathrm{Mg} / \mathrm{m}^{3}$

$0.220 \mathrm{~mm}^{-1}$

1120

$3.51-25.03^{\circ}$

$-13 \leq h \leq 13,-16 \leq k \leq 16,-20 \leq l \leq 20$

9300

$4650[R($ int $)=0.0573]$

Full-matrix least-squares on $F^{2}$

4650 / 0 / 301

1.062

$R 1=0.0383, w R 2=0.1019$

$R 1=0.0403, w R 2=0.1043$

0.522 and $-0.330 \mathrm{e} \cdot \AA^{-3}$ 
Table CD8. Crystal data and structure refinement for 13.

Empirical formula

Formula weight

Temperature

Wavelength

Crystal system

Space group

Unit cell dimensions

Volume

Z

Calculated density

Absorption coefficient

$F(000)$

$\theta$ range for data collection

Index ranges

Reflections collected

Independent reflections

Refinement method

Data / restraints / parameters

Goodness-of-fit on $F^{2}$

Final $R$ indices $[I>2 \sigma(I)]$

$R$ indices (all data)

Largest difference peak and hole
$\mathrm{C}_{41} \mathrm{H}_{51} \mathrm{AlN}_{2}$

598.82

200(2)

$0.71073 \AA$

Monoclinic

$P 2 / n$

$a=18.100(4) \AA$

$b=12.568(3) \AA, \beta=100.14(3)^{\circ}$

$c=31.973(6) \AA$

$7160(2) \AA^{3}$

8

$1.111 \mathrm{Mg} / \mathrm{m}^{3}$

$0.086 \mathrm{~mm}^{-1}$

2592

$3.53-22.53^{\circ}$

$-19 \leq h \leq 19,-2 \leq k \leq 13,-1 \leq l \leq 34$

9366

$9365[R(\mathrm{int})=0.0930]$

Full-matrix least-squares on $F^{2}$

9365 / 0 / 814

1.152

$R 1=0.0743, w R 2=0.1910$

$R 1=0.1144, w R 2=0.2122$

0.300 and $-0.297 \mathrm{e} \cdot \AA^{-3}$ 
Table CD9. Crystal data and structure refinement for $14 \cdot \mathrm{C}_{5} \mathrm{H}_{12}$.

Empirical formula

Formula weight

Temperature

Wavelength

Crystal system

Space group

Unit cell dimensions

Volume

Z

Calculated density

Absorption coefficient

$F(000)$

$\theta$ range for data collection

Index ranges

Reflections collected

Independent reflections

Refinement method

Data / restraints / parameters

Goodness-of-fit on $F^{2}$

Final $R$ indices $[I>2 \sigma(I)]$

$R$ indices (all data)

Largest difference peak and hole
$\mathrm{C}_{63} \mathrm{H}_{94} \mathrm{Al}_{2} \mathrm{~N}_{4} \mathrm{P}_{4}$

1085.26

133(2) K

$0.71073 \AA$

Orthorhombic

$P 2{ }_{1} / n$

$a=13.8751(7) \AA$

$b=14.3627(8) \AA$

$c=31.8580(16) \AA$

6348.8(6) $\AA^{3}$

4

$1.135 \mathrm{Mg} / \mathrm{m}^{3}$

$0.186 \mathrm{~mm}^{-1}$

2344

$1.28-22.63^{\circ}$

$-12 \leq h \leq 14,-15 \leq k \leq 15,-34 \leq l \leq 34$

25400

$8387[R($ int $)=0.0983]$

Full-matrix least-squares on $F^{2}$

8387 / 0 / 652

1.063

$R 1=0.0618, w R 2=0.1372$

$R 1=0.0847, w R 2=0.1490$

0.491 and $-0.410 \mathrm{e} \cdot \AA^{-3}$ 
Table CD10. Crystal data and structure refinement for $15 \cdot 2 \mathrm{C}_{7} \mathrm{H}_{8}$.

Empirical formula

Formula weight

Temperature

Wavelength

Crystal system

Space group

Unit cell dimensions

Volume

Z

Calculated density

Absorption coefficient

$F(000)$

$\theta$ range for data collection

Index ranges

Reflections collected

Independent reflections

Refinement method

Data / restraints / parameters

Goodness-of-fit on $F^{2}$

Final $R$ indices $[I>2 \sigma(I)]$

$R$ indices (all data)

Largest difference peak and hole
$\mathrm{C}_{72} \mathrm{H}_{98} \mathrm{Al}_{2} \mathrm{~N}_{4} \mathrm{~S}_{6}$

1265.86

100(2)

$1.54178 \AA$

Monoclinic

$P 2_{1} / n$

$a=14.277(1) \AA$

$b=16.387(1) \AA, \beta=109.66(1)^{\circ}$

$c=15.786(1) \AA$

3478(1) $\AA^{3}$

2

$1.209 \mathrm{Mg} / \mathrm{m}^{3}$

$2.386 \mathrm{~mm}^{-1}$

1360

$3.62-58.92^{\circ}$

$-15 \leq h \leq 14,-17 \leq k \leq 16,-17 \leq l \leq 17$

15352

$4907[R($ int $)=0.0363]$

Full-matrix least-squares on $F^{2}$

4907 / 0 / 394

1.050

$R 1=0.0328, w R 2=0.0836$

$R 1=0.0385, w R 2=0.0868$

0.619 and $-0.263 \mathrm{e} \cdot \AA^{-3}$ 


\section{References}

1. (a) W. Hallwachs, A. Schafarik, Liebigs Ann. Chem. 1859, 109, 206-209; (b) G. Wilke, Liebigs Ann. Chem. 1975, 805-833, and references therein; (c) J. J. Eisch, “Comprehensive Organometallic Chemistry II', Vol. 1, E. W. Abel, F. G. A. Stone, G. Wilkinson, Eds.; Pergamon, Oxford, 1995, p431.

2. (a) Cationic Polymerisations: Mechanisms, Synthesis and Applications, K. Matyjaszewski, Ed.; Marcel Dekker, New York, 1996; (b) M. Bochmann, D. M. Dawson, Angew. Chem. 1996, 108, 2371-2373; Angew. Chem. Int. Ed. Engl 1996, 35, 2226-2228; (c) M. Kuroki, T. Aida, S. Inoue, J. Am. Chem. Soc. 1987, 109, 4737-4738; (d) M. Kuroki, T. Watanabe, T. Aida, S. Inoue, J. Am. Chem. Soc. 1991, 113, 5903-5904; (e) D. Mardare, K. Matyjaszewski, S. Coca, Macromol. Rapid Commun. 1994, 15, 37-44; (f) J. A. Jegier, D. A. Atwood, Inorg. Chem. 1997, 36, 2034-2039; (g) R. M. Waymouth, Chem. Rev. 1998, 98, 25872598; (h) J. Skupinska, Chem. Rev. 1991, 91, 613-648.

3. (a) C. Wang, S. Friedrich, T. R. Younkin, R. T. Li, R. H. Grubbs, D. A. Bansleben, M. W. Day, Organometallics 1998, 17, 3149-3151; (b) D. J. Jones, V. C. Gibson, S. M. Green, P. J. Maddox, Chem. Commun. 2002, 1038-1039; (c) R. K. O’Reilly, V. C. Gibson, A. J. P. White, D. J. Williams, J. Am Chem. Soc. 2003, 125, 8450-8451.

4. (a) V. C. Gibson, S. Mastroianni, C. Newton, C. Redshaw, G. A. Solan, A. J. P. White, D. J. Williams, J. Chem. Soc., Dalton Trans. 2000, 1969-1971; (b) D. J. H. Emslie, W. E. Piers, R. MacDonald, J. Chem. Soc., Dalton Trans. 2002, 293-294; (c) D. J. H. Emslie, W. E. Piers, M. Parvez, J. Chem. Soc., Dalton Trans. 2003, 2615-2620; (d) S. Matsui, M. Mitani, J. Saito, Y. Tohi, H. Makio, N. Matsukawa, Y. Takagi, K. Tsure, M. Nitabaru, T. Nakano, 
H. Tanaka, N. Kashiwa, T. Fujita, J. Am. Chem. Soc. 2001, 123, 6847-6856.

5. (a) P. A. Cameron, V. C. Gibson, C. Redshaw, J. A. Segal, G. A. Solan, A. J. P. White, D. J. Williams, J. Chem. Soc., Dalton Trans. 2001, 1472-1476; (b) D. Pappalardo, C. Tedesco, C. Pellecchia, Eur. J. Inorg. Chem. 2002, 621-628; (c) M. S. Hill, A. R. Hutchison, T. S. Keizer, S. Parkin, M. A. VanAelstyn, D. A. Atwood, J. Organomet. Chem. 2001, 628, 71-75; (d) P. A. Cameron, V. C. Gibson, C. Redshaw, J. A. Segal, M. D. Bruce, A. J. P. White, D. A. Williams, Chem. Commun. 1999, 1883-1884; (e) P. A. Cameron, V. C. Gibson, C. Redshaw, J. A. Segal, A. J. P. White, D. J. Williams, J. Chem. Soc., Dalton Trans. 2002, 415-422.

6. (a) H. Sinn, W. Kaminsky, H.-J. Vollmer, R. Woldt, Angew. Chem. 1980, 92, 396-398; Angew. Chem. Int. Ed. Engl. 1980, 19, 390-392; (b) H. Sinn, W. Kaminsky, Adv. Organomet. Chem. 1980, 18, 99-149; (c) W. Kaminsky, R. Steiger, Polyhedron 1988, 7 , 2375-2381; (d) L. Resconi, F. Piemontesi, G. Franciscono, L. Abis, T. Fiorani, J. Am. Chem. Soc. 1992, 114, 1025-1032; (e) C. Sishta, R. M. Hathorn, T. J. Marks, J. Am. Chem. Soc. 1992, 114, 1112-1114.

7. (a) S. I. Ishida, J. Polym. Sci. 1962, 62, 1-14; (b) A. Storr, K. Jones, A. W. Laubengayer, J. Am. Chem. Soc. 1968, 90, 3173-3177.

8. (a) K. Ziegler, F. Krupp, K. Weyer, W. Larbig, Liebigs Ann. Chem. 1960, 629, 251-256; (b) N. Ueyama, T. Araki, H. Tani, Inorg. Chem. 1973, 12, 2218-2225; (c) J. L. Atwood, D. C. Hrncir, R. D. Priester, R. D. Rogers, Organometallics 1983, 2, 985-989.

9. (a) R. J. Wehmschulte, P. P. Power, J. Am. Chem. Soc. 1997, 119, 8387-8388; (b) J. Storre, A. Klemp, H. W. Roesky, H.-G. Schmidt, M. Noltemeyer, R. Fleischer, D. Stalke, J. Am. 
Chem. Soc. 1996, 118, 1380-1386; (c) M. R. Mason, J. M. Smith, S. G. Bott, A. R. Barron, J. Am. Chem. Soc. 1993, 115, 4971-4984.

10. (a) W. Zheng, N. C. Mösch-Zanetti, H. W. Roesky, M. Noltemeyer, M. Hewitt, H.-G. Schmidt, T. R. Schneider, Angew. Chem. 2000, 112, 4446-4448; Angew. Chem. Int. Ed. 2000, 39, 4276-4278; (b) W. Zheng, H. W. Roesky, M. Noltemeyer, Organometallics 2001, 20, 1033-1035.

11. H. W. Roesky, M. G. Walawalkar, R. Murugavel, Acc. Chem. Res. 2001, 34, 201-211. 12. (a) G. Bai, Y. Peng, H. W. Roesky, J. Li, H.-G. Schmidt, M. Noltemeyer, Angew. Chem. 2003, 115, 1164-1167; Angew. Chem. Int. Ed. 2003, 42, 1132-1135; (b) G. Bai, H. W. Roesky, J. Li, H.-G. Schmidt, M. Noltemeyer, Angew. Chem. 2003, 115, 5660-5664; Angew. Chem. Int. Ed. 2003, 42, 5502-5506.

13. V. Jancik, L. W. Pineda, J. Pinkas, H. W. Roesky, D. Neculai, A. M. Neculai, R. Herbst-Irmer, Angew. Chem. 2004, 116, 2194-2197; Angew. Chem. Int. Ed. 2004, 43, 2142-2145.

14. L. W. Pineda, V. Jancik, H. W. Roesky, D. Neculai, A. M. Neculai, Angew. Chem. 2004, 116, 1443-1445; Angew. Chem. Int. Ed. 2004, 43, 1419-1421.

15. C. J. Harlan, M. R. Mason, A. R. Barron, Organometallics 1994, 13, 2957-2969.

16. (a) F. J. M. Haussonne, Mater. Manuf. Processes 1995, 10, 717-755; (b) L.V. Interrante, Gov. Rep. Announce. Index (U. S.) 1995, 95, Abstr. No. 508364 (CAS: 1996, 124, 41 572); (c) L. V. Interrante, Gov. Rep. Announce. Index (U. S.) 1993, 93, Abstr. No. 350504 (CAS: 1994, 121, 89 550); (d) J. A. Jensen, U. S. Patent, 1994, US 5276105 (CAS: 1994, 120, 165306 ). 
17. M. P. Paradisi, G. P. Zecchini, Tetrahedron 1981, 37, 971-975.

18. J. E. Park, B.-J. Bae, Y. Kim, J. T. Park, I.-H. Suh, Organometallics 1999, 18, 1059-1067.

19. (a) C. Cui, H. W. Roesky, H. Hao, H.-G. Schmidt, M. Noltemeyer, Angew. Chem. 2000, 112, 1885-1887; Angew. Chem. Int. Ed. 2000, 39, 1815-1817; (b) H. Zhu, J. Chai, H. W. Roesky, M. Noltemeyer, H.-G. Schmidt, D. Vidovic, J. Magull, Eur. J. Inorg. Chem. 2003, 3113-3119.

20. (a) W. Zheng, A. Stasch, J. Prust, H. W. Roesky, F. Cimpoesu, M. Noltemeyer, H.-G. Schmidt, Angew. Chem. 2001, 113, 3569-3572; Angew. Chem. Int. Ed. 2001, 40, 3461-3464; (b) N. D. Reddy, H. W. Roesky, M. Noltemeyer, H.-G. Schmidt, Inorg. Chem. 2002, 41, 2374-2378; (c) A. Stasch, M. Ferbinteanu, J. Prust, W. Zheng, F. Cimpoesu, H. W. Roesky, J. Magull, H.-G. Schmidt, M. Noltemeyer, J. Am. Chem. Soc. 2002, 124, $5441-5448$.

21. (a) M. Cesari, G. Perego, G. Del Piero, S. Cucinella, E. Cernia, J. Organomet. Chem. 1974, 78, 203-213; (b) H. Nöth, P. Wolfgardt, Z. Naturforsch. 1976, B31, 697-708.

22. (a) G. Del Piero, M. Cesari, G. Perego, G. Dozzi, A. Mazzei, J. Organomet. Chem. 1977, 129, 281-288; (b) G. Del Piero, M. Cesari, G. Perego, S. Cucinella, E. Cernia, J. Organomet. Chem. 1977, 129, 289-298.

23. (a) "The Chemistry of Aluminum, Gallium, Indium and Thallium", A. J. Downs , Ed., Blackie, London, 1993; (b) J. D. Gorden, C. L. B. Macdonald, A. H. Cowley, Chem. Commun. 2001, 75-76; (c) G. S. Hair, A. H. Cowley, R. A. Jones, B. G. McBurnett, A. Voigt, J. Am. Chem. Soc. 1999, 121, 4922-4923. (d) M. Witt, H. W. Roesky, Curr. Sci. 2000, 78, 410-430. 
24. C. Dohmeier, C. Robl, M. Tacke, H. Schnöckel, Angew. Chem. 1991, 103, 594-595; Angew. Chem. Int. Ed. Engl. 1991, 30, 564-565.

25. (a) J. Gauss, U. Schneider, R. Ahlrichs, C. Dohmeier, H. Schnöckel, J. Am. Chem. Soc. 1993, 115, 2402-2408; (b) A. Haaland, K.-G. Martinsen, S. A. Shlykov, H. V. Volden, C. Dohmeier, H. Schnöckel, Organometallics 1995, 14, 3116-3119.

26. M. N. S. Rao, H. W. Roesky, G. Anantharaman, J. Organomet. Chem. 2002, 646, 4-14.

27. C. Dohmeier, D. Loos, H. Schnöckel, Angew. Chem. 1996, 108, 141-161; Angew. Chem. Int. Ed. Engl. 1996, 35, 129-149.

28. C. Dohmeier, H. Schnöckel, C. Robl, U. Schneider, R. Ahlrichs, Angew. Chem. 1994, 106, 225-226; Angew. Chem. Int. Ed. Engl. 1994, 33, 199-200.

29. S. Schulz, H. W. Roesky, H. J. Koch, G. M. Sheldrick, D. Stalke, A. Kuhn, Angew. Chem. 1993, 105, 1828-1830; Angew. Chem. Int. Ed. Engl. 1993, 32, 1729-1731.

30. S. Schulz, L. Häming, R. Herbst-Irmer, H. W. Roesky, G. M. Sheldrick, Angew. Chem. 1994, 106, 1052-1053; Angew. Chem. Int. Ed. Engl. 1994, 33, 969-970.

31. C. Cui, H. W. Roesky, H.-G. Schmidt, M. Noltemeyer, H. Hao, F. Cimpoesu, Angew. Chem. 2000, 112, 4444-4446; Angew. Chem. Int. Ed. 2000, 39, 4274-4276.

32. C. Cui, H. W. Roesky, H. G. Schmidt, M Noltemeyer, Angew. Chem. 2000, 112, 4705-4707; Angew. Chem. Int. Ed. 2000, 39, 4531-4533.

33. (a) H. Zhu, J. Chai, V. Chandrasekhar, H. W. Roesky, J. Magull, D. Vidovic, H.-G. Schmidt, M. Noltemeyer, P. P. Power, W. A. Merrill, J. Am. Chem. Soc. 2004, 126, 9472-9473; (b) H. Zhu, J. Chai, A. Stasch, H. W. Roesky, T. Blunck, D. Vidovic, J. Magull, H.-G. Schmidt, M. Noltemeyer, Eur. J. Inorg. Chem. accepted. 
34. Reviews: (a) M. B. Power, A. R. Barron, D. Hnyk, H. E. Robertson, D. W. H. Rankin, Adv. Mater. Optics Electron. 1995, 5, 177-185; (b) J. L. Atwood in Coordination Chemistry of Aluminum (Ed.: G. H. Robinson), VCH, New York, 1993, pp.197-232.

35. (a) H. Zhu, J. Chai, H. W. Roesky, M. Noltemeyer, H.-G. Schmidt, D. Vidovic, J. Magull, Eur. J. Inorg. Chem. 2003, 3113-3119, and references therein; (b) V. Jancik, M. M. Moya Cabrera, H. W. Roesky, R. Herbst-Irmer, D. Neculai, A. M. Neculai, M. Noltemeyer, H.-G. Schmidt, Eur. J. Inorg. Chem., 2004, 3508-3512; (c) J. E. Huheey, E. A. Keiter, R. L. Keiter, Inorganic Chemistry: Principles of Structure and Reactivity, 4th ed., Harper Collins College Publishers, New York, 1993, p.292; (d) P. D. Godfrey, C. L. Raston, B. W. Skelton, V.-A. Tolhurst, A. H. White, Chem. Commun. 1997, 2235-2236.

36. V. Jancik, Y. Peng, H. W. Roesky, J. Li, D. Neculai, A. M. Neculai, R. Herbst-Irmer, J. Am. Chem. Soc. 2003, 125, 1452-1453.

37. (a) M. Pickel, T. Casper, A. Rahm, C. Dambouwy and P. Chen, Helv. Chim. Acta, 2002, 12, 4337-4352; (b) D. Zhang, G.-X. Jin, L.-H. Weng and F. Wang, Organometallics, 2004, 23, 3270-3275.

38. R. A. Kovar, J. O. Callaway, Inorg. Synth. 1977, 17, 36-42.

39. S. Cucinella, A. Mazzei, W. Marconi, Inorg. Chim. Acta Rev. 1970, 4, 51-71.

40. (a) J. Storre, A. Klemp, H. W. Roesky, H.-G. Schmidt, M. Noltemeyer, R. Fleischer, D. Stalke, J. Am. Chem. Soc. 1997, 119, 7505-7513; (b) A. Bondi, J. Phys. Chem., 1964, 68, 441-452.

41. Y. Koide, A. R. Barron, Organometallics 1995, 14, 4026-4029.

42. C. N. McMahon, A. R. Barron, J. Chem. Soc., Dalton Trans. 1998, 3703-3704. 
43. B. Qian, D. L. Ward, M. R. Smith, III, Organometallics 1998, 17, 3070-3076.

44. J. P. Perdew, Phys. Rev. B, 1986, 33, 8822-8824.

45. R. Ahlrichs, M. Bär, H.-P. Baron, R. Bauernschmitt, S. Böcker, P. Deglmann, M. Ehrig, K. Eichkorn, S. Elliott, F. Furche, F. Haase, M. Häser, H. Horn, C. Hättig, C. Huber, U. Huniar, M. Katannek, A. Köhn, C. Kölmel, M. Kollwitz, K. May, C. Ochsenfeld, H. Öhm, A. Schäfer, U. Schneider, M. Sie, TURBOMOLE 5.5, University of Karlsruhe, Germany, 2002.

46. J. E. Huheey, E. A. Keiter, R. L. Keiter, Inorganic Chemistry: Principle of Structure and Reactivity 4th ed. Harper Collins College Publishers, New York, 1993, p.301, Table 8.4.

47. (a) G. H. Robinson, Ed., Coordination Chemistry of Aluminum, VCH Publishers; Weinheim, FRG, 1994, pp.1-56; (b) G. H. Robinson, Ed., Coordination Chemistry of Aluminum, VCH Publishers; Weinheim, FRG, 1994, pp.57-84; (c) A. Haaland, Angew. Chem. 1989, 101, 1017-1032; Angew. Chem. Int. Ed. Engl. 1989, 28, 992-1007.

48. P. B. Hitchcock, G. M. McLaughlin, J. D. Smith, K. M. Thomas, J. Chem. Soc., Chem. Commun. 1973, 934-935.

49. P. B. Hitchcock, J. D. Smith, K. M. Thomas, J. Chem. Soc., Dalton Trans. 1976, 1433-1437, and references therein.

50. K. Gosling, J. D. Smith, D. H. W. Wharmby, J. Chem. Soc. (A) 1969, 1738-1742.

51. S. Amirkhalili, P. B. Hitchcock, J. D. Smith, J. Chem. Soc., Dalton Trans. 1979, 1206-1212.

52. (a) D. A. Atwood, B. C. Yaerwood, J. Organomet. Chem. 2000, 600, 186-197; (b) K. Ziegler, E. Holzkamp, R. Köster, H. Lehmkuhl, Angew. Chem. 1955, 67, 213-214; (c) J. 
Weidlein, J. Organomet. Chem. 1973, 43, 257-286; (d) B. R. Jagirdar, E. F. Murphy, H. W. Roesky, Prog. Inorg. Chem. 1999, 48, 351-455.

53. (a) C. Cui, H. W. Roesky, M. Noltemeyer, M. F. Lappert, H.-G. Schmidt, H. Hao,

Organometallics 1999, 18, 2256-2261; (b) H. Hatop, H. W. Roesky, T. Labahn, C. Röpken, G. M. Sheldrick, M. Bhattacharjee, Organometallics 1998, 17, 4326-4328.

54. C. Schnitter, K. Klimek, H. W. Roesky, T. Albers, H.-G. Schmidt, C. Röpken, E. Parisini, Organometallics 1998, 17, 2249-2257.

55. S. D. Waezsada, F.-Q. Liu, E. F. Murphy, H. W. Roesky, M. Teichert, I. Usón, H.-G. Schmidt, T. Albers, E. Parisini, M. Noltemeyer, Organometallics 1997, 16, 1260-1264. 56. (a) H. Wessel. H.-S. Park, P. Müller, H. W. Roesky, I. Usón, Angew. Chem. 1999, 111, 850-852; Angew. Chem. Int. Ed. 1999, 38, 813-815; (b) G. Gundersen, T. Haugen, A. Haaland, J. Organomet. Chem. 1973, 54, 77-86.

57. (a) H. Hatop, M. Schiefer, H. W. Roesky, R. Herbst-Irmer, T. Labahn, Organometallics 2001, 20, 2643-2646, and references therein; (b) A. G. Avent, W.-Y. Chen, C. Eaborn, I. B. Gorrell, P. B. Hitchcock, J. D. Smith, Organometallics 1996, 15, 4343-4345; (c) P. Yu, P. Müller, M. A. Said, H. W. Roesky, I. Usón, G. Bai, M. Noltemeyer, Organometallics 1999, 18, 1669-1674; (d) H. Wessel, C. Rennekamp, H. W. Roesky, M. L. Montero, P. Müller, I. Usón, Organometallics 1998, 17, 1919-1921.

58. D. Chakraborty, S. Horchler, H. W. Roesky, M. Noltemeyer, H.-G. Schmidt, Inorg. Chem. 2000, 39, 3995-3998.

59. H. W. Roesky, A. Stasch, H. Hatop, C. Rennekamp, D. H. Hamilton, M. Noltemeyer, H.-G. Schmidt, Angew. Chem. 2000, 112, 177-179; Angew. Chem. Int. Ed. 2000, 39, 171-173. 
60. M. Ferbinteanu, H. W. Roesky, F. Cimpoesu, M. Atanasov, S. Köpke, R. Herbst-Irmer, Inorg. Chem. 2001, 40, 4947-4955.

61. (a) M. G. Gardiner, G. A. Koutsantonis, S. M. Lawrence, F.-C. Lee, C. L. Raston, Chem. Ber. 1996, 129, 545-549; (b) C. Jones, F.-C. Lee, G. A. Koutsantonis, M. G. Gardiner, C. L. Raston, J. Chem. Soc., Dalton Trans. 1996, 829-833.

62. C. Schnitter, S. D. Waezsada, H. W. Roesky, M. Teichert, I. Usón, E. Parisini, Organometallics 1997, 16, 1197-1202.

63. T. R. McDonald, W. S. McDonald, Acta Cryst. 1972, B28, 1619-1622.

64. A.-A.I. Al-Wassil, P. B. Hitchcock, S. Sarisaban, J. D. Smith, C. L. Wilson, J. Chem. Soc., Dalton Trans. 1985, 1929-1934.

65. J. I. Jones, W. S. McDonald, Proc. Chem. Soc. 1962, 366-367.

66. (a) M. Rahim, N. J. Taylor, S. Xin, Organometallics 1998, 17, 1315-1323; (b) K. Ziegler, H.-G. Gellert, K. Zosel, E. Holzkamp, J. Schneider, M. Söll, W.-R. Kroll, Liebigs Ann. Chem. 1960, 629, 121-166; (c) H. Martin, H. Bretinger, Makromol. Chem. 1992, 193, 1283-1288; (d) J. S. Kim, L. M. Wojcinski II, S. Liu, J. C. Sworen, A. Sen, J. Am. Chem. Soc. 2000, 122, 5668-5669.

67. H.-J. Cristau, Chem. Rev. 1994, 94, 1299-1313.

68. G. O. Spessard, G. L. Miessler, Organometallic Chemistry, Prentice Hall, Upper Saddle River, NJ, 1996, p.131.

69. Reviews: (a) M. Ehses, A. Romerosa, M. Peruzzini, Top. Curr. Chem. 2002, 220, 107-140; (b) O. J. Scherer, Angew. Chem. 1990, 102, 1137-1155; Angew. Chem. Int. Ed. Engl. 1990, 29, 1104-1122; (c) M. Scheer, E. Herrmann, Z. Chem. 1990, 29, 41-55; (d) O. J. Scherer, 
in Multiple Bonds and Low Coordination in Phosphorus Chemistry (Eds.: M. Regitz, O. J.

Scherer), G. Thieme, Stuttgart, FRG, 1990, Chapter 3; (e) K. H. Whitmire, Adv.

Organomet. Chem. 1998, 42, 1-145; (f) O. J. Scherer, Acc. Chem. Res. 1999, 32, 751-762.

70. O. J. Scherer, M. Swarowsky, G. Wolmershäuser, Organometallics 1989, 8, 841-842.

71. (a) W. Uhl, M. Benter, Chem. Commun. 1999, 771-772; (b) M. B. Power, A. R. Barron, Angew. Chem. 1991, 103, 1403-1404; Angew. Chem. Int. Ed. Engl. 1991, 30, 1353-1354.

72. M. A. Petrie, P. P. Power, Inorg. Chem. 1993, 32, 1309-1312, and references therein.

73. A. H. Cowley, R. A. Jones, Angew. Chem. 1989, 101, 1235-1242; Angew. Chem. Int. Ed. Engl. 1989, 28, 1208-1215.

74. C. Cui, S. Köpke, R. Herbst-Irmer, H. W. Roesky, M. Noltemeyer, H.-G. Schmidt, B. Wrackmeyer, J. Am. Chem. Soc. 2001, 123, 9091-9098.

75. The calculation was done on the level RI-MP2/TZVPP in TURBOMOLE.

76. Reviews: (a) N. Takeda, N. Tokitoh, R. Okazaki, Top Curr. Chem. 2003, 231, 153-202; (b) M. Draganjac, T. B. Rauchfuss, Angew. Chem.1985, 97, 745-760; Angew. Chem. Int. Ed. Engl. 1985, 24, 742-757; (c) D. Coucouvanis, Adv. Inorg. Chem. 1998, 45, 1-73; (d) R. Okazaki, Phosphorus, Sulfur, and Silicon 2001, 168-169, 41-50; (e) M. R. Dubois, Chem. Rev. 1989, 89, 1-9; (f) C. Sinonnet-Jégat, F. Sécheresse, Chem. Rev. 2001, 101, 2601-2611; (g) A. Müller, W. Jaegermann, J. H. Enemark, Coord. Chem. Rev. 1982, 46, 245-280; (h) J. W. Kolis, Coord. Chem. Rev. 1990, 105, 195-219; (i) A. Müller, Polyhedron 1986, 5 , 323-340; (j) A. Müller, E. Diemann, R. Jostes, H. Bögge, Angew. Chem. 1981, 93, 957-977; Angew. Chem. Int. Ed. Engl. 1981, 20, 934-954; (k) D. Coucouvanis, A. Hadjikyriacou, M. Draganjac, M. G. Kanatzidis, O. Ileperuma, Polyhedron 1986, 5, 
349-356.

77. T. B. Rauchfuss, Inorg. Chem. 2004, 43, 14-26.

78. C. M. Bolinger, T. B. Rauchfuss, S. R. Wilson, J. Am. Chem. Soc. 1981, 103, 5620-5621.

79. J. Amarasekera, T. B. Rauchfuss, A. L. Rheingold, Inorg. Chem. 1987, 26, 2017-2018.

80. A. C. Gallacher, A. A. Pinkerton, Acta Crystallogr. 1993, C49, 125-126.

81. The residual electron density $0.619 \mathrm{e} \cdot \AA^{-3}$ can be explained by the presence of a higher homologue in the crystal (ca. $3 \%$ ). It can be refined as either $\mathrm{L}_{2} \mathrm{Al}_{2} \mathrm{~S}_{7}$ or $\mathrm{L}_{2} \mathrm{Al}_{2} \mathrm{~S}_{8}$. Due to the inversion center it cannot be distinguished between these two homologues. Although this disordered model shows good geometry and leads to a lower R value, the ordered model for $\mathbf{1 5}$ was used for the discussion and theoretical calculations.

82. D. F. Shriver, M. A. Drezdzon, The Manipulation of Air-Sensitive Compounds, $2^{\text {nd }}$ ed., McGraw-Hill, New York, 1969.

83. D. D. Perrin, W. L. F. Armarego, Purification of Laboratory Chemicals, $3^{\text {rd }}$ ed., Pergamon, London, 1988.

84. G. M. Sheldrick, "SHELXS-97, Program for Structure Solution”, Acta Crystallogr. Sect. A 1990, 46, 467-473.

85. G. M. Sheldrick, SHELXL-97, Program for Crystal Structure Refinement, Universität Göttingen, FRG, 1997.

86. E. Krause, Ber. Dtsch. Chem. Ges. 1918, 51, 1447-1456.

87. B. Hübler-Blank, M. Witt, H. W. Roesky, J. Chem. Educ. 1993, 70, 408-409. 


\section{Lebenslauf}

Name: $\quad$ Ying Peng

Geboren: $\quad$ Ji'an, Jiangxi, China, am 20. 06. 1973

Eltern: $\quad$ Zhuyao Peng, Ingenieur

Jinxiang Chen, Arbeiterin

Staatsangehörigkeit: chinesisch

Familienstand: $\quad$ verheiratet seit 30.04.2000

\section{Schulausbildung}

09/1980 - 06/1985: Grundschule in Ji' an, Jiangxi, China

09/1985 - 06/1992: Middle school und high school in Ji’an, Jiangxi, China

\section{Hochschulausbildung}

09/1992 - 07/1996: Studium der Chemie im Fachbereich Chemie für Lehramt der Universität, Nanchang, Jiangxi, China

07/1996: $\quad$ Bachelor of Science

09/1996 - 07/1997: Lehrer an der Middle School Nr. 3 in Ji' an, Jiangxi, China

09/1997 - 07/2000: Studium der Physikalischen Chemie am Fujuan Institute of Research on the Structure of matter, the Chinese Academy of Sciences, Fuzhou, Fujian, China

07/2000: $\quad$ Master of Science

10/2000 - 11/2000: Äquivalenzprüfung zum Diplomexamen - Fach Chemie 12/2000 - 10/2004: Anfertigung der Dissertation unter Anleitung von Prof. Dr. Dr. h. c. mult. H. W. Roesky am Institut für Anorganische Chemie der GeorgAugust-Universität zu Göttingen 